\title{
GCU
}

Glasgow Caledonian

University

University for the Common Good

\section{Atomic spectrometry update: review of advances in the analysis of clinical and biological materials, foods and beverages}

Taylor, Andrew; Day, Martin P; Hill, Sarah; Marshall, John; Patriarca, Marina; White, Mark

Published in:

Journal of Analytical Atomic Spectrometry

DOI:

10.1039/C4JA90001D

Publication date:

2014

Document Version

Publisher's PDF, also known as Version of record

Link to publication in ResearchOnline

Citation for published version (Harvard):

Taylor, A, Day, MP, Hill, S, Marshall, J, Patriarca, M \& White, M 2014, 'Atomic spectrometry update: review of advances in the analysis of clinical and biological materials, foods and beverages', Journal of Analytical Atomic Spectrometry, vol. 29, no. 3, pp. 386-426. https://doi.org/10.1039/C4JA90001D

\section{General rights}

Copyright and moral rights for the publications made accessible in the public portal are retained by the authors and/or other copyright owners and it is a condition of accessing publications that users recognise and abide by the legal requirements associated with these rights.

Take down policy

If you believe that this document breaches copyright please view our takedown policy at https://edshare.gcu.ac.uk/id/eprint/5179 for details

of how to contact us. 
Cite this: DOI: $10.1039 / \mathrm{c} 4 \mathrm{ja} 90001 \mathrm{~d}$

Received 2nd January 2014

Accepted 2nd January 2014

DOI: 10.1039/c4ja90001d

www.rsc.org/jaas

\section{Atomic spectrometry update: Review of advances in the analysis of clinical and biological materials, foods and beverages}

\author{
Andrew Taylor, ${ }^{\text {*a }}$ Martin P. Day, ${ }^{b}$ Sarah Hill, ${ }^{c}$ John Marshall, ${ }^{d}$ Marina Patriarca ${ }^{e}$ \\ and Mark White
}

$\begin{array}{ll}\text { 1 } & \text { Reviews } \\ 2 & \begin{array}{l}\text { Metrology, interlaboratory studies, reference mate- } \\ \text { rials and reference ranges }\end{array} \\ 3 & \text { Sample collection and preparation } \\ \text { 3.1 } & \text { Collection and storage } \\ \text { 3.2 } & \text { Digestion, extraction and preconcentration } \\ 4 & \text { Progress with analytical techniques } \\ \text { 4.1 } & \text { Mass spectrometry } \\ \text { 4.2 } & \text { Atomic absorption spectrometry } \\ \text { 4.3 } & \text { Atomic emission spectrometry and laser induced } \\ & \text { breakdown spectroscopy } \\ \text { 4.4 } & \text { Atomic fluorescence spectrometry and vapour gener- } \\ & \text { ation procedures } \\ \text { 4.5 } & \text { X-ray fluorescence spectrometry } \\ \text { 4.5.1 } & \text { In vivo XRF spectrometry } \\ \text { 4.5.2 } & \text { Quantitative analysis } \\ \text { 5. } & \text { Applications: Clinical and biological materials } \\ \text { 5.1 } & \text { Metallomics } \\ \text { 5.2 } & \text { Imaging: LA-ICP-MS and XRF spectrometry } \\ \text { 5.3 } & \text { Multielement applications } \\ \text { 5.3.1 } & \text { Biological fluids } \\ \text { 5.3.2 } & \text { Tissues, hair and nails } \\ \text { 5.4. } & \text { Progress for individual elements } \\ \text { 5.4.1 } & \text { Aluminium } \\ \text { 5.4.2 } & \text { Antimony } \\ \text { 5.4.3 } & \text { Arsenic } \\ \text { 5.4.4 } & \text { Chromium } \\ \text { 5.4.5 } & \text { Cobalt } \\ \text { 5.4.6 } & \text { Copper } \\ \text { 5.4.7 } & \text { Gallium and indium } \\ & \end{array}$

${ }^{a}$ Supra-regional Assay Service, Trace Element Laboratory, Faculty of Health and Medical Sciences, University of Surrey, Guildford, Surrey, GU2 7XH, UK. E-mail: A. Taylor@surrey.ac.uk

${ }^{b}$ The Australian Wine Research Institute, PO Box 197, Glen Osmond, SA 5064, Australia

${ }^{c} L G C$, Queens Road, Teddington, Middlesex, TW11 OLY, UK

${ }^{d}$ Glasgow Caledonian University, Cowcaddens Road, Glasgow, G4 OBA, UK

${ }^{e}$ Istituto Superiore di Sanità, Viale Regina Elena 299, 00161 Roma, Italy

${ }^{f}$ Health and Safety Laboratory, Harpur Hill, Buxton, Derbyshire, SK17 9JN, UK

$\begin{array}{ll}\text { 5.4.8 } & \text { Gold } \\ \text { 5.4.9 } & \text { Halides } \\ \text { 5.4.10 } & \text { Iron } \\ \text { 5.4.11 } & \text { Lead } \\ \text { 5.4.12 } & \text { Manganese } \\ \text { 5.4.13 } & \text { Mercury } \\ \text { 5.4.14 } & \text { Nickel } \\ \text { 5.4.15 } & \text { Platinum } \\ \mathbf{5 . 4 . 1 6} & \text { Rare earth elements } \\ \mathbf{5 . 4 . 1 7} & \text { Selenium } \\ \mathbf{5 . 3 . 1 8} & \text { Silver } \\ \mathbf{5 . 4 . 1 9} & \text { Strontium } \\ \mathbf{5 . 4 . 2 0} & \text { Tin } \\ \mathbf{5 . 4 . 2 1} & \text { Titanium } \\ \mathbf{5 . 4 . 2 2} & \text { Uranium } \\ \mathbf{5 . 4 . 2 3} & \text { Zinc }\end{array}$

6 Applications: Drugs and pharmaceuticals, traditional medicines and supplements

7 Applications: Foods and beverages

7.1 Progress for individual elements

7.1.1 Arsenic

7.1.2 Mercury

7.1.3 Selenium

7.1.4 Other elements

7.2 Single and multielement applications in food and beverages

7.2.1 Dietary intake studies

7.2.2 Human milk and infant formula

7.2.3 Milk and dairy products

7.2.4 Cereals, flour and rice

7.2.5 Vegetables, vegetable oils, fruits and nuts

7.5.6 Fish and seafood

7.2.7 Meat and offal

7.2.8 Drinking water and non-alcoholic beverages

7.2.9 Alcoholic beverages

This review includes publications from November 2012 to September 2013. Microfluidic devices are starting to appear in reports relevant to 
this ASU. Chip-based technologies were described, performing preparation steps, as also were liquid-liquid microextractions, which were mentioned last year. Another innovation involved an atomically imprinted polymer, used for pre-concentration of Se from foods, by an impressive factor of 232. Continuum source AAS is being used more and more with several applications reported for single element measurements but more usually for multi-element determinations. Associated with an increasing concern at the number of failures of metal implants, such as for hips, have been publications of methods for measuring metal ions in clinical samples and also reports of their concentrations in samples from healthy and affected patients. Events such as this draw attention to the importance of well-defined reference ranges and groups from Belgium and the UK measured a range of elements in urine specimens from large numbers of healthy adults. Concentrations for several elements were reported as undetectable so it is useful to see some workers addressing the challenge of reducing detection limits. New approaches to diagnosing Wilson's disease were suggested. It was proposed to measure ${ }^{65} \mathrm{Cu}:{ }^{63} \mathrm{Cu}$ ratios in serum and urine, but this is only feasible with access to a MC-ICPMS. Cystic fibrosis is usually diagnosed by determining the $\mathrm{Cl}^{-}$ concentration in sweat and it has been shown for the first time that this may be carried out using ICP-MS. It was shown that $\mathrm{Al}$ and $\mathrm{Br}$ in conventional tissue stains might be used to guide the distribution of other elements in cell structures, when determined by LA-ICPMS. A popular element for investigation at the moment appears to be silver. Partly this follows from increased use of silver nanoparticles and whether there might be any toxicity but also from where it is employed for its antibacterial properties, such as in dressings applied to large exposed wounds and in jug filters for drinking water purification.

\section{Reviews}

This latest Update adds to that from last year ${ }^{1}$ and complements other reviews of analytical techniques in the series of Atomic Spectrometry Updates from the last year..$^{2-6}$ In a follow-up to previous reviews, Kleparit described developments in CE and microfluidic devices used together with MS, as published between January 2010 and June 2012.7 Particular attention was directed to improvements with interfacing via ICP, ESI and matrix-assisted desorption/ionisation. To demonstrate the versatility of the techniques, applications such as proteomics, glycaemics, metabolomics, biomarker research, forensics, pharmacology, food analysis and single-cell analysis were described. Analyte enrichment is an essential step to measure very low concentrations of many metals in environmental, biological and food samples. In recent years, new solid phase sorbents have enhanced the range of available techniques for pre-concentration and carbon nanotube SPE has featured prominently among these developments. In a very helpful review, Latorre et al. ${ }^{8}$ gave a detailed discussion of adsorption, desorption and measurement of metals by quantitative atomic spectrometric techniques. Topics included synthesis, purification and functionalisation of different types of carbon nanotubes and how these afford improvements in analytical sensitivity and selectivity. Techniques that are usefully applied to studying Se metabolism in cancer cells were reviewed by Weekley et al. ${ }^{9}$ with particular emphasis on XAS and XFM. Lanni et al. ${ }^{10}$ took up the theme of MS imaging and profiling of single cells. Reference was made to SIMS and MALDI-MS noting the submicron level resolution achievable by the former. Applications using a number of other techniques were also included. The theme of dispersive liquid-liquid micro extraction procedures, which we noted in our last Update, ${ }^{1}$ was discussed in a review by Yan and Wang. ${ }^{11}$

The emphasis on metal-containing anti-cancer drug metabolism research has been on interactions with DNA. Developments with new sensitive and selective analytical techniques make possible work with other targets, such as proteins. Groessl and Hartinger ${ }^{12}$ discussed how these developments, together with proteomic screening and gene expression analysis, can inform responses to treatment, drug resistance and toxicity.

Human health issues related to exposure to metalloids were reviewed in some detail. McClintock et al. ${ }^{13}$ presented a review of exposure to, and health effects of, As. This was in the context of the situation in Latin America where it has been estimated that as many as 4.5 million people receive drinking water with concentrations of $50-200 \mu \mathrm{g} \mathrm{L} \mathrm{L}^{-1}$ (the WHO provisional standard is $\left.10 \mu \mathrm{g} \mathrm{L}^{-1}\right)$. The review, from 82 publications, pointed to elevated risks of numerous adverse health outcomes caused by chronic As exposure, including carcinogenicity, reproductive problems, and impaired childhood cognitive function. It was further noted that genetic polymorphisms can influence morbidity via modulation of As metabolism. In the third of a series of reviews of human exposure to Sb, Filella et al. ${ }^{14}$ presented data pertaining to concentrations of the element in urine, milk and saliva. The information included took account of concentrations reported, methodology of measurement and usefulness of data in assessing exposure. The authors noted limitations to many published studies such as failure to analyse CRMs and poor sensitivity of some of the techniques used. They concluded (i) that, while concentrations in urine will be less than $0.1 \mu \mathrm{g} \mathrm{L}^{-1}$, a reference interval for healthy unexposed individuals cannot be established and (ii) there are too few studies to infer anything concerning $\mathrm{Sb}$ in milk or saliva. Sunday et al. ${ }^{15}$ described the continuing problems associated with residues of organotin compounds in the marine environment, noting issues affecting mammals and shellfish and, by implication, humans also. Noting the many analytical methods developed for speciating organotin compounds, they reviewed both the analytical techniques and toxicity of these agents.

\section{Metrology, interlaboratory studies, reference materials and reference ranges}

Miyashita et al. ${ }^{16}$ described the preparation of a Brown Rice Flour CRM (NMIJ CRM 7531-a) by the Japanese NMI, which also assigned the certified concentrations for $\mathrm{As}, \mathrm{Cd}, \mathrm{Cu}, \mathrm{Fe}, \mathrm{Mn}$ and Zn using ICP-QMS, SF-ICP-MS, ID-ICP-MS, ICP-AES and ETAAS. The standard uncertainties for the homogeneity, characterisation, differences among analytical methods, dry-mass 
Table 1 Comparison of results ( $\mu \mathrm{g}$ g creatinine ${ }^{-1}$ ) from two reports of reference ranges for trace elements in urine. Values are $97.5^{\text {th }}$ and $95^{\text {th }}$ percentile for the Belgium and United Kingdom data, respectively ${ }^{a}$

\begin{tabular}{lcc}
\hline Element & Belgium & United \\
\hline $\mathrm{Al}$ & 8.54 & 13.88 \\
$\mathrm{As}$ & 231 & 511 \\
$\mathrm{Bi}$ & 0.05 & 0.18 \\
$\mathrm{Cd}$ & 0.64 & 1.98 \\
$\mathrm{Co}$ & 1.12 & 2.19 \\
$\mathrm{Cr}$ & 0.34 & 0.55 \\
$\mathrm{Cu}$ & 12.88 & 40.52 \\
$\mathrm{Hg}$ & 1.98 & 1.95 \\
$\mathrm{Mn}$ & 0.75 & 1.95 \\
$\mathrm{Ni}$ & 4.88 & 9.82 \\
$\mathrm{~Pb}$ & 2.61 & 6.05 \\
$\mathrm{Sb}$ & 0.20 & 0.56 \\
$\mathrm{Se}$ & 37.1 & 34.68 \\
$\mathrm{Zn}$ & 720 & 752
\end{tabular}

${ }^{a}$ Summaries of publications discussed in this review, together with other work not included in any detail are summarised in Table 2 and 3.

correction factor and calibration standard yielded combined standard uncertainties from 1.1\% for Zn to 1.6\% for As.

Two publications reported on the reference ranges for trace elements in urine specimens from healthy adult individuals, determined by ICP-MS. Both included full details of the sample collection, analytical procedures and quality assurance. Hoet et al. ${ }^{17}$ determined 26 elements in specimens from 1022 healthy Belgian adults. Information on smoking and recent consumption of fish/seafood was recorded and taken into account when reporting $\mathrm{Cd}$ and As, respectively. Results $(2.5,50$ and 97.5 percentiles) were given as $\mu \mathrm{g} \mathrm{L}^{-1}$ and as $\mu \mathrm{g}$ g creatinine ${ }^{-1}$. Significant differences between male and female subjects were commented on in the text. In addition to $\mathrm{Cd}$, concentrations of 9 other elements were significantly greater in specimens from smokers. From the UK, Sieniawska et al. ${ }^{18}$ measured 31 elements from 111 individuals and presented their results in molar units per $24 \mathrm{~h}$ and as the ratio per mmol of creatinine. The values were reported for all subjects and separately for males and females, expressed as the median, mean and $95^{\text {th }}$ percentile. Any effects of smoking and diet were not recorded. Both papers included calculations of the $95 \%$ coverage intervals. Direct comparison between these two data sets is not possible due to the way results were reported. After conversion of the UK $95^{\text {th }}$ percentile creatinine-corrected values to $\mu \mathrm{g} g$ creatinine $^{-1}$, differences were evident (Table 1) when placed alongside the Belgian $97.5^{\text {th }}$ percentile results, e.g., Cu. Nevertheless, both sets of results were said to be comparable with published work from other counties and provide valuable resources for other workers.

\section{Sample collection and preparation}

\subsection{Collection and storage}

Analysis of blood spotted onto filter paper is well established for neonatal screening and, less reliably, also for measuring concentrations of metals. In two publications from the
Department of Analytical Chemistry at the University of Zaragoza, the analysis of urine collected onto filter paper was described. ${ }^{19,20}$ As there is considerable spreading of the sample on drying there can be differential movement of metals and a small amount of urine per unit surface area. To address these drawbacks the workers added fixed amounts of urine onto precut filter paper. In one study, $500 \mu \mathrm{L}$ were spotted onto $17 \times$ $19 \mathrm{~mm}$ pieces of filter paper for measurement of Mo and Ti by solid sampling HR-CS-ETAAS. ${ }^{19}$ Matrix-matched calibration using urine was with known analyte concentrations, and CRMs were analysed to validate the methodology. It was proposed that the procedure could be used for regular monitoring of patients with metallic prostheses. For the second project, ${ }^{20} 300 \mu \mathrm{L}$ urine were spotted onto $16 \mathrm{~mm}$ filter paper circles to determine ${ }^{65} \mathrm{Cu}:{ }^{63} \mathrm{Cu}$ isotope ratios by fs-LA-MC-ICP-MS Readings were taken close to the rim, where concentrations were greatest. It was proposed that this application could be used to diagnose patients with Wilson's disease.

Zachariadis et al. ${ }^{21}$ investigated the stability of TBT in human urine and found that storage at 4 or $-20^{\circ} \mathrm{C}$ was possible for no more than 2 days. Thereafter, greater variation was seen in those maintained at $4{ }^{\circ} \mathrm{C}$ compared to $-20^{\circ} \mathrm{C}$. Losses were also noted following freeze-thaw cycles. Samples were analysed by GC-MS following ethylation and headspace solid phase microextraction.

\subsection{Digestion, extraction and pre-concentration}

A highly innovative approach to speciation of Se in Se-enriched yeast cells was developed by Chen $e t$ al. ${ }^{22}$ Solid phase extraction was accomplished on a microfluidic chip which incorporated sulfonated polystyrene-coated magnetic nanoparticles for reaction, mixing and extraction. Selenoamino acids and peptides in the samples were adsorbed by cation exchange interactions involving the sulfonic acid groups on the surface of the nanoparticles, and then separated from the matrix with a magnetic field. Removal of the field allowed redispersion in the eluent. The method was validated by analysis of SELM-1 yeast CRM, with measurement of Se by HPLC-ICP-MS.

A second novel pre-concentration method for determination of Se was reported by de Lima et al. ${ }^{23}$ The pre-concentration medium was described as an atomically imprinted polymer (AIP), a development from molecularly- and ion-imprinted polymers, which are synthetic materials with recesses specifically prepared to retain a molecule, ion or atom of interest. The polymer was prepared from 4 vinylpyridine, 1-vinylimidazole, ethylene glycol dimethacrylate and 2,2'-azobis-isobutyronitrile. The procedure involved the inclusion of $\mathrm{SeO}_{2}$ which, after incorporation into the polymer, was reduced to $\mathrm{Se}^{0}$ by addition of $\mathrm{MeOH}$, to form the Se-specific recess. The $\mathrm{Se}^{0}$ was removed by washing with hypochlorite thus leaving the imprinted polymer which was then dried, sieved and packed into a small column for inclusion in an FI system for HG-FAAS determination of Se in samples. All steps in the synthesis of the AIP and the determination of Se were investigated and optimised. The preconcentration factor was 232 and, with a trapping time of $4 \mathrm{~min}$ and sample flow rate of $3.5 \mathrm{~mL} \mathrm{~min}^{-1}$, gave an LOD of $53 \mathrm{ng} \mathrm{L}^{-1}$. 
Table 2 Clinical and biological materials (for column 3, L = liquid, S = solid, SI = slurry)

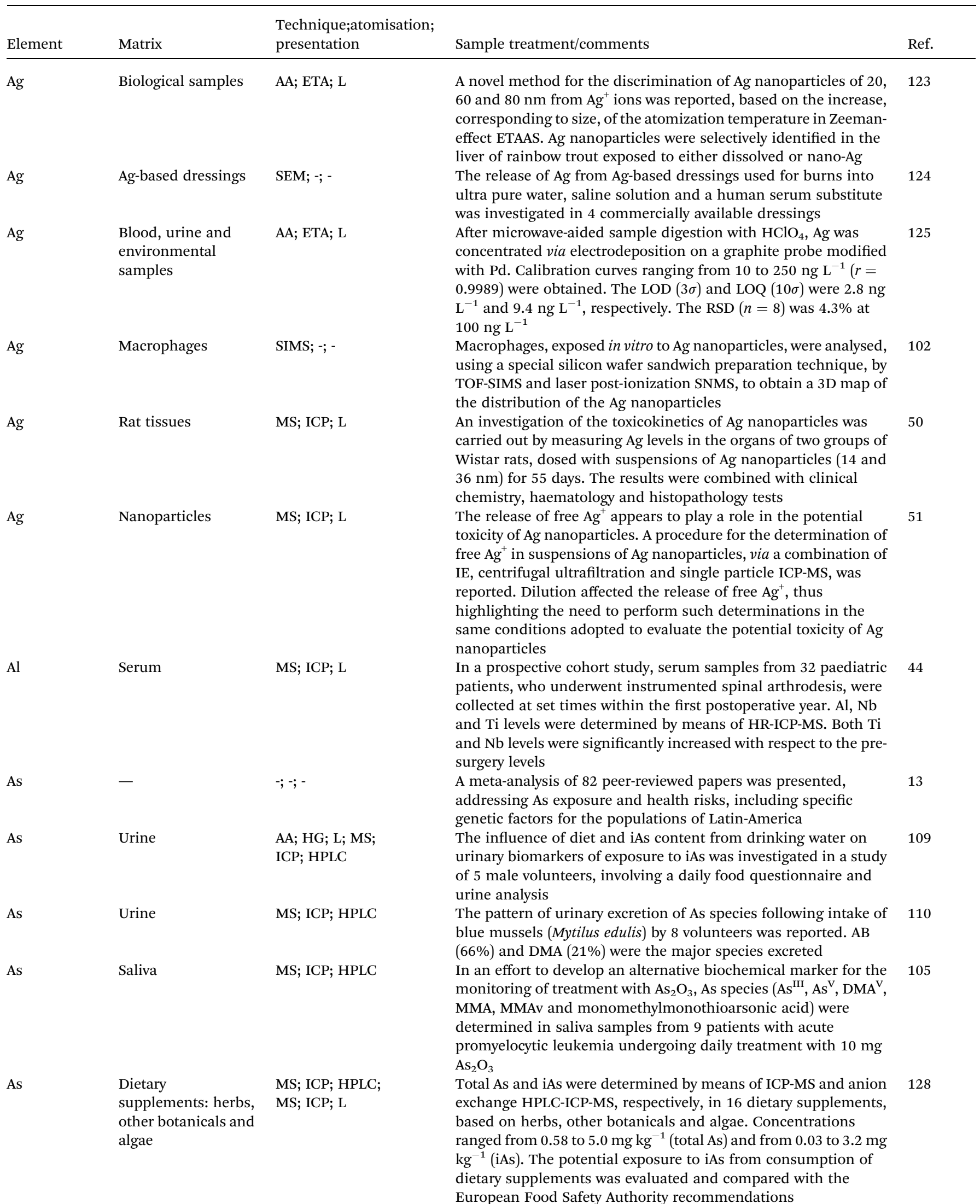


Table 2 (Contd.)

Technique;atomisation;

\begin{tabular}{lll} 
Element & Matrix & $\begin{array}{l}\text { presentation } \\
\text { As }\end{array}$ \\
\hline Human scalp hair & MS; ICP; HPLC;
\end{tabular}
a pressure of 1500 psi for 5 min in 4 extraction steps. Total As concentrations were determined by ICP-MS and those of As ${ }^{\mathrm{III}}$ and $\mathrm{As}^{\mathrm{V}}$ by HPLC-ICP-MS. The LOQs were 7.0, 6.3 and $50.3 \mathrm{ng} \mathrm{g}^{-1}$ for total As, $\mathrm{As}^{\mathrm{III}}$ and $\mathrm{As}^{\mathrm{V}}$, respectively. Repeatability RSDs were $4.4 \%$ (total As), 7.2\% (As ${ }^{\mathrm{III}}$ ) and $2.1 \%\left(\mathrm{As}^{\mathrm{V}}\right)$

$\mathrm{Au} \quad$ Tissues XRF; - -

Tissue samples, collected after sacrifice from BALB/c female mice treated with Au nanorods, were dissolved in a $20 \% \mathrm{w} / \mathrm{w} \mathrm{KOH}$ solution under continuous shaking for 4-6 h. A thin sample area was obtained by placing a $35 \mu \mathrm{L}$ aliquot in a sample cup and drying it for about $2 \mathrm{~h}$ at $30^{\circ} \mathrm{C}$ under vacuum. A calibration curve (0-50 ppm) was obtained analysing different types of tissue, spiked with $\mathrm{Au}\left(r^{2}=0.93\right)$. The LOD was $1.4 \mathrm{ppm}$. Interferences from $\mathrm{Zn}$ and $\mathrm{Br}$ were observed, the latter due to the use of 2-2-2tribromoethanol for the anesthesia. Au levels in the experimental mouse tumour samples were between 5.8 and $41.3 \mathrm{ppm}$

$\mathrm{Ba}$

Blood, urine

Pharmaceutical ingredients

$\mathrm{Cl}$

Co

Co

Co

Co

Co

Serum
Blood, plasma and urine

Blood

Serum

MS; ICP; L

MS; ICP; L

MS; ICP; L
AE; ICP; L

MS; ICP; L

MS; ICP; L

MS; ICP; L

MS; ICP; SEC

MS; ICP; L

MS; ICP; L in paralysis and heart disorders, Ba concentrations in blood and urine samples were measured by means of ICP-AES at 455.403 $\mathrm{nm}$, after microwave-aided digestion

For the determination of $\mathrm{Br}$ and I, sample digestion was performed in less than $30 \mathrm{~s}$ by microwave-induced combustion of $500 \mathrm{mg}$ of sample at an initial $\mathrm{O}_{2}$ pressure of 20 bars, leading to a C content $<500 \mathrm{mg} \mathrm{L}^{-1}$ in the final sample solution. Analysis of CRMs gave recoveries $>95 \%(\mathrm{Br})$ and $>97 \%$ (I). LODs were $0.02 \mu \mathrm{g}$ $\mathrm{g}^{-1}(\mathrm{Br})$ and $0.001 \mu \mathrm{g} \mathrm{g}^{-1}(\mathrm{I})$

A method for the simultaneous determination of $\mathrm{Cl}$ and $\mathrm{Na}$ in sweat samples was evaluated and applied to routine measurements to aid the diagnosis of cystic fibrosis. Sweat samples were diluted $1+100$ with $1 \% \mathrm{HNO}_{3}$ containing ${ }^{45} \mathrm{Sc}$ as the internal standard. Between-batch precision was $<3.4 \%(\mathrm{Cl})$ and $<3.7 \%(\mathrm{Na})$. Analysis of samples from the UK NEQAS Sweat Testing Scheme provided satisfactory results

A follow-up study of 163 patients who underwent total hip arthroplasty indicated that $\mathrm{Co}$ and $\mathrm{Cr}$ release in blood peaked between 4 and 5 years after operation

An extensive study of $\mathrm{Co}, \mathrm{Cr}$ and $\mathrm{Ni}$ concentrations in blood, plasma and urine was carried out to understand the distribution patterns and interactions of metals released from metal-on-metal arthroplasty

In a study of possible release of metal ions from metallic prosthesis, the possible contamination of blood samples during collection was investigated, using HR-ICP-MS

In a prospective longitudinal study, Co and Cr levels in serum samples from 24 patients with cobalt-chromium alloy metal-onmetal lumbar disc replacements were determined by means of HR-ICP-MS, with LODs of $0.04 \mathrm{ng} \mathrm{mL}^{-1}$ (Co) and $0.015 \mathrm{ng} \mathrm{mL}^{-1}$ (Cr)

Co species were separated according to $M_{\mathrm{r}}$ (high $M_{\mathrm{r}}$, e.g., Co bound to proteins; low $M_{\mathrm{r}}$, e.g., cyanocobalamin, glutathione-Co and free Co). The LOD was $0.037 \mu \mathrm{g} \mathrm{L}^{-1}$ in undiluted serum and recovery was $>91 \%$ with respect to total Co concentrations measured on acid digested samples. Speciation after Co supplementation, studied on 12 subjects, indicated that $96 \%$ of Co was bound to proteins $\left(M_{\mathrm{r}}>50 \mathrm{kDa}\right)$

See Co, ref. 39

In a cross-sectional study involving 11 children implanted with a metal bar to correct for pectum excavatum, increased serum levels were reported for $\mathrm{Cr}$ and $\mathrm{Ni}$, but not $\mathrm{Mo}$ 
Table 2 (Contd.)

\begin{tabular}{|c|c|c|}
\hline Element & Matrix & $\begin{array}{l}\text { Technique;aton } \\
\text { presentation }\end{array}$ \\
\hline $\mathrm{Cr}$ & $\begin{array}{l}\text { Blood, plasma and } \\
\text { urine }\end{array}$ & MS; ICP; L \\
\hline $\mathrm{Cr}$ & Blood & MS; ICP; L \\
\hline $\mathrm{Cr}$ & Blood, tissues & AA; ETA; \\
\hline $\mathrm{Cr}$ & Blood & MS; ICP; L \\
\hline $\mathrm{Cr}$ & $\begin{array}{l}\text { Pharmaceutical } \\
\text { formulations }\end{array}$ & AA; ETA; L \\
\hline $\mathrm{Cr}$ & Serum & MS; ICP; L \\
\hline $\mathrm{Cu}$ & Brain & MS; ICP; L \\
\hline $\mathrm{Cu}$ & Urine & MS; ICP; LA \\
\hline $\mathrm{Cu}$ & Serum & MS; ICP; HPLC \\
\hline $\mathrm{Eu}$ & Urine & AE; ICP; L \\
\hline $\mathrm{Fe}$ & $\begin{array}{l}\text { Faeces, urine, red } \\
\text { blood cells, serum, } \\
\text { liver, and kidney }\end{array}$ & MS; ICP; L \\
\hline $\mathrm{Fe}$ & Human milk & $\begin{array}{l}\text { MS; ICP; L; } \\
\text { MS; ICP; SEC }\end{array}$ \\
\hline $\mathrm{Fe}$ & Brain & TIMS; -; - \\
\hline $\mathrm{Ga}$ & $\begin{array}{l}\text { Urine, lake water, } \\
\text { CRMs }\end{array}$ & AE; ICP; L \\
\hline
\end{tabular}

Sample treatment/comments

See Co, ref. 40

Ref.

40

See Co, ref. 41

An investigation of optimum conditions for microwave-assisted sample digestion and the best modifier for the analytical determination was presented. A procedure using $5 \mu \mathrm{g} \mathrm{Mg}\left(\mathrm{NO}_{3}\right)_{2}$ and pyrolysis and atomization temperatures of 1400 and $2500{ }^{\circ} \mathrm{C}$, respectively, was chosen. Linearity ranged from 0.22 to $12.0 \mu \mathrm{g}$ $\mathrm{L}^{-1}$. The LOD and LOQ were $0.07 \mu \mathrm{g} \mathrm{L}^{-1}$ and $0.22 \mu \mathrm{g} \mathrm{L}^{-1}$, respectively, and the RSD was $<6 \%$. The analysis of CRMs gave results within $98.4 \%$ to $104.4 \%$ of the certified values and recovery of spiked samples ranged from $84.5 \%$ to $103.2 \%$ A reference interval of $3.92-7.48 \mathrm{nmol} \mathrm{L}^{-1}$ was established from a sample of 51 healthy adults (12 males, 39 females), aged 19-64 years. Blood samples were analysed by ICP-MS with a collision/ reaction cell using $\mathrm{He}$ as the collision gas. The reported accuracy of the method was between 87.7 and $99.8 \%$

Quantitative extraction of both $\mathrm{Cr}$ and $\mathrm{Mn}$ from sample aliquots between 25 - and $150 \mathrm{mg}$ in $5 \mathrm{~mL} 1 \mathrm{M} \mathrm{HCl}$ was achieved by treatment with focused ultrasound for $30 \mathrm{~min}$ at $50 \%$ power. Comparison with total digestion showed no statistical difference $(95 \%)$ in results

See Co, ref. 45

The distribution and cellular localization of $\mathrm{Cu}$ transport proteins in multiple regions of the human brain were investigated by using ICP-MS, Western blot and immunohistochemistry

The ${ }^{65} \mathrm{Cu}:{ }^{63} \mathrm{Cu}$ ratio was determined in dried urine spots by means of a $257 \mathrm{~nm}$ fs LA device coupled to MC-ICP-MS, as a potential screening tool for the diagnosis of Wilson's disease In spite of the developments in genetic testing and the availability of a $\mathrm{Cu}$ handling test, based on the stable ${ }^{65} \mathrm{Cu}$ as a tracer, the potential use of isotopic analysis of $\mathrm{Cu}$ in serum samples was investigated as a potential diagnostic aid for Wilson's disease Urinary excretion of Eu, Sc and Y in male Wistar rats dosed with chlorides of these elements was $<2 \%$

The metabolic pathways of Fe from formula milk were investigated experimentally in lactating rats by means of Fe stable isotopes $\left({ }^{54} \mathrm{Fe}\right.$ and $\left.{ }^{57} \mathrm{Fe}\right)$ as tracers

The Fe and Fe species content in human milk samples from preterm and full-term infants was determined and compared with that in commercial pre-term and full-term formulas

The uptake of Fe from the diet into the brain and other organs was investigated in adult rats using ${ }^{57} \mathrm{Fe}$ as a tracer

$\mathrm{Ga}$ and I were extracted after complexation with $1.7 \mathrm{mM} 5-\mathrm{Br}-$ PADAP in the presence of $1.3 \%(\mathrm{w} / \mathrm{v})$ Triton X-100 at pH 7.0 and $75{ }^{\circ} \mathrm{C}$. Analytical performance on the extracted samples gave RSDs between $0.3 \%$ and $1.6 \%$, linearity ranging from 6 to $200 \mathrm{ng} \mathrm{mL}^{-1}$ (Ga) and from 2 to $200 \mathrm{ng} \mathrm{mL}^{-1}$ (I) and LODs of $0.72 \mathrm{ng} \mathrm{mL}^{-1}(\mathrm{Ga})$ and $0.28 \mathrm{ng} \mathrm{mL}^{-1}$ (I). Recoveries were between $98 \%$ and $102 \%$ 489 samples of urinary calculi were analysed for their $\mathrm{Hg}$ content by thermo-oxidation CV-AAS. Median concentrations by age groups ranged from $0.060 \mathrm{mg} \mathrm{kg}^{-1}$ to $0.365 \mathrm{mg} \mathrm{kg}^{-1}$. The relationship with other elements was discussed

In a pilot investigation of new biomarkers of exposure to $\mathrm{MeHg}$, a sample treatment for nail clippings was developed, consisting of dissolution in TMAH, derivatisation of $\mathrm{MeHg}$ with sodium tetraethylborate and extraction into iso-octane, prior to determination of $\mathrm{MeHg}$ concentrations by GC-ICP-MS

A novel procedure for speciation of $\mathrm{Hg}$ species at the low levels occurring in terrestrial animal organs such as red deer liver, red deer kidney and wild boar kidney was developed and validated 
Table 2 (Contd.)

\begin{tabular}{|c|c|c|c|}
\hline Element & Matrix & $\begin{array}{l}\text { Technique; atomisation; } \\
\text { presentation }\end{array}$ & Sample treatment/comments \\
\hline $\mathrm{Hg}$ & Human milk & $\mathrm{AF} ;-;-$ & $\begin{array}{l}\text { The possibility of infant exposure to } \mathrm{Hg} \text { intake through lactation } \\
\text { was investigated by measuring } \mathrm{Hg} \text { concentrations in human milk } \\
\text { samples from } 18 \text { nursing mothers in Brazil and comparing them } \\
\text { with the frequency of fish consumption }\end{array}$ \\
\hline $\mathrm{Hg}$ & $\begin{array}{l}\text { Blood plasma, } \\
\text { serum }\end{array}$ & $\begin{array}{l}\text { MS; ICP/CV; } \\
\text { HPLC }\end{array}$ & 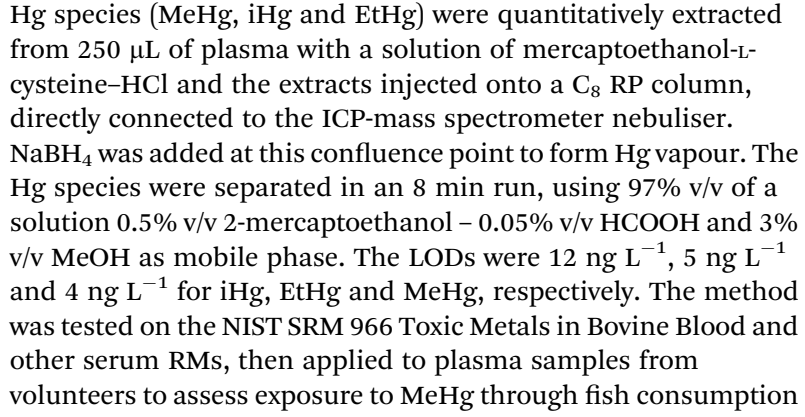 \\
\hline $\mathrm{Hg}$ & Biological samples & $\mathrm{AA} ; \mathrm{CV} ; \mathrm{L}$ & $\begin{array}{l}\text { As an alternative to microwave-assisted digestion, a novel } \\
\text { digestion system for biological samples was described, consisting } \\
\text { of a glass tube closed with a small glass tube filled with cold water } \\
\text { (the "cold finger"). The comparison of the proposed system } v s \text {. } \\
\text { open digestion, carried out on both aqueous solutions and CRMs, } \\
\text { at digestion temperatures between } 80 \text { and } 120^{\circ} \mathrm{C} \text {, supported the } \\
\text { improved performance of the new system with respect to losses of } \\
\mathrm{Hg} \text {. The LOD was } 0.08 \mu \mathrm{g} \mathrm{L} \mathrm{L}^{-1}\end{array}$ \\
\hline & Pharmaceutical & MS; ICP; L & See Br, ref. 35 \\
\hline
\end{tabular}

\section{ingredients}

In

Pharmaceutica formulations

Nails

\section{CRMs}

Serum, CRMs

Liver

Serum, CSF

MS; ICP; SEC; MS; ICP; LA

AA; ETA; L

XRF; -; -

$\begin{array}{lll}\text { Mo } & \text { Serum } & \text { MS; ICP; L } \\ \text { Mo } & \text { Urine RMs } & \text { AA; ETA; S }\end{array}$

See Br, ref. 35

See Ga, ref. 111

A candidate reference method was proposed as a less expensive alternative to the NIST reference method (which is based on cold plasma ID-ICP-MS with ${ }^{41} \mathrm{~K}$ ). Instead, ${ }^{59} \mathrm{Co}$ was used as an internal standard and interferences were reduced by applying the DRC technology with $\mathrm{NH}_{3}$ as the reaction gas. $\mathrm{K}$ concentrations in samples diluted $1+99$ with $1 \% \mathrm{HNO}_{3}$ were calculated using the bracketing technique. Linearity was reported between 0.0000 and $6.87 \mathrm{mmol} \mathrm{L}^{-1}\left(r^{2}=1.000\right)$. Intermediate precision, assessed on 2 patient samples, gave RSDs $(n=18)$ of $0.09 \%$ at $4.300 \mathrm{mmol} \mathrm{L}^{-1}$ and $0.14 \%$ at $4.678 \mathrm{mmol} \mathrm{L}^{-1}$. Recovery of spiked amounts to 3 patient samples ranged from $99.67 \%$ to $99.88 \%$. Analysis of 3 NIST SRMs gave mean measured values $(n=12)$ within the stated ranges. The expanded uncertainty (95\%) of the results was estimated as $0.76 \%$

As part of a study of the effect of Zn dietary intake on the levels and distributions of 26 elements in blood and tissues of growing rats, changes in Mn distribution in liver were reported in detail The mechanisms of $\mathrm{Mn}$ transport across the neural barrier were investigated by determining Mn species in paired serum and CSF samples by means of SEC and CE coupled to DRC-ICP-MS

See Cr, ref. 34

An investigation of calibration strategies for portable XRF instruments was carried out, using $\mathrm{Mn}$ and $\mathrm{Zn}$ determinations as a model. Using samples at different concentration and with different mass, an empirical relationship between slope and mass was established

See Cr, ref. 43

The potential of dried urine spots for the monitoring of Mo and $\mathrm{Ti}$ levels in urine of patients with metallic prostheses was investigated. After careful sample collection, solid samples were presented to HR-CS-ETAAS and Mo and Ti concentrations obtained using a matrix-matched calibration strategy. The LODs were $1.5 \mu \mathrm{g} \mathrm{L}^{-1}$ (Mo) and $6.5 \mu \mathrm{g} \mathrm{L} \mathrm{L}^{-1}$ (Ti). The method was tested on urine RMs
Ref. 
Table 2 (Contd.)

\begin{tabular}{|c|c|c|c|c|}
\hline Element & Matrix & $\begin{array}{l}\text { Technique;atomisation; } \\
\text { presentation }\end{array}$ & Sample treatment/comments & Ref. \\
\hline $\mathrm{Na}$ & Sweat & MS; ICP; L & See Cl, ref. 112 & 112 \\
\hline $\mathrm{Nb}$ & Serum & MS; ICP; L & See Al, ref. 44 & 44 \\
\hline $\mathrm{Ni}$ & Serum & MS; ICP; L & See Cr, ref. 43 & 43 \\
\hline $\mathrm{Ni}$ & $\begin{array}{l}\text { Blood, plasma and } \\
\text { urine }\end{array}$ & MS; ICP; L & See Co, ref. 40 & 40 \\
\hline $\mathrm{Ni}$ & Urine & $\mathrm{AA} ;-;-$ & $\begin{array}{l}\text { In a sample of } 164 \text { female patients with and without Ni contact } \\
\text { dermatitis, higher Ni urinary excretion was associated with age } \\
\text { and consumption of dietary supplements but not with the } \\
\text { occurrence of Ni contact sensitisation }\end{array}$ & 119 \\
\hline $\mathrm{Ni}$ & Urine & AA; ETA; L & $\begin{array}{l}\text { Ni levels were determined in urine samples from } 1576 \text { children, } \\
\text { aged } 3-14 \text { years, as part of the German Environmental Survey and } \\
\text { ranged from }<0.5 \text { to } 15 \mu \mathrm{g} \mathrm{L}^{-1} \text {, with a geometric mean of } 1.26 \mu \mathrm{g} \\
\mathrm{L}^{-1} \text {. Urinary creatinine concentration was the most important } \\
\text { predictor of Ni levels }\end{array}$ & 118 \\
\hline Os & $\begin{array}{l}\text { Pharmaceutical } \\
\text { ingredients and } \\
\text { products }\end{array}$ & MS; ICP; L & $\begin{array}{l}\text { An investigation, driven by new regulatory requirements, } \\
\text { concluded that volatile Os species, formed after pressure vessel } \\
\text { digestion of pharmaceutical ingredients with } \mathrm{HNO}_{3} \text {, could be } \\
\text { stabilised by post digestion addition of thiourea and ascorbic } \\
\text { acid. The average recovery of spiked amounts of } 1.0 \mu \mathrm{g} \mathrm{g}^{-1} \text { Os was } \\
81 \% \text { and RSD\% was } 7 \%(n=6)\end{array}$ & 33 \\
\hline $\mathrm{P}$ & $\begin{array}{l}\text { Liposomal } \\
\text { formulations }\end{array}$ & MS; ICP; CE & $\begin{array}{l}\text { The simultaneous quantification of phospholipids }(\mathrm{P}) \text { and } \\
\text { cisplatin }(\mathrm{Pt}) \text { after CE allowed the monitoring of the fate of } \\
\text { cisplatin in experimental studies investigating Pt release and } \\
\text { liposome stability in human plasma of liposomal formulations of } \\
\text { anticancer drugs }\end{array}$ & 158 \\
\hline $\mathrm{Pb}$ & Medicinal plants & AA; ETA; S & $\begin{array}{l}\text { A procedure was developed to determine } \mathrm{Pb} \text { in medicinal plants } \\
\text { by HR-CS-ETAAS using direct solid sampling with } \mathrm{Pd}\left(\mathrm{NO}_{3}\right)_{2} \text { as a } \\
\text { chemical modifier. Linearity between } 10 \text { and } 1000 \mathrm{pg} \mathrm{Pb} \text { was } \\
\text { achieved. The LOQ was } 0.024 \mu \mathrm{g} \mathrm{g}^{-1} \text { per day } \mathrm{w} \text {. and the RSD at } \\
0.88 \mu \mathrm{g} \mathrm{g}^{-1} \text { was } 10 \%(n=3) \text {. The analysis of } 5 \text { plant CRMs and } \\
\text { comparison with an alternative technique gave satisfactory } \\
\text { results. In medicinal plant samples, Pb levels ranging from } 0.30 \\
\text { and } 1.94 \mu \mathrm{g} \mathrm{g}^{-1} \text { were determined }\end{array}$ & 64 \\
\hline $\mathrm{Pb}$ & $\begin{array}{l}\text { Blood, urine, and } \\
\text { faeces }\end{array}$ & $\mathrm{MS} ; \mathrm{ICP} ; \mathrm{L}$ & $\begin{array}{l}\text { The fractionation of } \mathrm{Pb} \text { isotopes during biological processes was } \\
\text { investigated in } 24 \text { Sprague-Dawley rats exposed to }\left(\mathrm{CH}_{3} \mathrm{COO}\right)_{2} \mathrm{~Pb} \\
\text { via the respiratory tract. The } \mathrm{Pb} \text { isotopic composition in blood, } \\
\text { urine and faeces samples was compared with those of the } \\
\text { administered } \mathrm{Pb} \text { salt and of the rat diet }\end{array}$ & 116 \\
\hline $\mathrm{Pb}$ & Bones & $\begin{array}{l}\text { XRF; -; -; MS; } \\
\text { ICP; LA }\end{array}$ & $\begin{array}{l}\text { The distribution of } \mathrm{Pb} \text { isotopes in bone fragments from the } \\
\text { remains associated with the Franklin expedition was determined } \\
\text { by micro SR XRF spectrometry and compared with the results of } \\
\text { LA-ICP-MS }\end{array}$ & 78 \\
\hline $\mathrm{Pt}$ & Blood plasma & MS; ICP; L & $\begin{array}{l}\text { Using a novel microfluidic chip-based nanoflow injection system, } \\
40 \text { to } 200 \mathrm{~nL} \text { could be introduced directly into an ICP-mass } \\
\text { spectrometer. The absolute LOD of } 2.54 \text { fg achieved for }{ }^{195} \mathrm{Pt} \text { was } \\
\text { considerably lower than typical LODs with a conventional } \\
\text { nebuliser. The sample throughput was } 48 \mathrm{~h}^{-1} \text {. The RSDs }(n=10) \text {, } \\
\text { based on peak heights, at a level of } 10 \mu \mathrm{g} \mathrm{L} \mathrm{L}^{-1} \text { were } 1.5 \% \text { for } \\
\text { aqueous solutions and } 2.7 \% \text { for plasma samples. The results } \\
\text { obtained on plasma samples were compared with those obtained } \\
\text { by conventional ICP-MS, with recoveries ranging between } 94.3 \% \\
\text { and } 103.0 \%(n=6)\end{array}$ & 49 \\
\hline $\mathrm{Pt}$ & $\begin{array}{l}\text { Liposomal } \\
\text { formulations }\end{array}$ & MS; ICP; CE & See P, ref. 158 & 158 \\
\hline $\mathrm{Pt}$ & Urine & MS; ICP; L & $\begin{array}{l}\text { The unexpected presence of Gd, from a contrast agent for MRI, in } \\
\text { urine specimens collected for an investigation focusing on } \\
\text { environmental exposures and endometriosis (ENDO Study), was } \\
\text { identified, using SF-ICP-MS, as the cause of interferences } \\
\text { affecting the results of Pt and Se determinations by ICP-QMS }\end{array}$ & 37 \\
\hline $\mathrm{Pt}$ & Cells & $\begin{array}{l}\text { MS; ICP; LC; } \\
\text { MS; ICP; FI }\end{array}$ & $\begin{array}{l}\text { A procedure was developed to quantify intact cisplatin in a cell } \\
\text { model and applied to study the pharmacokinetics of this drug at a } \\
\text { cellular level }\end{array}$ & 120 \\
\hline
\end{tabular}


Table 2 (Contd.)

\begin{tabular}{|c|c|c|c|c|}
\hline Element & Matrix & $\begin{array}{l}\text { Technique;atomisation; } \\
\text { presentation }\end{array}$ & Sample treatment/comments & Ref. \\
\hline $\mathrm{Sb}$ & $\begin{array}{l}\text { Human milk, saliva } \\
\text { and urine }\end{array}$ & $-;-;-$ & $\begin{array}{l}\text { A critical review of reported Sb concentrations in human milk, } \\
\text { saliva and urine was presented }\end{array}$ & 14 \\
\hline $\mathrm{Sb}$ & Urine, CRMs & AA; ETA; L & $\begin{array}{l}\text { Sb was chelated by thenoyltrifluoroacetone and the chelates } \\
\text { extracted in supercritical } \mathrm{CO}_{2} \text { at } 60^{\circ} \mathrm{C} \text { and } 17.2 \mathrm{MPa} \text {. Analysis of } \\
\text { the extracts was carried out by ETAAS, using } \mathrm{Pd}\left(\mathrm{NO}_{3}\right)_{2}-\mathrm{Mg}\left(\mathrm{NO}_{3}\right)_{2} \\
\text { as the chemical modifier. The RSD was }<5 \% \text { and the recovery } \\
\text { from } 6 \text { spiked samples ranged from } 95.6 \% \text { and } 102.9 \%\end{array}$ & 108 \\
\hline Sc & Urine & AE; ICP; L & See Eu, ref. 121 & 121 \\
\hline Se & $\begin{array}{l}\text { Tissues (heart, brain } \\
\text { and liver) }\end{array}$ & AA; ETA; L & $\begin{array}{l}\text { In patients treated with neuroleptic drugs, a significant reduction } \\
\text { of Se levels was observed in heart tissue, but not in liver or brain } \\
\text { tissue, from samples collected at autopsy. }\end{array}$ & 159 \\
\hline Se & Red blood cells & MS; ICP; SEC & $\begin{array}{l}\text { The concentration of the Se-enzyme GPx was quantitatively } \\
\text { determined in red blood cells as a marker of oxidative status and } \\
\text { compared with spectrophotometric measurements of the enzyme } \\
\text { activity. The procedure involved Hb precipitation followed by } \\
\text { SEC-ICP-MS using post-column IDA }\end{array}$ & 122 \\
\hline $\mathrm{Se}$ & $\begin{array}{l}\text { Blood serum and } \\
\text { CSF }\end{array}$ & $\begin{array}{l}\text { MS; ICP; HPLC; } \\
\text { MS; ICP; SEC }\end{array}$ & $\begin{array}{l}\text { To investigate the crossing of the neural barrier by Se-species, Se } \\
\text { species (selenoprotein P, SeMet, GPx, thioredoxin reductase, } \\
\text { selenoalbumin, SeCys, } \mathrm{Se}^{\mathrm{IV}}, \mathrm{Se} \mathrm{VI}^{\mathrm{VI}} \text {, others) were determined in } \\
\text { serum and CSF paired samples, from } 24 \text { neurologically healthy } \\
\text { subjects, using different combinations of separation techniques } \\
\text { (strong anion exchange chromatography, 2D SEC, CE) coupled to } \\
\text { ICP-DRC-MS. From the experimental data, the LOD (as } 3 \mathrm{SD} \text { of } \\
\text { noise) for all investigated species was set to } 0.032 \mu \mathrm{g} \mathrm{L} \mathrm{L}^{-1}\end{array}$ & 86 \\
\hline Se & Biological CRMs & MS; ICP; L & $\begin{array}{l}\text { Elimination or reduction of interferences in the direct } \\
\text { determination of Se at } \mathrm{ng}^{-1} \text { levels in biological samples was } \\
\text { achieved using a } \mathrm{CH}_{4}-\mathrm{Ar} \text { mixed plasma and DRC technology. The } \\
\text { signal enhancement due to the presence of } \mathrm{C} \text { in the plasma } \\
\text { improved the sensitivity by a factor of } 3 \text {. In addition, with an } \\
\text { elaborate evaporation procedure, Br was removed from the digested } \\
\text { samples to eliminate the remaining overlapping interference of } \\
{ }^{79} \mathrm{BrH}^{+} \text {on }{ }^{80} \mathrm{Se}^{+} \text {. The method was tested on } 50 \text { biological CRMs }\end{array}$ & 36 \\
\hline $\mathrm{Se}$ & Urine & MS; ICP; L & See Pt, ref. 37 & 37 \\
\hline Se & Cells & $\begin{array}{l}\text { XAS; -; -; MS; ICP; } \\
\text { HPLC; MS/MS; ESI; L }\end{array}$ & $\begin{array}{l}\text { A review of approaches, based on different analytical techniques, } \\
\text { for the speciation of Se in cells and tissues was presented }\end{array}$ & 9 \\
\hline $\mathrm{Sr}$ & Bone & $\mathrm{XRF} ;-;-$ & $\begin{array}{l}\text { Accumulation of } \mathrm{Sr} \text { ranelate, a drug used for osteoporosis } \\
\text { treatment, and } \mathrm{Sr} \text { citrate, a nutritional supplement, in bones was } \\
\text { investigated in rats by in vivo XRF spectrometry }\end{array}$ & 77 \\
\hline $\mathrm{Ti}$ & Blood & MS; ICP; L & See Co, ref. 41 & 41 \\
\hline $\mathrm{Ti}$ & Urine & AA; ETA; & See Mo, ref. 19 & 19 \\
\hline $\mathrm{Ti}$ & Serum & MS; ICP; L & See $\mathrm{Al}$, ref. 44 & 44 \\
\hline $\mathrm{Ti}$ & Serum & MS; ICP; L & $\begin{array}{l}\text { The release of Ti in serum following cementless total hip } \\
\text { arthroplasty using a novel modular stem system, assessed in a } \\
\text { retrospective cross-sectional study, did not differ from that } \\
\text { observed from a non modular device and the observed levels were } \\
\text { low for both implants }\end{array}$ & 46 \\
\hline $\mathrm{U}$ & Bones, water & MS; ICP; L & $\begin{array}{l}\text { An attempt to derive a mathematical model to predict U content } \\
\text { in the skeleton following low level environmental exposure was } \\
\text { reported. The model was based on U concentrations measured, } \\
\text { after acid digestion, in } 71 \text { archived vertebrae bone samples from } 7 \\
\text { Canadian cities and historical data on the U concentrations in the } \\
\text { corresponding municipal drinking water supplies }\end{array}$ & 126 \\
\hline $\mathrm{Y}$ & Urine & AE; ICP; L & See Eu, ref. 121 & 121 \\
\hline $\mathrm{Zn}$ & Rat brain & MS; ICP; LA & $\begin{array}{l}\text { A feasibility study to investigate the application of stable } \mathrm{Zn} \\
\text { isotopes as tracers for the imaging of } \mathrm{Zn} \text { pathways in brain was } \\
\text { carried out in dosed rats, determining the }{ }^{67} \mathrm{Zn}:{ }^{70} \mathrm{Zn} \text { ratio by LA- } \\
\text { MC-ICP-MS }\end{array}$ & 127 \\
\hline $\mathrm{Zn}$ & Serum & MS; ICP; L & $\begin{array}{l}\text { In a sample of } 220 \text { low birth weight and } 119 \text { normal birth weight } \\
\text { infants in India, } \mathrm{Zn} \text { status was estimated at birth from the } \mathrm{Zn} \\
\text { concentrations in paired mother-newborn serum samples and, } \\
\text { subsequently, on the infant serum samples collected between } 2 \\
\text { and } 10 \text { months of age. Poor Zn status was common and not } \\
\text { associated with low birth weight }\end{array}$ & 160 \\
\hline
\end{tabular}


Table 2 (Contd.)

\begin{tabular}{|c|c|c|c|c|}
\hline Element & Matrix & $\begin{array}{l}\text { Technique;atomisation; } \\
\text { presentation }\end{array}$ & Sample treatment/comments & Ref. \\
\hline $\mathrm{Zn}$ & Nails & XRF; - ; - & See Mn, ref. 157 & 157 \\
\hline Various & Tissues & MS; ICP; LA & $\begin{array}{l}\text { The use of } \mathrm{H}_{2} \text { as the collision gas at a flow of } 3 \mathrm{~mL} \mathrm{~min}{ }^{-1} \text { reduced } \\
\text { O- and } \mathrm{N} \text {-based interferences, thus improving analytical } \\
\text { sensitivity for the elemental bioimaging of } \mathrm{Ca}, \mathrm{Co}, \mathrm{Cu}, \mathrm{Fe}, \mathrm{Mn} \text { and } \\
\mathrm{Zn}\end{array}$ & 94 \\
\hline Various & $\begin{array}{l}\text { Soft and skeletal } \\
\text { tissues }\end{array}$ & $\mathrm{XRF} ;-;-$ & $\begin{array}{l}\text { The criticality of sample thickness for quantitative analysis of } \\
\text { human tissues was discussed with regard to specific } \\
\text { requirements for individual elements }\end{array}$ & 79 \\
\hline Various & $\begin{array}{l}\text { Single cells, cellular } \\
\text { structures }\end{array}$ & SIMS; - ; - & $\begin{array}{l}\text { A review was presented of advances in mass spectrometry (SIMS } \\
\text { and MALDI-MS) for imaging and profiling of individual cells and } \\
\text { subcellular structures }\end{array}$ & 10 \\
\hline Various & $\begin{array}{l}\text { Environmental, } \\
\text { biological and food } \\
\text { samples }\end{array}$ & $\begin{array}{l}\text { AA; -; -; AE; ICP; } \\
\text { L; MS; ICP; L }\end{array}$ & $\begin{array}{l}\text { A review of the application of carbon nanotubes as solid-phase } \\
\text { extraction sorbents was presented }\end{array}$ & 8 \\
\hline Various & Hair & SIMS; -; - & $\begin{array}{l}\text { An assessment of the influence of washing procedures on the } \\
\text { removal of } \mathrm{Ca}, \mathrm{Fe}, \mathrm{K}, \mathrm{Mg} \text { and } \mathrm{Na} \text { from the surface and/or the } \\
\text { inside of hair was reported }\end{array}$ & 107 \\
\hline Various & Brain & MS; ICP; SEC & $\begin{array}{l}\text { The presence of labile low } M_{\mathrm{r}} \text { complexes of } \mathrm{Co}, \mathrm{Cu}, \mathrm{Fe}, \mathrm{Mn}, \mathrm{Mo} \\
\text { and } \mathrm{Zn} \text { in brain cellular structures was investigated. Supernatant } \\
\text { fractions of fresh mouse brain homogenates were filtered on a } \\
10 \mathrm{kDa} \text { cut-off membrane and separated by SEC under anaerobic } \\
\text { refrigerated conditions for measuring the concentration of these } \\
\text { metals and those of } \mathrm{P} \text { and } \mathrm{S} \text { by ICP-MS. }\end{array}$ & 161 \\
\hline Various & $\begin{array}{l}\text { Blood serum and } \\
\text { CSF }\end{array}$ & MS; ICP; L & $\begin{array}{l}\text { The concentrations of several elements, including } \mathrm{Al}, \mathrm{Cd}, \mathrm{Co}, \mathrm{Cu} \text {, } \\
\mathrm{Mn}, \mathrm{Pb}, \mathrm{V}, \mathrm{U} \text { and } \mathrm{Zn} \text {, were measured by means of HR-ICP-MS in } \\
\text { paired serum and CSF samples from } 17 \text { patients suffering from } \\
\text { amyotrophic lateral sclerosis as diagnosed by quantitative } \\
\text { electromyography }\end{array}$ & 104 \\
\hline Various & - & $-;-;-$ & $\begin{array}{l}\text { This review covered novel developments in instrumentation, } \\
\text { techniques and methodology in AES, AAS, AFS and atomic MS, } \\
\text { including photochemical and electrochemical methods of VG, } \\
\text { single particle ICP-MS and direct plasma generation in liquid } \\
\text { samples }\end{array}$ & 5 \\
\hline Various & $\begin{array}{l}\text { Environmental, } \\
\text { food and biological } \\
\text { samples }\end{array}$ & $-;-;-$ & $\begin{array}{l}\text { A review of recent developments in dispersive liquid liquid } \\
\text { microextraction as a sample pre-treatment technique was } \\
\text { presented, highlighting the exploration of new extraction and } \\
\text { dispersion solvents and the combination with other techniques }\end{array}$ & 11 \\
\hline Various (REE) & Bones & MS; ICP; LA & $\begin{array}{l}\text { The REE distribution patterns were determined across } 54 \text { fossil } \\
\text { bones aged from the Triassic to the early Medieval period }\end{array}$ & 97 \\
\hline Various (4) & $\begin{array}{l}\text { Erythrocytes, serum } \\
\text { and urine }\end{array}$ & MS; ICP; L & $\begin{array}{l}\text { The concentrations of Cr, Co, Mo and Ni were measured in } \\
\text { erythrocytes of } 25 \text { patients with a hip resurfacing implant by } \\
\text { means of SF-ICP-MS and compared to the levels in paired serum, } \\
\text { erythrocyte and urine samples from } 27 \text { controls without an } \\
\text { implant. Patients had lower erythrocyte levels of Co }(0.10 v s .3 .26 \\
\left.\mu g \mathrm{~kg}^{-1}\right) \text { and Cr }\left(6.04 v s .7 .38 \mu \mathrm{kg}^{-1}\right) \text {, but higher levels for all } \\
\text { measured elements in serum }\end{array}$ & 42 \\
\hline Various (4) & Brain & MS; ICP; L; AA; F; L & $\begin{array}{l}\text { The concentrations of } \mathrm{Cu}, \mathrm{Fe}, \mathrm{Mn} \text { and } \mathrm{Zn} \text { were measured in } \\
\text { samples from different regions of brain, taken at autopsy from } 12 \\
\text { Wilson's Disease (WD) patients and } 5 \text { controls. Beside } \\
\text { unsurprisingly high Cu levels in WD patients }\left(41.0 \pm 18.6 \mu \mathrm{g} \mathrm{g}^{-1}\right. \\
\left.\text { vs. } 5.4 \pm 1.8 \mu \mathrm{g} \mathrm{g}^{-1} ; p<0.01\right) \text {, increased levels of Fe were also } \\
\text { observed but only in the nucleus dentatus region }(56.8 \pm 14.1 \mu \mathrm{g} \\
\left.\mathrm{g}^{-1} \text { vs. } 32.6 \pm 6.0 \mu \mathrm{g} \mathrm{g}^{-1} ; p<0.05\right)\end{array}$ & 106 \\
\hline Various (4) & Tissues & MS; ICP; LA & $\begin{array}{l}\text { The presence of } \mathrm{Al} \text { and } \mathrm{Br} \text { in the chemical structures of the } \\
\text { histological stains haematoxylin and eosin was exploited to } \\
\text { improve the power of this imaging technique in stained tissues } \\
\text { (appendix, lymph nodes, Fallopian tube and oesophageal tumour } \\
\text { tissues). A collision/reaction cell was applied to reduce } \\
\text { interferences on } \mathrm{Al} \text { or Br. In addition, } \mathrm{C} \text { and Pt distributions were } \\
\text { also investigated in unstained and stained human oesophageal } \\
\text { tumour sections after cisplatin therapy }\end{array}$ & 95 \\
\hline
\end{tabular}
tumour sections after cisplatin therapy 
Table 2 (Contd.)

\begin{tabular}{|c|c|c|c|c|}
\hline Element & Matrix & $\begin{array}{l}\text { Technique;atomisation; } \\
\text { presentation }\end{array}$ & Sample treatment/comments & Ref. \\
\hline Various (8) & Metal accessories & MS; ICP; L & $\begin{array}{l}\text { From a concern about infants swallowing objects by mistake, the } \\
\text { release of potentially toxic metals (As, } \mathrm{Ba}, \mathrm{Cd}, \mathrm{Cr}, \mathrm{Hg}, \mathrm{Pb}, \mathrm{Sb} \text { and } \\
\mathrm{Se} \text { ) from small metal accessories contained in products other } \\
\text { than infant toys was addressed in a survey of } 117 \text { products. } \mathrm{Pb} \\
\text { release was above permitted limits in } 28 \text { cases and } \mathrm{Cd} \text { in one case }\end{array}$ & 162 \\
\hline Various (12) & Herbal supplements & $\begin{array}{l}\text { MS; ICP; L; MS; } \\
\text { ICP; LA }\end{array}$ & $\begin{array}{l}\text { A method based on LA-ICP-MS to determine the concentrations of } \\
\mathrm{Al}, \mathrm{Ca}, \mathrm{Cd}, \mathrm{Cr}, \mathrm{Co}, \mathrm{Cu}, \mathrm{Fe}, \mathrm{Mg}, \mathrm{Mn}, \mathrm{Ni}, \mathrm{V} \text { and } \mathrm{Zn} \text { in six herbal } \\
\text { supplements, Korean Panax Ginseng (Panax ginseng), Golden Seal } \\
\text { (Hydrastis canadensis), Ginger Root (Zingiber officinale), St. John's } \\
\text { Wort (Hypericum perforatum), Green Tea (Camellia sinensis) and } \\
\text { Valerian Root (Valeriana officinalis), was compared with } \\
\text { conventional ICP-MS }\end{array}$ & 129 \\
\hline Various & Urine & MS; ICP; L & $\begin{array}{l}\text { Reference ranges for } 31 \text { elements in } 24 \text { h urine collections were } \\
\text { reported, based on the analysis of specimens collected from } 111 \\
\text { healthy subjects }\end{array}$ & 18 \\
\hline Various (26) & Urine & MS; ICP; L & $\begin{array}{l}\text { Reference values and upper reference limits for } 26 \text { chemical } \\
\text { elements (Al, } \mathrm{As}, \mathrm{Ba}, \mathrm{Be}, \mathrm{Bi}, \mathrm{Cd}, \mathrm{Cr}, \mathrm{Co}, \mathrm{Cu}, \mathrm{Hg}, \mathrm{In}, \mathrm{Li}, \mathrm{Mn}, \mathrm{Mo}, \mathrm{Ni} \text {, } \\
\mathrm{Pd}, \mathrm{Pt}, \mathrm{Pb}, \mathrm{Se}, \mathrm{Te}, \mathrm{Tl}, \mathrm{Sb}, \mathrm{Sn}, \mathrm{U}, \mathrm{V}, \mathrm{Zn}) \text { in urine were established for } \\
\text { the Belgian general adult population, by analysing fasting spot } \\
\text { urine samples from a total of } 1022 \text { subjects ( } 460 \text { males and } 541 \\
\text { females) }\end{array}$ & 17 \\
\hline Various (69) & Animal teeth & MS; ICP; LA & $\begin{array}{l}\text { The concentrations of } 69 \text { minor and trace elements in multiple } \\
\text { teeth of } 145 \text { animals, including modern herbivores (Cervus } \\
\text { elaphus, Odocoileus hemionus, Odocoileus virginianus), omnivores } \\
\text { (Ursus americanus) and carnivores (Felis concolor; Canis lupus) } \\
\text { from Idaho, USA. were determined }\end{array}$ & 98 \\
\hline
\end{tabular}

Possible interferences were shown for $\mathrm{Cr}$ and $\mathrm{Cu}$ in aqueous solutions but analysis of the CRM DORM-2, dogfish muscle gave an acceptable result. The method was applied to the analysis of Brazil nuts, apricot, white bean, rice flour, and milk powder. Samples were prepared for analysis by acid digestion and reduction of $\mathrm{Se}^{\mathrm{IV}}$ to $\mathrm{Se}^{0}$ by ascorbic acid.

Three different approaches to sample preparation for measurement of $\mathrm{Hg}$ were reported. Oreste et $\mathrm{al}^{\mathbf{2 4}}$ designed apparatus for digestion that incorporated a water-filled glass finger within the reaction vessel to prevent loss of analyte and digestion acid. The device required a small amount of acid and effected $\mathrm{HNO}_{3}$ digestion in 2 hours at 90-120 ${ }^{\circ} \mathrm{C}$. An alkaline extraction, facilitated by closed vessel microwave heating, was used by Nevado et $a .^{25}$ in a method to measure concentrations of $\mathrm{MeHg}$ and $\mathrm{Hg}^{2+}$ in liver and kidney from wild deer and boar living in a mercury mining area of Spain. Hayashi et al., ${ }^{26}$ however, found that 2-mercaptoethanol also effectively extracted $\mathrm{Hg}$ for speciation. Both groups used AFS for the eventual determination of $\mathrm{Hg}$.

An unusual complexing agent, Acridine Orange in Triton $\mathrm{X}-114$, was introduced by Ulusoy et al. ${ }^{27}$ for cloud point extraction and pre-concentration of $\mathrm{Pb}$ and $\mathrm{Sn}$ from canned food samples. Liao et al. ${ }^{28}$ employed a cloud point extraction procedure to preconcentrate $\mathrm{Cd}, \mathrm{Hg}$ and $\mathrm{Sb}$ from a variety of water samples prior to determination by ID-VG-ICP-MS. The extraction was facilitated by microwave heating at $\mathrm{pH}$ 5.0. Optimization of the VG was the focus of this work. Thiourea $(0.9 \% \mathrm{~m} / \mathrm{v})$ and $\mathrm{Cd}(0.1 \mu \mathrm{g}$ $\mathrm{L}^{-1}$ ) catalysed the vaporisation and the best response was seen with $0.8 \% \mathrm{~m} / \mathrm{v} \mathrm{NaBH}_{4}$ in $0.2 \% \mathrm{~m} / \mathrm{v} \mathrm{NaOH}$ as the reductant.
We have previously reported the use of pressurised hot water to extract analytes without perturbing their speciation. ${ }^{29}$ One of the proponents of this technique, Moreda-Pineiro ${ }^{30}$ has now applied the procedure to the analysis of human scalp hair and determined the concentrations of As species. As the methodology for real samples is far from straightforward, requiring drying and powdering, it is not surprising that pressurised hot water extraction has not proven to be widely used.

Reviews of dispersive microextraction and of SPE with carbon nanotubes ${ }^{\mathbf{8}, 11}$ were noted above. Reflecting this interest were the number of publications during the year that mentioned these preparative procedures in their methodologies, ${ }^{31,32}$ for example.

Preparation of pharmaceuticals for the determination of trace elements were reported in three publications. Venzago et al. ${ }^{33}$ noted that the new US Pharmacopeia General Chapters required the testing for Os in pharmaceutical products and described a method that avoided loss of volatile species that form during pressure vessel acid digestion. It was found that thiourea and ascorbic acid will stabilise Os and, in experiments using Avicel, $81 \%$ of $1.0 \mu \mathrm{g} \mathrm{g}^{-1}$ Os was recovered. Focused ultrasoundassisted extraction ${ }^{34}$ was used in a procedure to measure concentrations of $\mathrm{Cr}$ and $\mathrm{Mn}$ in ciprofloxacin, cephalexin, azithromycin, amiodipine and methionine. Experiments to optimise the extraction conditions led to a method that used 25-150 mg of sample in $5 \mathrm{~mL} 1 \mathrm{~mol} \mathrm{~L}^{-1} \mathrm{HCl}$, sonicated at $50 \%$ power for $30 \mathrm{~min}$. Concentrations of $\mathrm{Cr}$ and $\mathrm{Mn}$ were determined by ETAAS and the results obtained were not statistically different from those obtained after preparation by acid digestion. This work was similarly initiated by the announcement 
from the US Pharmacopeia although the implementation date was subsequently postponed. Concentrations of $\mathrm{Br}$ and I in ten pharmaceuticals were measured following microwave-induced combustion. ${ }^{35}$ Samples, $500 \mathrm{mg}$, were combusted within $30 \mathrm{~s}$ at an $\mathrm{O}_{2}$ pressure of $30 \mathrm{bar}$, and the residue taken into $50 \mathrm{mmol}$ $\mathrm{L}^{-1}\left(\mathrm{NH}_{4}\right)_{2} \mathrm{CO}_{3}$, promoted by a $5 \mathrm{~min}$ reflux step. The $\mathrm{C}$ content of the digests was low and analysis of CRMs agreed with the certified values. The LODs for Br and I, measured by ICP-MS, were 0.02 and $0.001 \mu \mathrm{g} \mathrm{g}^{-1}$, respectively.

\section{Progress with analytical techniques}

\subsection{Mass spectrometry}

4.1.1 Inductively coupled plasma-mass spectrometry. The use of carbon to enhance the sensitivity of selenium in ICP-MS has been well known for a number of years. However, Guo and coworkers ${ }^{36}$ combined the addition of $\mathrm{CH}_{4}$ to the sample gas through the spray chamber with $\mathrm{CH}_{4}$ as the reaction cell gas. The interferences typically expected on ${ }^{80}$ Se were significantly reduced to allow accurate quantification. Steuerwald et al. ${ }^{37}$ reported the unusual findings of extremely elevated levels of $\mathrm{Pt}$ and Se in urine of participants in a study investigating environmental exposure and endometriosis. On further research, it became clear that severe Gd-based interferences were present caused by the use of Gd-based contrast agents for MRI. The work highlighted the importance of careful interpretation of extreme results. An interesting but somewhat outdated theory was reported by Donati et $a .^{38}$ for minimising the effect of interferences in ICP-QMS. The principle was to use plasmabased species as internal standards and was demonstrated with ${ }^{28} \mathrm{Si}^{+}$using ${ }^{36} \mathrm{ArH}^{+}$and ${ }^{38} \mathrm{Ar}^{+}$for 'correction'. Improvements in accuracy were shown but of limited practical use considering the proliferation of collision-reaction cell based technology.

Over the past year, the topic of metal replacement joints has received significant attention. During 2012, the UK's Medicines and Healthcare products Regulatory Agency (MHRA) issued three 'medical device alert' (MDA/2012/016, MDA/2012/035 and MDA/2012/036) regarding patients with 'metal-on-metal' hip joints and provided guidance levels for metal ions in whole blood ( 7 ppb for both Co and $\mathrm{Cr}$ ). A number of publications reported methods and data for $\mathrm{Co}, \mathrm{Cr}, \mathrm{Mo}, \mathrm{Ni}$ and $\mathrm{Ti}$ from clinical studies of various replacement joints in different biological samples; whole blood, ${ }^{39-41}$ erythrocytes, ${ }^{42}$ serum, ${ }^{42-46}$ plasma $^{40}$ and urine. ${ }^{40,42}$ Cieslak et al. ${ }^{47}$ determined $\mathrm{Cr}$ in whole blood by CC-ICP-MS to establish reference ranges for healthy individuals in Ohio, USA. The results provided much needed data on background $\mathrm{Cr}$ levels in whole blood, reporting the reference interval as 3.92 to $7.48 \mathrm{nmol} \mathrm{L}^{-1}$.

The production of a microfluidic chip for FI into an ICP-mass spectrometer for the direct analysis of alcoholic spirits without sample preparation was described by Hao et al. ${ }^{48}$ Sub-microlitre samples could be used with good repeatability and low detection limits achieved for the determination of $\mathrm{Cd}$ and $\mathrm{Pb}$ (42 and $12 \mathrm{ng} \mathrm{\textrm {L } ^ { - 1 }}$, respectively), in addition to high sample throughput $\left(45 \mathrm{~h}^{-1}\right)$. However, the use of small volume analysis for beverages would seem to be unnecessary. The technology was developed further by $\mathrm{Wu}$ and co-workers ${ }^{49}$ from the same group that produced the previous article by reducing the sample volumes to $\mathrm{nL}$ levels and applied it to the determination of $\mathrm{Pt}$ in human plasma samples. The LOD achieved was $2.54 \mathrm{fg}$ for ${ }^{195} \mathrm{Pt}$ for a $200 \mathrm{~nL}$ injection and precision was less than $3 \% \mathrm{RSD}$. With low sample consumption and high throughput $\left(48 \mathrm{~h}^{-1}\right)$ reported, the technique showed significant promise.

The accurate measurement of ultra-trace toxic elements such as $\mathrm{Cd}, \mathrm{Sb}$ and $\mathrm{Hg}$ is becoming more important as legislative limits are decreased. Liao et $a .^{28}$ combined CPE to pre-concentrate natural water samples utilising IDA with FI-VG-ICP-MS. It enabled LODs several orders of magnitude below conventional pneumatic nebulisation (2, 0.6 and $5 \mathrm{ng} \mathrm{L}^{-1}$ for $\mathrm{Cd}, \mathrm{Hg}$, and $\mathrm{Sb}$, respectively) under optimised conditions.

The continued interest in nanoparticle behaviour has shown specific attention to $\mathrm{Ag}$ this year. Espinosa-Cristobal et al. ${ }^{\mathbf{5 0}}$ reported clinical data regarding the toxicity, distribution and accumulation of Ag nanoparticles of two different sizes (14 and $36 \mathrm{~nm}$ ) exposed to rats. The analysis of the tissue samples by ICP-MS indicated the highest accumulation of $\mathrm{Ag}$ in the small intestine, followed by kidney, liver and brain. Results of haematological and histopathological tests were also provided. Overall, the group concluded that the Ag nanoparticles studied, within the bounds of the experiment, did not cause any significant effect. Hadioui and co-workers ${ }^{51}$ applied multiple methods to investigate the postulated effect of free $\mathrm{Ag}^{+}$release from $\mathrm{Ag}$ nanoparticles. An ion-exchange technique combined with ultrafiltration and single particle ICP-MS provided data to suggest dilution played a key role in the chemistry of $\mathrm{Ag}$ nanoparticles.

The direct analysis offood and beverage samples by ICP-MS was demonstrated by a number of groups in addition to the microfluidic chip approach previously described. ${ }^{48}$ Simulated saliva was used by Leufroy et $a .^{52}$ to determine the oral bioavailability of 8 elements ( $\mathrm{Al}, \mathrm{Cd}, \mathrm{Cu}, \mathrm{Hg}, \mathrm{Mn}, \mathrm{Pb}, \mathrm{V}$ and $\mathrm{Zn}$ ) in food samples. A mini-column was packed with the powdered sample and directly coupled to the nebuliser of the ICP mass spectrometer, which allowed continuous leaching profiles to be generated. The methodology was validated using CRMs and mass balance calculations. Gao and co-workers ${ }^{53}$ reported the direct determination of $\mathrm{Hg}$ in alcoholic beverages by using $\mathrm{UV}$ irradiation to generate volatile $\mathrm{Hg}$. This simple approach required no pre-treatment and significantly enhanced LODs. The determination of 16 trace and ultra-trace elements in milk was described by Husakova et al. ${ }^{54}$ The procedure involved the addition of oxalic acid and nitric acid to the milk to precipitate proteins and calcium. The resultant liquid phase could then be directly measured without problems caused by clogged nebulisers or spectral interferences from calcium.

A review article by Kleparnik ${ }^{7}$ summarised recent advances of $C E$ coupled to $M S$ for a wide range of applications. There was a strong focus on three specific MS techniques, namely ESI-MS, MALDI-MS and ICP-MS. A large suite of elemental speciation studies using CE-ICP-MS was reviewed.

4.1.2 Other mass spectrometry techniques. Stable iron isotope tracers were used by Chen et al. ${ }^{55}$ to study the long term uptake and distribution of Fe from dietary sources to investigate its role of $\mathrm{Fe}$ in neurodegenerative diseases. The researchers 
used ${ }^{57} \mathrm{Fe}$-spiked drinking water fed to adult rats over 16 weeks. Tissue samples were prepared for analysis using an ID approach with ${ }^{58} \mathrm{Fe}$ to calculate the natural $\mathrm{Fe}$ content and to enable deconvolution of the isotope ratio data. Measurements were performed using NTIMS for maximum isotope ratio precision. The results indicated that in absolute terms, only $0.000537 \pm$ $0.000076 \%$ of $\mathrm{Fe}$ in the brain was from dietary sources but accounted for $9.19 \pm 0.71 \%$ relative to the total $\mathrm{Fe}$ brain content.

\subsection{Atomic absorption spectrometry}

In general, advances in FAAS technology were not widely reported, with more focus on pre-concentration sample preparation. However, the determination of Cs has seen increasing demand with Miura and co-workers ${ }^{56}$ describing approaches for FAAS and ETAAS with Zeeman-effect background correction. Optimised FAAS conditions utilised potassium nitrate to control ionisation achieving a LOD of $0.04 \mathrm{mg} \mathrm{\textrm {L } ^ { - 1 }}$ whereas ETAAS employed potassium tungstate as a matrix modifier to attain an impressive LOD of $0.18 \mu \mathrm{g} \mathrm{\textrm {L } ^ { - 1 }}$. Both techniques were validated using food $\mathrm{RMs}$ with good recoveries obtained. $\mathrm{Li}$ et $a l .{ }^{57}$ reported the improved performance of a modified quartz tube atomiser for FAAS. The group coated the inner wall with nanometre-dimensions of $\mathrm{SiO}_{2}$ and demonstrated the improved performance with extended linear ranges and decreased characteristic concentrations for $\mathrm{Cu}$ and $\mathrm{Zn}$. Accuracy was also shown with the use of plant CRMs.

The use of furnaces with AAS was reported for the determination of $\mathrm{Ag}$. Gerondi and Arruda ${ }^{58}$ described the optimisation of TS-FF-AAS for the measurement of Ag. This technique has gained popularity in recent years due to improved sensitivity and cheap implementation. A respectable LOD of $0.15 \mu \mathrm{g} \mathrm{L}^{-1}$ for $\mathrm{Ag}$ was reported. A unique application of GF-AAS was reported by Gagne et al. ${ }^{\mathbf{1 2 3}}$ ] who were able to distinguish between $\mathrm{Ag}$ ions and $\mathrm{Ag}$ nanoparticles based on the atomisation temperature. The method was developed with standard solutions and the applicability was demonstrated using rainbow trout exposed to either ionic or nano-Ag.

Electrothermal volatilisation as a sample introduction technique received significant attention for a number of applications. A procedure for the determination of $\mathrm{Cr}$ in forensic samples was reported by Lech and Dudek-Adamska. ${ }^{59}$ The sample preparation (microwave acid digestion) and analytical parameters (ETAAS) were optimised and validated using RMs. The final method included the use of $\mathrm{Mg}\left(\mathrm{NO}_{3}\right)_{2}$ as a modifier with pyrolysis and atomisation temperatures of $1400{ }^{\circ} \mathrm{C}$ and $2500{ }^{\circ} \mathrm{C}$, respectively, which achieved an excellent LOD of $0.07 \mu \mathrm{g} \mathrm{\textrm {L } ^ { - 1 }}$. Zacharia et al. ${ }^{60}$ described the direct determination of $\mathrm{Pb}$ in wine by ETAAS. A graphite filter insert with a Pd-Mg matrix modifier was used to aid atomisation. A number of possible interferences were also investigated. The LOQ for the final method was $0.0025 \mathrm{mg} \mathrm{dm}^{-3}$ for wine samples.

The hyphenation of $H G$ with ETAAS using a flow injection approach was reported by Marval-Leon et al. ${ }^{\mathbf{6 1}}$ for the determination of Se in food samples. Experimental designs were applied to optimise the instrumental parameters. The resultant method achieved LODs for Se nearing MS-based techniques

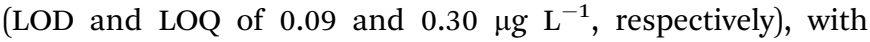
accuracy demonstrated through several food-based CRMs. A very different approach for the measurement of Se in food matrices was taken by de Lima and co-workers. ${ }^{23}$ The group produced polymers to specifically concentrate Se on-line prior to measurement by HG-AAS. Under optimised conditions, the

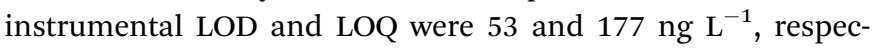
tively, which again is comparable to ICP-MS.

The use of HR-CS-AAS as a robust multi-element technique was demonstrated by Boschetti et al. ${ }^{62}$ who directly analysed wine samples for 10 trace elements for origin discrimination purposes. The method was shown to be comparable to ICP-OES. As with traditional AAS, a graphite furnace can also be used with HR-CSAAS. Ren et $a l .{ }^{63}$ reported the optimisation of HR-CS-GF-AAS for the measurement of $\mathrm{Cd}, \mathrm{Cr}$ and $\mathrm{Pb}$ in various food products. Rego and co-workers ${ }^{64}$ used this technique to determine $\mathrm{Pb}$ in medicinal plants by direct solid sampling. The LOD was $0.024 \mu \mathrm{g}$ $\mathrm{g}^{-1}$ on a dry mass basis using $\operatorname{Pd}\left(\mathrm{NO}_{3}\right)_{2}$ as a chemical modifier. Another example of direct analysis by HR-CS-GF-AAS was published by Rello et al. ${ }^{19}$ Dried urine spots were analysed for Mo and Ti after optimisation of the sample collection which required $500 \mu \mathrm{L}$ of urine applied to $17 \times 19 \mathrm{~mm}$ filter paper. The LODs for Mo and Ti were $1.5 \mu \mathrm{g} \mathrm{L}{ }^{-1}$ and $6.5 \mu \mathrm{g} \mathrm{L}^{-1}$, respectively, which are approaching clinically relevant levels.

The determination of non-traditional elements by HR-CS-GF$A A S$ via molecular absorption has seen a number of publications this year. ${ }^{65-67}$ Ozbek and Akman ${ }^{66}$ determined $\mathrm{F}$ in milk samples through the formation of $\mathrm{CaF}$ and detection on the $606.440 \mathrm{~nm}$ wavelength. The milk was directly added to the GF chamber at the same time as Ca. Although no modifier/tube coating was required, standard additions calibration was necessary due to matrix effects which varied between different milk types. The LOD for the optimised method was $0.26 \mathrm{ng}$ of $\mathrm{F}$ which is extremely favourable compared to other atomic spectroscopy techniques. In a second example, Ozbek and $\mathrm{Akman}^{65}$ reported the measurement of $\mathrm{S}$ in food products by the generation of carbon monosulfide in the gas phase and quantification using the $258.056 \mathrm{~nm}$ line. Additionally, direct analysis of solid samples was demonstrated using aqueous calibration standards. A good LOD (3.5 ng S) was observed and accuracy was tested through the use of CRMs. Fechetia et al. ${ }^{67}$ described the determination of $\mathrm{Cl}$ with HR-CS-GF-AAS in food samples by forming $\mathrm{AlCl}$ with the use of an $\mathrm{Al}-\mathrm{Ag}-\mathrm{Sr}$ mixed modifier and detection at the $261.418 \mathrm{~nm}$ wavelength. Acid digestion was performed using $\mathrm{HNO}_{3}, \mathrm{H}_{2} \mathrm{O}_{2}$ and $\mathrm{Ag}$ to precipitate the $\mathrm{Cl}$ as $\mathrm{AgCl}$ to prevent losses. The accuracy of the approach was demonstrated using CRMs, with lower LODs achieved than previously reported for ICP-OES.

\subsection{Atomic emission spectrometry and laser induced breakdown spectroscopy}

Following from the previous ASU review, ${ }^{1}$ little in the way of development was published with respect to AES or LIBS. The direct determination of $\mathrm{Ca}$ in beverages by AES utilising tungsten filaments from commercial light bulbs was reported by Santos 
et al. ${ }^{68}$ An in situ digestion with $\mathrm{HNO}_{3}$ and $\mathrm{H}_{2} \mathrm{O}_{2}$ was applied to remove excess organic matrix components followed by heating and atomisation steps. The approach was compared against ICP-OES using juice, coconut water and mineral water samples with no significant difference observed. The LOD and LOQ were 0.02 and $0.07 \mathrm{mg} \mathrm{L}^{-1}$, respectively.

A number of papers described the application of MIP-OES to environmental and food samples. ${ }^{69,70}$ Cerveny and co-workers ${ }^{69}$ reported a new approach to VG for $\mathrm{Hg}$ determination in water samples coupled to MIP-OES. A novel flow-through cell was used for electrochemical VG coupled to MIP-OES for $\mathrm{Hg}$ determination in water samples. Under optimised conditions, an LOD of $1.1 \mathrm{ng} \mathrm{mL}{ }^{-1}$ was achieved. Another example of MIP-OES was published by Tyburska and Jankowski ${ }^{70}$ who investigated the use of online HG for Se from alkaline digestions with preconcentration of the hydride on to solid-phase fibres (polydimethylsiloxane/Carboxen StableFlex). Thermal desorption was then applied to release the hydride directly into the MIP-OES instrument enabling a detection capability of $3.2 \mathrm{ng} \mathrm{mL}{ }^{-1}$. The approach was validated using a NIST SRM and compared to HG-ICP-OES.

\subsection{Atomic fluorescence spectrometry and vapour generation procedures}

A novel but indirect method for the determination of I by AFS was reported by Lu et al. ${ }^{71}$ Marine samples were acid digested then mixed with aqueous $\mathrm{Hg}^{2+}$ with the resultant $\mathrm{H}_{2} \mathrm{HgI}_{4}$ species extracted with IBMK. After phase separation, $\mathrm{KBH}_{4}$ was added to generate $\mathrm{Hg}$ vapour which was analysed by AFS. The optimised method was validated with CRMs and an excellent LOD of $0.038 \mu \mathrm{g} \mathrm{L}^{-1}$ was demonstrated which challenges those achievable by ICP-MS.

A number of papers ${ }^{26,72-74}$ have demonstrated the use of $A F S$ in combination with $V G$ techniques for speciation analysis. Chaparro et $a .^{72}$ created an automated on-line system for the determination of DMA and iAs as an alternative to chromatographic methods. A multi-syringe burette, with 3-way valves on each syringe, was used to deliver sample aliquots and reagents. After simple water extraction, the samples were either analysed directly for iAs content or reacted with peroxodisulfate followed by UV photo-oxidation for determination of iAs and DMA, with the difference accounting for DMA. Total As was determined on microwave acid digested samples. The use of HG with AFS enabled further improvements in sensitivity, with LODs for DMA and iAs of 0.09 and $0.47 \mu \mathrm{g} \mathrm{L}^{-1}$, respectively. Cui et al. ${ }^{73}$ developed and optimised a sensitive approach for the rapid determination of 3 organoarsenic compounds used as animal feed additives employing ASE for sample preparation and HPLC-HG-AFS analysis. Ultraviolet oxidation was used prior to HG-AFS to ensure the correct oxidation state of As. All experimental parameters were optimised resulting in fast extraction times and HPLC separation of the 3 species of interest within 20 min which achieved an LOD below $1 \mathrm{ng} \mathrm{mL}{ }^{-1}$. The methodology was successfully applied to animal liver samples. Olivares and co-workers $^{74}$ applied HPLC-HG-AFS for the speciation analysis of $\mathrm{Sb}$ in vegetables. An EDTA extraction process provided stabilisation of the $\mathrm{Sb}$ species prior to HPLC separation. The LODs for $\mathrm{Sb}^{\mathrm{V}}, \mathrm{Sb}^{\mathrm{III}}$ and $\mathrm{Me}_{3} \mathrm{Sb}$ were $0.08,0.07$, and $0.9 \mu \mathrm{g} \mathrm{L}^{-1}$, respectively. However, when applied to real samples of carrot, onion and spinach, the method only accounted for $50-70 \%$ of the total Sb. Hayashi et al. ${ }^{26}$ reported the use of HPLC-CV-AFS in the investigation of $\mathrm{Hg}$ speciation in biological samples after extraction with 2-mercaptoethanol. The method was validated using CRMs for $\mathrm{MeHg}$ and total $\mathrm{Hg}^{2+}$ and was applied to real seafood samples. In another work focused on $\mathrm{Hg}$ speciation, Zhang and co-workers ${ }^{75}$ demonstrated electrochemical VG using an L-cysteine modified graphite electrode. By applying different voltages, it was possible to separately quantify $\mathrm{MeHg}$ and $\mathrm{Hg}^{2+}$ in fish samples. Although LODs were not considered better than chemical VG techniques $\left(0.073\right.$ and $0.098 \mu \mathrm{g} \mathrm{L}^{-1}$ for $\mathrm{MeHg}$ and $\mathrm{Hg}^{2+}$, respectively), a high sample throughput $\left(30 \mathrm{~h}^{-1}\right)$ with reduced solvent use were distinct advantages.

The quantification of $\mathrm{Hg}$ species in terrestrial animal tissues from a former mercury mining site was presented by Nevado and co-workers. ${ }^{25}$ After an alkaline microwave assisted extraction and ethylation, headspace-SPME was applied using polydimethylsiloxane-coated fibres before GC separation and detection by AFS. The LODs for liver samples were $31.8 \mathrm{ng} \mathrm{g}^{-1}$ and $52.5 \mathrm{ng} \mathrm{g}^{-1}$ for $\mathrm{MeHg}$ and $\mathrm{Hg}^{2+}$, respectively, with accuracy checked using NCS ZC 71001 (beef liver) and BCR No 186 (pig kidney) as the sum of all $\mathrm{Hg}$ species, due to the lack of CRMs with $\mathrm{Hg}$ species data for terrestrial animals.

An interesting use of CV-AAS was reported by Kuta et al. ${ }^{76}$ for the determination of $\mathrm{Hg}$ in human urinary calculi from 489 samples taken from across the Czech Republic. Direct solid sampling was employed through the use of thermo-oxidation which enabled an LOD of $0.0001 \mathrm{mg} \mathrm{kg}^{-1}$. Additionally, a number of major $(n=3)$ and minor $(n=22)$ elements were measured by ICP-MS after acid digestion. The results showed a positive correlation between $\mathrm{Hg}$ and Se for samples with $\mathrm{Hg}$ levels above $2 \mathrm{mg} \mathrm{kg}^{-1}$ which added further evidence to the hypothesis that Se complexation can provide a mechanism for $\mathrm{Hg}$ detoxification.

\subsection{X-ray fluorescence spectrometry}

Developments in spectrometry were extensively reviewed in a separate Update published in JAAS. ${ }^{2}$

4.5.1 In vivo XRF spectrometry. Strontium, as the ranelate or citrate, is used to treat osteoporosis but its metabolism is poorly understood. To determine the accumulation of $\mathrm{Sr}$, to evaluate differences between the two agents and to verify the XRF spectrometric methodology, Wohl et al. ${ }^{77}$ measured $\mathrm{Sr}$ concentrations in bone. After administration to female rats for 8 weeks, bone $\mathrm{Sr}$ in the citrate-treated animals was approximately 100 times greater than in control animals and 35\% greater than in the ranelate-treated rats. However, it was then shown that the daily $\mathrm{Sr}$ doses had not been equivalent and that the deposition in bone was essentially the same for both groups.

4.5.2 Quantitative analysis. Samples recovered from remains associated with the ill-fated Franklin expedition to the Arctic in 1845 were analysed to determine the content of $\mathrm{Pb}^{78}$ Measurements in fragments of bone by SR-XRF, together with 
LA-ICP-MS for isotopic identification, showed the $\mathrm{Pb}$ to be distributed throughout the bone and to have consistent isotope ratios. The results did not support the theory that there was $\mathrm{Pb}$ exposure from the solder seals in tinned food.

Szczerbowska-Boruchowska $^{79}$ addressed quantification (mass per unit area) in XRF spectrometric analyses, as influenced by the thickness of a sample. It was shown that a $15 \mu \mathrm{m}$ thick sample is considered as 'thin' for Fe in most body tissues but as 'intermediate' for elements from $\mathrm{P}$ to $\mathrm{Ca}$. In addition, using dried samples further influences quantification and large errors were introduced if calculations based on thin samples were applied to those of intermediate thickness.

To determine concentrations of $A u$ in tumour and other body tissues following administration of gold-containing anti-cancer agents, Magana et $a l^{80}$ used EDXRF spectrometry to speedily obtain results. Specimens were dissolved in $\mathrm{KOH}$ and $35 \mu \mathrm{L}$ dried to form a thin sample for analysis. Results (5.8-41.3 ppm) were in agreement with those from other studies that had used INAA or ICP-MS and were available within 8 hours of specimen collection.

\section{Applications: Clinical and biological materials}

\subsection{Metallomics}

Developments in metallomics and speciation were extensively reviewed in a separate Update published in JAAS. ${ }^{6}$

Complexes containing Pt have an established role in the treatment of several types of cancer but their use is compromised by undesirable toxicity and renal tubular cells are particularly sensitive. Understanding the mechanism of damage could allow preventative or protective strategies to be developed. In line with the views of Grossl and Hartinger ${ }^{12}$ mentioned in Section 1, researchers with differing expertise worked together in a project to investigate Pt-protein complexes in renal proximal tubular epithelial cells. For this work, MorenaGordaliza et $a l .{ }^{81}$ first separated proteins by SDS-PAGE under non-reducing conditions and located those containing Pt by LA-ICP-MS of the dried gels. The same gels were then used to identify the proteins by trypsin digestion of the spots, followed by nano-HPLC-ESI-linear ion trap-Fourier transform ion cyclotron resonance analyser-MS/MS. These techniques were applied to the analysis of serum and renal tubule cells from a rat given cisplatin. The Pt was associated with $\alpha_{2}$-macroglobulin, albumin, transferrin and haemoglobin in serum and in cultured pig kidney proximal tubular epithelial cells.

There is epidemiological evidence for Se having a protective effect against certain human cancers. Consequently, investigations of Se metabolism in cancer cells, to understand this activity, are ongoing. Weekley et al. ${ }^{9}$ noted that the necessary sample preparation for HPLC-ICP-MS and ES-MS/MS could affect speciation analysis and drew attention to studies in which SRXAS and XFM techniques were applied, as these require minimal pre-treatment of samples. They concluded that organic Se metabolites are distributed throughout human lung cancer cells while iSe metabolites are compartmentalised and are in association with $\mathrm{Cu}$.
Could investigations of Se metabolism in yeast be starting to diminish? Unlike the last few years, there is little to report. One major centre for this work is at Pau and from there Arnaudguilhem et $a .^{82}$ used RP-HPLC for large scale separation of Se metabolites with identification by ES hybrid quadrupole trap/ Orbitrap MS. This gave higher separation efficiency than the previously used HILIC mode. With this procedure, 64 metabolites were detected which included $30 \mathrm{Se}-\mathrm{Se}$ or Se-S conjugates, 14 selenoethers and 21 that were previously unreported. Of the latter, nine were identified using multi-stage high mass accuracy MS.

Cellular $\mathrm{Cu}$ transporters are crucial to the metabolism of this metal with defects being responsible for the inherited disorders that cause $\mathrm{Cu}$ deficiency and toxicity. While these have been studied extensively in intestinal and hepatic cells, little is understood regarding $\mathrm{Cu}$ transport systems in the brain. Davies et $a l .{ }^{83}$ quantified $\mathrm{Cu}$ concentrations and the distribution and localization of the proteins Cu-transporter 1, Atox1, ATP7A and ATP7B in different regions of human brain using ICP-MS, Western blot and immunohistochemistry. They reported significant relationships between $\mathrm{Cu}$ transporter levels and brain $\mathrm{Cu}$ concentrations. The substantia nigra contained twice as much $\mathrm{Cu}$ than was found in other brain regions. This data regarding $\mathrm{Cu}$ regulation in the human brain points to mechanisms by which brain Cu levels may be altered, with relevance to neurological disease.

Previous Updates ${ }^{\mathbf{8 4 , 8 5}}$ have referred to the work of Michalke and colleagues in which concentrations of Se in paired serum and CSF specimens were compared to investigate whether there may be positive uptake into neural tissue. Following from the earlier studies, further work looking at $\mathrm{Se}^{\mathbf{8 6}}$ and $\mathrm{Mn}^{\mathbf{8 7}}$ in serum and CSF has been reported. Anion exchange separation and ICP-MS methods were carefully validated for Se speciation on paired serum and CSF samples from 24 subjects with no neurological dysfunction. Additional species were detected compared with their earlier work. In decreasing concentration order, total Se, Se-albumin, $\mathrm{Se}^{\mathrm{IV}}$, selenoprotein $\mathrm{P}$, GPx, thioredoxin reductase and SeMet were found in serum. Other species were present at very low concentrations in some samples. All except SeMet were also detected in CSF but, after total Se $\left(\right.$ median $\left.=0.86 \mu \mathrm{g} \mathrm{L}^{-1}\right)$, selenoprotein $\mathrm{P}$ was present with the greatest concentration $\left(0.47 \mu \mathrm{g} \mathrm{L}^{-1}\right)$. The relationship between serum and CSF concentrations, expressed in molar units, was consistent except for GPx and thioredoxin reductase and it was suggested that there could be facilitated diffusion across the blood-brain barrier or additional synthesis of these two anti-oxidant enzymes in the brain. At total serum Mn concentrations below $1.5 \mu \mathrm{g} \mathrm{L}^{-1}$, Mn was protein-bound (transferrin and albumin) but, at higher concentrations, an increasing proportion was found as Mn-citrate. In corresponding CSF specimens, total Mn concentrations were approximately half those in the serum. However, the CSF protein-bound Mn was only about $10 \%$ that of the serum with citrate as the major species. The inference of these results was that Mn-citrate in serum is a marker of total $\mathrm{Mn}$ in CSF (and brain) and for risk of Mn-dependent neurological disorders. 
A number of novel approaches or adaptations to established procedures for elemental speciation were introduced during this review period. The concept of performing initial reactions, mixing and extraction of Se metabolites in yeast cells on a single chip $^{22}$ was described in Section 3.2. Arsenic species are usually separated and determined by HPLC and ICP-MS methods but Takeuchi and colleagues ${ }^{25,88}$ proposed to use GC-MS when monitoring occupational exposure to iAs. Arsenic compounds in urine were simply derivatised with 2,3-dimercapto-1-propanol prior to the measurement. Detection limits for $\mathrm{As}^{\mathrm{III}}, \mathrm{As}^{\mathrm{V}}$ and MMA were given as $0.2 \mu \mathrm{g} \mathrm{L}^{-1}$ and the recoveries were close to $100 \%$. In another twist to normal practice, de Souza et al. ${ }^{89}$ separated $\mathrm{iHg}, \mathrm{MeHg}$ and EtHg in plasma by HPLC, rather than by GC. A solution with mercaptoethanol, L-cysteine and $\mathrm{HCl}$ was used for extraction and taken for HPLC on a $\mathrm{C}_{8}$ RP column with $3 \% \mathrm{MeOH}$ and $97 \%$ (0.5\% 2-mercaptoethanol-0.05\% formic acid) as the mobile phase. Measurement of $\mathrm{Hg}$ was performed by CV-ICP-MS and the LODs were 12,4 and $5 \mathrm{ng} \mathrm{L}^{-1}$ for $\mathrm{iHg}$, $\mathrm{MeHg}$ and EtHg, respectively. The accuracy was established by measurement of blood CRMs and the method applied to a study of $\mathrm{MeHg}$ concentrations in plasma samples from riverside populations in Brazil. Zhang et al. ${ }^{75}$ adopted a non-chromatographic approach to speciate $\mathrm{iHg}$ and $\mathrm{MeHg}$ in seafoods. In this innovative procedure, a feature of the electrolytic VG from an L-cysteine-modified graphite electrode was exploited. Only $\mathrm{Hg}^{2+}$ vaporised at a current of $0.2 \mathrm{~A}$, while at $2.2 \mathrm{~A}$, both $\mathrm{Hg}^{2+}$ and $\mathrm{MeHg}$, were released. The method was validated by analysis of CRM DORM-2. Detection limits were 0.098 and $0.073 \mu \mathrm{g} \mathrm{L}^{-1}$, and repeatability was $3.2 \%$ and $4.7 \%$, for $\mathrm{Hg}^{2+}$ and $\mathrm{MeHg}$, respectively. Speciation of $\mathrm{Sb}$ is not often carried out on biological samples but Olivares et al. ${ }^{74}$ elected to do so for analysis of spinach, carrots and onions. While separation of $\mathrm{Sb}^{\mathrm{III}}, \mathrm{Sb}^{\mathrm{V}}$ and $\mathrm{Me}_{3} \mathrm{Sb}$ and measurement were accomplished using standard HPLC and HG-AFS conditions, it was necessary to develop a suitable extraction procedure. Of the techniques examined, the best results were obtained when using $10 \mathrm{mmol} \mathrm{L}^{-1}$ EDTA at pH 2.5 as this afforded highest extraction rates and also prevented oxidation of $\mathrm{Sb}^{\mathrm{III}}$. However, despite all the work on extraction, recoveries of total $\mathrm{Sb}$ were only between 50 and $70 \%$. The LODs and RSDs for $\mathrm{Sb}^{\mathrm{III}}, \mathrm{Sb}^{\mathrm{V}}$ and $\mathrm{Me}_{3} \mathrm{Sb}$ were $0.07,0.08$ and $0.09 \mu \mathrm{g} \mathrm{L}^{-1}$, and 5.2, 5.0 and 4.7\%, respectively. Associated with the concerns about metal hip prostheses is recent work to evaluate potential toxicity of the Co, $\mathrm{Cr}$ and other elements released from these devices. The contribution from Kerger et al. ${ }^{\mathbf{9 0 9 1}}$ was to set up a method for Co speciation in serum and to apply the procedure to a study in which volunteers ingested 1 mg Co day ${ }^{-1}$ for 90 days. Albumin-bound Co, cyanocobalamin (vitamin $\mathrm{B}_{12}$ ) and small molecular Co fractions were separated by SEC with ICP-MS detection. Most Co in serum was bound to albumin, approximately $80-95 \%$.

Isotopic fractionation may be viewed as a special example of elemental speciation. In Section 3.1, a procedure to determine ${ }^{65} \mathrm{Cu}:{ }^{63} \mathrm{Cu}$ isotope ratios in urine, spotted onto filter paper, was discussed as a possible diagnostic test for Wilson's disease. In a second report from the same department, ${ }^{92} \mathrm{Cu}$ isotopes were measured in serum samples from Wilson's disease patients, patients who had undergone bariatric surgery, infants and healthy subjects with a view to early diagnosis of Wilson's disease, i.e., soon after birth. Samples were passed though a strong anion exchange resin, AG-MP-1 to separate out the $\mathrm{Cu}$ and the isotopes were measured by MC-ICP-MS. The authors concluded that a combination of $\mathrm{Cu}$ concentration values and $\mathrm{Cu}$ isotopic information allowed classification of Wilson's disease patients, infants and controls into different groups, while the use of concentration values alone was not sufficient for this purpose. These two reports presented extremely promising results and further studies were indicated. Unfortunately, the requirement for an MC-ICP mass spectrometer, or similar instrumentation, makes it unlikely that work will progress quickly or that the tests will be widely available.

\subsection{Imaging: LA-ICP-MS and XRF spectrometry}

In the past year, the application of imaging techniques for biological materials has continued to grow with some diverse studies reported. Developments in laser ablation technology were not as prolific as in previous ASU Reviews. However, Wu and Becker ${ }^{93}$ described the use of laser microdissection equipment with custom made chambers combined with ICP-MS. This resulted in increased spatial resolution for bioimaging applications with enhanced transport efficiency and washout times. Lear et al. ${ }^{94}$ reported improved analytical figures of merit for LAICP-MS for $\mathrm{Ca}, \mathrm{Co}, \mathrm{Cu}, \mathrm{Fe}, \mathrm{Mn}$ and $\mathrm{Zn}$ using $\mathrm{H}_{2}$ reaction gas to reduce the interference from polyatomic species. This enabled smaller beam sizes to be used to increase spatial resolution approaching single cell dimensions.

Histological stains have long been used for the visualisation of cell structures by light microscopy analysis. Reifschneider et al. ${ }^{95}$ demonstrated how LA-ICP-MS imaging could be used in parallel with haematoxylin and eosin stains, which contain $\mathrm{Al}$ and $\mathrm{Br}$, respectively. This approach was applied to several different tissue types and enabled enhanced resolution when compared to microscopy alone. It was shown that the stain process did not affect the elemental distribution by examining Pt in tumour sections after treatment with cisplatin, further extending the range of application. Stepankova and coworkers $^{96}$ investigated the spatial distribution and quantification of elements within human kidney stones which is challenging due to differences in morphology, composition and homogeneity. They tackled this issue by preparing an in-house standard from powdered human kidney stones and applied a number of imaging techniques (LA-ICP-OES, LA-ICP-MS, LIBS and LA-LIBS) to determine the optimum analytical conditions for this matrix type which could provide important information on the formation and growth of the stones.

A number of articles describing the use of imaging techniques for archaeological and forensic applications have been published ${ }^{78,97,98}$ with implications for interpretation of the data. Herwartz and co-workers ${ }^{97}$ used LA-ICP-MS to investigate REEs in detail across a large selection of fossil bones from a range of different ages. Their results indicated that REE patterns must be treated with caution due to the influence of intra-bone fractionation and environmental conditions. Kohn et al. ${ }^{\mathbf{9 8}}$ analysed tooth samples from modern herbivores, omnivores and 
carnivores from Idaho, USA, by LA-ICP-MS, to determine the validity of using elemental profiling for the study of diet in archaeological remains. The concentration of minor and trace elements $(n=69)$ was measured in 3 layers of the tooth, namely enamel, primary dentine and secondary dentine. However, the results indicated that the influence of dust and soil particles played a large role in the elemental composition making it difficult to infer dietary information from historical/forensic samples without further data. However, the results indicated that the influence of dust and soil particles played a large role in the elemental composition making it difficult to infer dietary information from historical/forensic samples without further data. A study ${ }^{78}$ utilising both LA-ICP-MS and XRF spectrometry to investigate the $\mathrm{Pb}$ distribution in bones from the failed Franklin expedition in 1845 was reported. The bulk distribution of $\mathrm{Pb}$ was examined by XRF spectrometry whilst LA-ICP-MS was used to gain isotopic information over smaller regions. The results appeared to contradict the commonly accepted hypothesis of $\mathrm{Pb}$ poisoning from poorly soldered food cans.

The analysis of metalloproteins by combining multiple techniques for protein separation and identification has been reported. ${ }^{81,99}$ Morena-Gordaliza et $a l .{ }^{81}$ developed a complex method for the identification of Pt-bound proteins using LAICP-MS to identify Pt-containing regions in 2D electrophoresis gels followed by in-gel digestion and nHPLC-ESI-MS/MS analysis. The approach was applied to real serum samples from a cisplatin-treated rat and cultured renal proximal tubule epithelial cells incubated with cisplatin. The results identified a number of proteins known to associate with Pt which was consistent with previous literature, but the method was not sensitive enough to unequivocally identify Pt-peptides and therefore Pt-proteins in real samples. This problem was overcome by Bianga and co-workers ${ }^{99}$ who used a similar approach, combining LA-ICP-MS imaging of 2D electrophoresis gels with ICP-MS and ESI-MS/MS, for storage protein identification in Sefortified food products. Regions of high Se-content were identified by LA-ICP-MS and selectively removed from the gel. After trypsin digestion, the peptides were separated by HPLC with split-flow injection into ICP-MS and ESI-MS/MS for Se-selective identification. The methodology demonstrated a family of Serich storage proteins, namely glutenins, and, for the first time, Se substitution in cysteine as well as methionine.

A review article for MS imaging in bio-samples was published by Lanni et al. ${ }^{10}$ which highlighted the use of other MS based technologies for bio-imaging. MALDI and SIMS were identified as the predominant approaches used for micro-bio-analytical studies. Innovations with MALDI have increased the applicability for investigations of single cells and organelles. Recent developments with ion probe technology have enabled SIMS to achieve greater sensitivity and can reach spatial resolutions at the sub-cellular level. Moore et al. ${ }^{\mathbf{1 0 0}}$ described the application of nanoSIMS to the distribution analysis of As in rice. The instrumentation has superior resolution to traditional SIMS and was able to differentiate As at the sub-cellular level. Furthermore, concomitant images for P, S and Si were simultaneously obtained leading to identification of mechanisms of As mobilisation in rice. Chang and co-workers ${ }^{\mathbf{1 0 1}}$ described an improved approach to freeze-fracture sample preparation for slicing tissue and cell samples. Powerful magnets were used to provide a consistent and uniform force, enabling enhanced preservation of the cell structures and improved reproducibility. The approach was demonstrated using HepG2 cells labelled with CdTe quantum dots to visualise via fluorescence and additionally with TOF-SIMS to generate ion images for $\mathrm{Ca}, \mathrm{Cd}$ and total ion count. The preparation method could be applied to other analytical techniques.

The increased interest in the fate of silver nanoparticles in biological samples has stimulated a study into their uptake and distribution behaviours. Draude et al. ${ }^{\mathbf{1 0 2}}$ applied TOF-SIMS and laser-SNMS to investigate this effect in macrophage cells. Silver nanoparticles were found to be incorporated with some degree of agglomeration observed in 2D and 3D images generated with laser-SNMS.

The use of X-rays for imaging applications has shown some developments, with Szczerbowska-Boruchowska ${ }^{79}$ demonstrating the effects of sample thickness for quantitative XRF spectroscopic analysis in various tissue types. The theoretical evaluation was validated using human brain samples and a powdered bovine liver SRM; discrepancies of up to $45 \%$ in the concentrations could occur if thickness was not taken into account. Weekley et al. ${ }^{9}$ published a review of Se metabolism in relation to cancer studies but highlighted the lengthy sample preparation procedures and loss of distribution data within tissues using traditional hyphenated techniques. Therefore the group considered X-ray techniques as an alternative for Se speciation analysis and to gain spatial resolution for imaging. Results were presented for Se distribution in human lung cancer cells by XFM, Se species in cells using XANES and EXAFS and Se-bound proteins in cell lysates by XFM after electrophoretic separation. The combination of XAS and XFM techniques provided complementary data and demonstrated potential advantages over traditional approaches.

\subsection{Multielement applications}

5.3.1 Biological fluids. Following revelations of increasingly greater failure rates of hip prostheses, requirements for monitoring patients have been introduced in several countries. Associated with this, the number of publications describing measurements of the concentrations of metals such as Co, Cr, Mo, Ni and Ti in samples such as blood, serum, urine and erythrocytes, has also increased.

In addition to investigations of patients with artificial hips, ${ }^{39-42}$ other subject groups with metal implants studied were those with steel bars inserted into the chest to treat pectus excavatum (sunken chest), ${ }^{43}$ instrumented arthrodesis (spinal fusion) ${ }^{\mathbf{4}}$ and metallic spinal disc replacement. ${ }^{45}$ Metal concentrations were elevated above normal levels by up to 10 -fold following surgery and remained increased but, in those with failing hip prostheses, blood concentrations of Co and Cr may be more than $100 \mu \mathrm{g} \mathrm{L}^{-1}$ compared with less than $2 \mu \mathrm{g} \mathrm{L}^{-1}$ in healthy subjects. The concentrations of Co in blood are directly correlated to the amount of implant wear. ${ }^{\mathbf{1 0 3}}$

Roos et al. ${ }^{\mathbf{1 0 4}}$ measured concentrations of a suite of metals in plasma and CSF from 17 patients with a degenerative disorder of 
motor neurons, amytrophic lateral sclerosis. Statistically significant increases in the concentrations of $\mathrm{Al}, \mathrm{Cd}, \mathrm{Co}, \mathrm{Cu}, \mathrm{Pb}$, $\mathrm{U}, \mathrm{V}$ and $\mathrm{Zn}$ were found in the samples of CSF. These were also greater than in the plasma and it was proposed that there is positive uptake into the spinal fluid, which may be relevant to the cause of the nerve cell degeneration.

The concentrations of As metabolites in saliva collected from patients with acute promyelocytic leukaemia treated with $\mathrm{As}_{2} \mathrm{O}_{3}$ were measured by Chen et al. ${ }^{105}$ using HPLC and ICP-MS. While MMA, MMAV, DMA and $\mathrm{As}^{\mathrm{V}}$ were found, $\mathrm{As}^{\mathrm{III}}$ was the predominant species at around $72 \%$ of the total. The authors proposed that salivary As may be a useful clinical biomarker during treatment but data from a study over just three days with only nine patients is inadequate to reach a safe conclusion.

Maximum bioaccessibility of $\mathrm{Al}, \mathrm{Cd}, \mathrm{Cu}, \mathrm{Hg}, \mathrm{Mn}, \mathrm{Pb}, \mathrm{V}$ and $\mathrm{Zn}$ from seafoods was assessed by Leufroy et al. ${ }^{52}$ who set up a continuous leaching procedure. The method involved passing artificial saliva or gastric juice through a column with a powdered food sample that was directly connected to an ICP-MS nebuliser. However, it is difficult to understand how this would give any information that is representative of real digestion since the experiment involved artificial fluids and atypical (powdered) foods in an entirely artificial set-up.

In a study to investigate normal exposure to potentially toxic environmental agents, Steuerwald et al. ${ }^{37}$ measured the concentrations of 21 elements in urine samples from women with endometriosis, by ICP-QMS and obtained unrealistically high concentrations of Pt and Se. Noting a previous report of how $G^{2+}$ interferes with the measurement of Se, it was established that the subjects included in this study had been given a Gd-containing contrast agent for pelvic MRI. Further analysis of these urine samples by SF-ICP-MS revealed a number of Gd species, chlorides, argides and oxides, with $\mathrm{m} / \mathrm{z}$ ratios that interfere with the measurement of Pt.

These observations highlight the importance of having accurately determined reference ranges for trace elements in biological specimens and the two surveys of normal concentrations in urine ${ }^{17,18}$ were noted above.

5.3.2 Tissues, hair and nails. Wilson's disease is an inherited disorder of copper metabolism that primarily affects the brain and/or liver. Litwin et al. ${ }^{\mathbf{1 0 6}}$ considered whether other metals might be involved also and measured $\mathrm{Cu}$. Fe, $\mathrm{Mn}$ and $\mathrm{Zn}$ concentrations in four areas of the brain from 12 patients and 5 control subjects. They found that the patient samples had significantly raised $\mathrm{Cu}$ in all areas, $41.0 \pm 18.6 \mu \mathrm{g} \mathrm{g}^{-1} c f .5 .4 \pm$ $1.8 \mu \mathrm{g} \mathrm{g}^{-1}$, and Fe in the nucleus dentate, $56.8 \pm 14.1 \mu \mathrm{g} \mathrm{g}^{-1} c f$. $32.6 \pm 6.0 \mu \mathrm{g} \mathrm{g}^{-1}$. It was also noted that concentrations of $\mathrm{Cu}$ and $\mathrm{Fe}$ increase with disease duration.

Deposits of Fe in brain are a feature of neurodegenerative conditions such as Alzheimer's and Parkinson's diseases, and may be involved in the aetiology of these disorders. Chen et al. ${ }^{55}$ added the stable isotope ${ }^{57} \mathrm{Fe}$ to the drinking water of adult rats for 4 months and used NTIMS to measure both the total Fe and ${ }^{57} \mathrm{Fe}$ in brain. The uptake of dietary $\mathrm{Fe}$ was calculated to be $0.000537 \pm 0.000076 \%$, which was said to be greater than previously reported, but whether this is a factor in neurodegeneration is unclear.
As it has been repeatedly reported in previous Updates, one problem associated with the use of hair as a marker of trace element exposure or absorption, is that of external contamination. Many washing procedures have been described but none are able to reliably remove surface contamination without extraction from within the hair. Using TOF-SIMS, Kempson and Skinner ${ }^{\mathbf{1 0 7}}$ compared internal and external concentrations of $\mathrm{Ca}$, $\mathrm{Fe}, \mathrm{Mg}$, $\mathrm{Na}$ and $\mathrm{Zn}$ following two washing protocols and confirmed that removal effects are different among elements and that there is no consistence with respect to internal and external losses during the procedures.

\subsection{Progress for individual elements}

5.4.1 Aluminium. Novel applications of ICP-MS to trace element analysis in the clinical setting are reported every review period. Haematoxylin-eosin (H\&E) stains, used to visualise cellular structures in histopathological diagnosis of different diseases, contain both $\mathrm{Al}$ and $\mathrm{Br}$. Reifschneider et al. ${ }^{95}$ exploited this characteristic to gain additional dimensional visualisation of cellular structures by determining $\mathrm{Al}$ and $\mathrm{Br}$ in $\mathrm{H} \& \mathrm{E}$ stained tissue sections using LA-ICP-MS with DRC. They used the method to examine stained sections of appendix, lymph node, fallopian tube and oesophageal tumour and obtained $\mathrm{Al}$ and $\mathrm{Br}$ images of the sections with a resolution down to $10 \mu \mathrm{m}$. Unstained samples showed no significant background signal for $\mathrm{Al}$ or $\mathrm{Br}$ which demonstrated the successful removal of polyatomic and isobaric interferences by use of collision/reaction cell technology. They suggested that the method offered considerable potential for providing additional cellular structural information above that provided by conventional H\&E staining alone. The authors also used the same approach to visualise $\mathrm{Pt}$ distribution in tumour tissue sections from a patient undergoing cisplatin chemotherapy.

5.4.2 Antimony. Filella and colleagues ${ }^{14}$ opened their review on the determination of $S b$ in biological fluids with a somewhat controversial statement, suggesting that the merit of determining elements in excreted biological fluids to assess exposure was still uncertain. The group undertook a critical evaluation of published methods and analytical data for the quantitative determination of Sb in milk, urine and saliva. They focused on objective evaluation of the methodology, establishing ranges of $\mathrm{Sb}$ concentration in the biological fluid considered and evaluating the value of the data in assessing occupational and environmental exposure. They noted that much of the reported data was not supported by analysis of CRMs and that many reported concentrations were close to the LOD of the technique employed. The authors concluded that reference ranges for $\mathrm{Sb}$ in biological matrices were difficult to define. They also considered that urinary $\mathrm{Sb}$ determination was justified in examining occupational and environmental exposure to localised sources such as mines and smelters, which seemed to contradict their opening statement but which was reassuring to members of this review team who had spent much of their careers developing such analytical methods to protect the health of the UK workforce. Liu $^{\mathbf{1 0 8}}$ also emphasised the need for biological monitoring of $\mathrm{Sb}$ exposure in occupational settings. 
The author described a sample pre-treatment to extract $\mathrm{Sb}$ from the urine matrix using supercritical $\mathrm{CO}_{2}$ extraction with thenoyltrifluoroacetone as the chelating agent. Quantitative extraction was achieved at $60{ }^{\circ} \mathrm{C}$ and 17.2 MPa pressure and $\mathrm{Sb}$ determined using ETAAS with a $\mathrm{Pd}\left(\mathrm{NO}_{3}\right)_{2}-\mathrm{Mg}\left(\mathrm{NO}_{3}\right)_{2}$ mixed chemical modifier. The method was validated by analysing spiked human urine samples and CRMs.

5.4.3 Arsenic. There is often a feeling of déjà-vu when reading through papers in preparation for writing this review. This was certainly the case with the publication of Lovreglio et al. ${ }^{109}$ describing the factors influencing urinary excretion of As species. They collected urine samples at regular time intervals from 6 male volunteers over a 5 month period and determined total As and As species using HGAAS and HPLC-ICP-MS. Speciation analysis was performed on all urine samples having a total As concentration of $35 \mu \mathrm{g} \mathrm{L}^{-1}$ or greater (a Biological Exposure Index value set by the ACGIH). They observed that high urinary As excretion was associated with intake of seafood and/or red wine up to $72 \mathrm{~h}$ before urine collection. The results of the study led the authors to conclude that urinary As speciation was essential when performing biological monitoring of occupational exposure to As if correct interpretation of the results was to be ensured. Exactly the same conclusion was reached some years ago by researchers at the Occupational Medicine and Hygiene Laboratory of the UK Health and Safety Executive who carried out similar dietary studies (see Arbouine, M. W., and Wilson, H. K. (1993)). The effect of seafood consumption on the assessment of occupational exposure to arsenic by urinary arsenic speciation measurements. J. Trace Elem. Electrolytes Health Dis., 6, 153-160. A human study by Molin et al. ${ }^{110}$ took urinary As speciation to 'another level' with a complete speciation pattern of urinary As following intake of blue mussels. The researchers used a combination of RP, anion-exchange and cation-exchange HPLC coupled with ICP-MS to quantitatively determine fifteen distinct As species. Arsenobetaine (60\%) and DMA (21\%) represented the major proportion of total As, whilst thio-arsenicals represented $10 \%$ and iAs less than $7 \%$. They noted that generation of thio-arsenic species was significantly correlated with excretion of $\mathrm{AB}$. Methods continue to be developed for As speciation in biological matrices. In the method described by Chaparro et al. ${ }^{72}$ multi-syringe FI was coupled with HG-AFS for the determination of DMA and iAs species. A UV lamp was used for on-line photo-oxidation of DMA prior to quantitative determination of total As and a by-pass flow took the digested sample directly to the HG-AFS system for determination of iAs. The concentration of DMA was calculated by subtraction of the iAs fraction from the total As measurement. Reported LODs were $0.09 \mu \mathrm{g} \mathrm{L}^{-1}$ and $0.47 \mu \mathrm{g} \mathrm{L}^{-1}$ for DMA and iAs, respectively. The method was validated by analysing BCR-627 tuna muscle CRM.

Problems associated with the use of saliva as a sample for monitoring trace element status have been previously highlighted in these ASU Reviews. Nevertheless, there continues to be interest in the use of this matrix as a biomarker for monitoring various toxic elements. Chen et al. ${ }^{105}$ investigated the merit of determining As species in saliva as a clinical biomarker for patients undergoing $\mathrm{As}_{2} \mathrm{O}_{3}$ chemotherapy for acute promyelocytic leukaemia. Saliva samples were collected from patients over three consecutive days. An HPLC-ICP-MS method was used to quantitatively determine As species, of which $\mathrm{As}^{\mathrm{V}}$ was predominant, being $72 \%$ of total salivary As. The authors noted that, following daily As infusion, the percentage of methylated species decreased significantly, which they suggested was due to saturation of the methylation process. They concluded that salivary As was an appropriate biomarker for monitoring As in patients undergoing $\mathrm{As}_{2} \mathrm{O}_{3}$ treatment.

Hair As is another biomarker that has to be interpreted with caution owing to the recognised problem of external contamination and the effectiveness of washing procedures. Pineiro ${ }^{30}$ introduced the concept of a 'green' sample pre-treatment, presumably one that is environmentally friendly, in their method to determine As species in human hair using HPLC coupled with ICP-MS. The method employed pressurised hot water extraction, in which dried hair was mixed with diatomaceous earth as a dispersing agent and extracted with $\mathrm{CH}_{3} \mathrm{COOH}$ at $100{ }^{\circ} \mathrm{C}$ and $1500 \mathrm{psi}$. With optimised conditions for extraction, LODs of $6.3 \mathrm{ng} \mathrm{g}^{-1}$ for $\mathrm{As}^{\mathrm{III}}$ and $50.3 \mathrm{ng} \mathrm{g}^{-1}$ for $\mathrm{As}^{\mathrm{V}}$ were reported. The method was validated by analysing GBW07601 human hair CRM.

Past reviews have highlighted the environmental As contamination problem in regions of India, but much less attention has been paid to a similar problem in Latin America. McClintock et al. ${ }^{13}$ highlighted this issue, reporting that at least 4.5 million people in Latin America are exposed to high concentrations of As from contaminated drinking water sources. They conducted a systematic review of publications to explore the current understanding of the problem and its health consequences to populations of Latin America. They noted that genetic polymorphism of proteins associated with As metabolism were specifically implicated in a number of adverse health outcomes and concluded that future targeted studies would help achieve effective and timely mitigation efforts.

5.4.4 Chromium. The significance of $\mathrm{Cr}$ in blood glucose control and diabetes is still under debate. In order to monitor $\mathrm{Cr}$ nutritional status, Cieslak et al. ${ }^{47}$ developed a highly sensitive method for the determination of total Cr in whole blood using ICP-DRC-MS. Interferences on $\mathrm{Cr}$ were minimised with a combination of kinetic energy discrimination and $\mathrm{He}$ as collision-cell gas. The researchers determined $\mathrm{Cr}$ levels in blood samples from healthy adults collected in 'trace element-free' EDTA collection tubes and a reference range of 3.92-7.48 nmol $\mathrm{L}^{-1}$ was reported.

Most methods described in the clinical section of this ASU review relate to the determination of trace elements in tissues and biological fluids from living subjects. Work by Lech and DudekAdamska, ${ }^{59}$ however, described optimised conditions for the determination of total $\mathrm{Cr}$ in wet-digested samples from human post mortem tissues using ETAAS. Five procedures were examined using different combinations of chemical modifier and microwave digestion programmes. They concluded that wet digestion followed by ETAAS with $\mathrm{Mg}\left(\mathrm{NO}_{3}\right)_{2}$ as chemical modifier and pyrolysis and atomisation at $1400{ }^{\circ} \mathrm{C}$ and $2500{ }^{\circ} \mathrm{C}$, respectively, gave the best results for analysis of CRMs and 
spiked samples. An LOD of $0.07 \mu \mathrm{g} \mathrm{L^{-1 }}$ which was considered acceptable for determining $\mathrm{Cr}$ at reference levels and those found in cases of acute and chronic Cr poisoning.

5.4.5 Cobalt. In recent years considerable attention has been paid to the study of serum concentrations of trace elements released from metal-on-metal hip surfaces and total hip replacements. In the work described by Gornet et al., ${ }^{45}$ this interest was extended to the relatively new metal-on-metal total disc replacement treatment for degenerative lumbar disc disease. The researchers used HR-ICP-MS to determine serum Co and $\mathrm{Cr}$ levels in 24 patients with Co-Cr alloy total disc replacements. Reported LODs for the method were $0.015 \mathrm{ng} \mathrm{mL}^{-1}$ and $0.06 \mathrm{ng}$ $\mathrm{mL}^{-1}$ for $\mathrm{Cr}$ and Co, respectively. Serum Co levels peaked at $1.03 \mathrm{ng} \mathrm{mL}^{-1}$ six months post operation and serum Cr levels were $0.6 \mathrm{ng} \mathrm{mL}^{-1}$ at the same time point. Both elements remained elevated in serum over a 36 month post-operative time frame. The authors noted that these concentrations were the same order of magnitude as those previously reported for hip replacement therapy. Bernstein et al. ${ }^{39}$ emphasised the need for long-term studies of metal ion release in patients having undergone metal-on-metal total hip arthroplasty. They reported the results of a seven to thirteen year follow up of 163 patients having undergone second generation total hip arthroplasty. Blood samples were collected and total Co and Cr concentrations determined using ICP-MS. The researchers reported that blood Co peaked at $2.9 \mu \mathrm{g} \mathrm{L}^{-1}$ four years post-operation and $\mathrm{Cr}$ peaked at $0.75 \mu \mathrm{g} \mathrm{\textrm {L } ^ { - 1 }}$ five years post-operation. Levels subsequently declined to $2 \mu \mathrm{g} \mathrm{L^{-1 }}$ and $0.5 \mu \mathrm{g} \mathrm{L^{-1 }}$ for Co and $\mathrm{Cr}$, respectively.

Kerger et al. ${ }^{\mathbf{9 0 , 9 1}}$ described a method for the determination of Co species in human serum. Size-exclusion chromatography was used to separate large $M_{\mathrm{r}}$ species (albumin-Co) from cyanocobalamin, glutathione-Co and free Co species for quantitative determination using ICP-MS. An LOD of $0.037 \mu \mathrm{g} \mathrm{L} \mathrm{L}^{-1}$ was reported for undiluted serum. The authors investigated the Co-binding capacity of human serum by adding an excess of Co $\left(2500 \mu \mathrm{g} \mathrm{L}^{-1}\right)$ to serum. Approximately $90 \%$ was distributed in the large $M_{\mathrm{r}}$ fraction, consistent with the high affinity divalent metal binding sites on albumin. They considered the method offered considerable potential for studying Co dose-response relationships and kinetics in Co supplementation studies and went on to validate the method in a study of human volunteers administered a $\mathrm{CoCl}_{2}$ dietary supplement.

5.4.6 Copper. Early diagnosis of Wilson's disease (WD), a genetic disorder of $\mathrm{Cu}$ metabolism, is hampered in new-borns by the fact that immature liver function can replicate the low serum $\mathrm{Cu}$ level symptomatic of the disease. Aramendia et al. ${ }^{92}$ investigated the determination of $\mathrm{Cu}$ isotopes in serum as an alternative diagnostic test. The group looked for the isotopic composition of $\mathrm{Cu}$ in serum samples from WD patients and subjects with normal serum Cu levels. Serum $\mathrm{Cu}$ isotopes were quantitatively determined by MC-ICP-MS after chromatographic separation of $\mathrm{Cu}$ from the protein matrix using a strong anion exchange resin (AG-MP-1). Despite the small number of participants in this pilot study, the researchers were able to use a combination of total $\mathrm{Cu}$ concentration and $\mathrm{Cu}$ isotope composition to correctly classify WD patients, infants and controls and they considered the results to be encouraging as a method for getting early diagnosis of this disease. A second group $^{\mathbf{2 0}}$ investigated the merit of determining $\mathrm{Cu}$ isotope ratios in urine as a potential aid to the diagnosis of the disease. They used a $257 \mathrm{~nm}$ fs LA device coupled to MC-ICP-MS to directly determine $\mathrm{Cu}$ isotopes in dried urine spots. Dried urine samples were prepared by pipetting $300 \mu \mathrm{L}$ of urine onto pre-cut filter paper discs. Nickel was used as an internal standard to correct for instrumental mass discrimination. Using the method, the authors reported significant differences in ${ }^{63} \mathrm{Cu}:{ }^{65} \mathrm{Cu}$ ratios between untreated WD patients, WD patients undergoing treatment and healthy controls, again suggesting merit in this approach for early diagnosis of the disease.

Copper is another element that has been implicated in the pathogenesis of progressive neurodegenerative diseases but for which there is little information regarding the transport and distribution of $\mathrm{Cu}$ in the human brain. Davies et $a .^{83}$ addressed this lack of data by determining the distribution of $\mathrm{Cu}$ and the localisation of $\mathrm{Cu}$ transport proteins in different regions of the human brain. They combined GE, and western blot immunostaining with ICP-MS to determine total $\mathrm{Cu}$ and to characterise specific $\mathrm{Cu}$ transport proteins. Their findings demonstrated a close relationship between the tissue $\mathrm{Cu}$ concentration and $\mathrm{Cu}$ transport protein level. Levels of $\mathrm{Cu}$ in the substantia nigra were twice those in other brain regions whilst levels of the $\mathrm{Cu}$ transport protein ATP7A were elevated in the cerebellum. The authors concluded that $\mathrm{Cu}$ had an important role in these brain regions.

5.4.7 Gallium and Indium. Since the first description of cloud-point extraction as a method for the pre-concentration of selected elements from complex matrices, successive ASU clinical and biological reviews have regularly reported such methods for a wide range of elements. In this review period, Liu and colleagues ${ }^{\mathbf{1 1 1}}$ described the use of cloud-point extraction to extract and pre-concentrate $\mathrm{Ga}$ and In from urine and natural waters for quantitative determination using ICP-AES. Both Ga and In were complexed with 2-(5-bromo-2-pyridylazo)-5-diethylaminophenol and extracted with $1.3 \%$ Triton $\mathrm{X}-100$ at $75{ }^{\circ} \mathrm{C}$ and $\mathrm{pH}$ 7. The reported LODs were $0.72 \mathrm{ng} \mathrm{mL} \mathrm{md}^{-1}$ and $0.29 \mathrm{ng}$ $\mathrm{mL}^{-1}$ for $\mathrm{Ga}$ and In, respectively, and recoveries from spiked samples ranged from $98 \%$ to $102 \%$. The method was evaluated by analysing a range of spiked CRMs.

5.4.8 Gold. Gold-based therapeutic agents are used in the treatment of rheumatoid arthritis and cancer. Magana et al. ${ }^{\mathbf{8 0}}$ investigated the use of EDXRF spectrometry for the quantitative determination of Au in biological tissues as an alternative to more conventional analytical methods used in the clinical laboratory. The authors digested soft tissue samples in $\mathrm{KOH}$ and prepared samples for X-ray analysis by drying $35 \mu \mathrm{L}$ aliquots of tissue digest on a Prolene support in a standard EDXRF cup. They prepared tissue-specific standards in the same way for liver, tumour and mixed tissue types and obtained linear regression values of 0.93 . Gold concentrations (range 5.8-41.3 ppm) were determined in a selection of tumour tissues and found good agreement with results obtained using the more conventional methods of ICP-MS and INAA. It was considered that the method had potential for clinical applications. 
5.4.9 Halides. Recommended clinical chemistry methods for the determination of $\mathrm{Cl}^{-}$in biological fluids are primarily based on electrochemistry (ion-specific electrodes or coulometry). In relation to atomic spectrometric methods, on the other hand, $\mathrm{Cl}$ species are commonly reported as interfering ions which require removal by sample pre-treatment or instrumental correction to allow for quantitative determination of the trace element of interest. It was somewhat refreshing, therefore, to see the group of Pullan et al. ${ }^{\mathbf{1 1 2}}$ used ICP-MS to quantitatively determine $\mathrm{Cl}^{-}$in sweat, a clinical measurement undertaken to support the diagnosis of cystic fibrosis. The authors evaluated the method by analysing the proficiency testing samples for $\mathrm{Cl}^{-}$ in sweat issued by the UK National External Quality Assessment Scheme. The results led the group to introduce the ICP-MS method routinely in their laboratory. It seems to make good economic sense, given the capital costs of such instrumentation, to ensure it is used as much as possible within a busy clinical chemistry laboratory.

Nutritional anthropology studies have routinely used $\mathrm{N}$ isotope ratios to assist in estimating the marine component of diets. However, the elevated ${ }^{15} \mathrm{~N}$ levels, consistent with a history of high seafood consumption, can be influenced by physiological conditions affecting $\mathrm{N}$ balance, e.g., climate and other environmental factors. Dolphin et al. ${ }^{113}$ conducted a pilot study to examine whether $\mathrm{Br}$ concentrations in teeth and bone specimens could complement $\mathrm{N}$ isotope ratio measurements in helping elucidation marine paleodiets. Bromine was determined in archaeological specimens of teeth and bone using SRXRF spectrometry. Blind analysis of the $\mathrm{Br}$ content correctly differentiated samples from individuals who had resided in coastal regions from those derived from inland regions. The authors concluded that Br determination could help clarify the interpretation of $\mathrm{N}$ isotope data.

A number of pharmaceuticals, including analgesics, sedatives and anti-histamines, involve the application of $\mathrm{Br}$ chemistry in their manufacture. Muller et al. ${ }^{35}$ described a method for the determination of $\mathrm{Br}$ and $\mathrm{I}$ in active pharmaceutical ingredients using ICP-MS, following decomposition by microwave-induced combustion and dilution in $50 \mathrm{mmol} \mathrm{\textrm {L } ^ { - 1 }}$ $\left(\mathrm{NH}_{4}\right)_{2} \mathrm{CO}_{3}$. Reported LODs were $0.02 \mu \mathrm{g} \mathrm{g} \mathrm{g}^{-1}$ and $0.001 \mu \mathrm{g} \mathrm{g}^{-1}$ for $\mathrm{Br}$ and I, respectively. The method was validated by analysis of CRMs and agreement with certified values was better than $95 \%$ for both elements. Results obtained with this method were compared with those obtained using IC.

5.4.10 Iron. Given the importance of adequate Fe status in newborns and young infants, it is not surprising that there have been a considerable number of publications on this topic in recent years. Whilst early studies focused on the determination of total $\mathrm{Fe}$ in the biological matrices of interest, advances in metallomics has led to more recent studies focussing on the interaction of Fe with proteins and other biomolecules. Gonzalez-Iglesias et al. ${ }^{\mathbf{1 1 4}}$ administered formula milk enriched with ${ }^{54} \mathrm{Fe}$ and ${ }^{57} \mathrm{Fe}$ to lactating rats in order to study the absorption and bioavailability of the element. Concentrations of $\mathrm{Fe}$ in faeces, urine, serum, erythrocytes, liver and kidney were determined using ICP-MS. The researchers used the mathematical approach of isotope pattern deconvolution to discriminate isotope patterns derived from mixtures of $\mathrm{Fe}$ with natural abundance and ${ }^{57} \mathrm{Fe}$ enriched tracer, which enabled better understand the bioavailability and kinetics of Fe after two weeks of Fe supplementation. The same group ${ }^{\mathbf{1 1 5}}$ carried out speciation studies of $\mathrm{Fe}$ in formula milk and human milk from pre-term and full-term mothers at different stages of lactation. Iron-containing species were separated and quantitatively determined using SEC-ICP-MS. In human milk Fe was principally associated with high $M_{\mathrm{r}}$ protein species, whereas for formula preparations it was primarily associated with the low $M_{\mathrm{r}}$ fraction.

Past work describing the relationship between trace element concentrations in the brain and neurodegenerative disorders such as Alzheimer's disease and Parkinsonism tended to focus on the role of $\mathrm{Al}$ and $\mathrm{Mn}$ as potential contributors to the pathogenesis of such disease states. More recently a potential role for Fe has also been hypothesised. Work presented by Chen et $a .^{55}$ described a novel method for directly determining the dietary uptake of Fe and transfer to the brain in rats fed ${ }^{57} \mathrm{Fe}$ labelled drinking water. The concentration of $\mathrm{Fe}$ in various tissues was determined using NTIMS. The authors noted that only a small fraction of dietary Fe entered the brain but, when compared with the total brain content of $\mathrm{Fe}$, this represented around 9\% of brain $\mathrm{Fe}$, which was consistent with the \% uptake in other organs and tissues. They argued that the results suggest that brain uptake of Fe is much higher than previously thought and that Fe may indeed have a role in the pathogenesis of some neurodegenerative diseases. Iron absorption is strongly influenced by Fe status, however, and the nutritional Fe status of the rats in this study was not defined.

5.4.11 Lead. In the 20-plus ASU reviews that this reviewer has contributed to, $\mathrm{Pb}$ has always been one of the most prominent elements of the review. It is somewhat of a novelty, therefore, to be reporting on only two $\mathrm{Pb}$ studies of interest in this review period. It has been assumed for many years that $\mathrm{Pb}$ isotope ratios do not alter during chemical or biological processes, which has led to $\mathrm{Pb}$ isotope ratio measurements in biological tissues and fluids being used to identify likely sources of exposure. However, recent evidence, reported briefly in last year's review, ${ }^{1}$ has suggested that $\mathrm{Pb}$ isotope ratios in different biological samples are not always identical to the original exposure source. Wu et al. ${ }^{116}$ examined the biological fractionation of $\mathrm{Pb}$ in biological samples from rats acutely exposed to lead acetate via the respiratory route. Lead isotope ratios in blood, urine and faeces were determined using ICP-MS. The researchers observed significant differences in the isotope ratios between the different biological matrices and also a nonlinear relationship between total blood $\mathrm{Pb}$ concentration and $\mathrm{Pb}$ isotope ratios, with a clear threshold concentration for blood $\mathrm{Pb}$ fractionation. They noted that only blood and faeces ${ }^{204} \mathrm{~Pb}:{ }^{206} \mathrm{~Pb}$ ratios matched the ratio in the lead acetate to which the rats were exposed.

A long-held theory that $\mathrm{Pb}$ poisoning in members of the tragic Franklin Arctic expedition of 1845 was due to faulty soldering of tinned provisions was severely weakened by the 
results of work undertaken by Martin et al. ${ }^{78}$ They determined $\mathrm{Pb}$ and $\mathrm{Pb}$ isotope ratios in bone fragments from the remains of expedition members using XRF spectrometry and LA-ICP-MS. The XRF spectrometric data revealed widespread distribution of $\mathrm{Pb}$ in the bone fragments, whilst the isotope ratios determined in bone regions with different turnover rates were not significantly different. The authors concluded that these results were inconsistent with the faulty lead solder hypothesis.

5.4.12 Manganese. The health risks associated with occupational exposure to $\mathrm{Mn}$ are well recognised. Excessive exposure can lead to accumulation in the brain and the development of neurodegenerative damage similar to Parkinsonism. Michalke and colleagues ${ }^{87}$ investigated the chemical species responsible for active transport of Mn across the neural barrier. They used SEC and CZE combined with ICP-DRC-MS to characterise Mn species in paired serum and CSF samples. Additional verification of Mn species was obtained using SEC combined with ESI-FT-

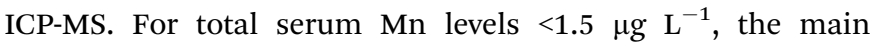
contributory species were Mn-albumin and Mn-transferrin. Total Mn in CSF was only half the total serum value and Mn-transferrin represented only $10 \%$ of the serum value. Increasing $\mathrm{Mn}$ concentrations above $1.6 \mu \mathrm{g} \mathrm{\textrm {L } ^ { - 1 }}$ led to an increase in serum Mn-citrate and this species was observed to be the main influencing factor on total $\mathrm{Mn}$ and Mn-citrate in CSF. They concluded that elevated Mn-citrate could be a valuable biomarker of increased risk of neurodegenerative disorders arising from occupational exposure.

Fujimura et al. ${ }^{117}$ used ICP-MS to investigate the inter-relationship between $\mathrm{Mn}$ and $\mathrm{Zn}$ in rats administered high concentrations of $\mathrm{Zn}$ in their diet. They reported that hepatic concentrations of $\mathrm{Mn}$ decreased in response to increasing $\mathrm{Zn}$ levels which was explained in part by reduced expression of the hepatic Mn transport protein Zip8.

5.4.13 Mercury. Speciation of $\mathrm{Hg}$ in biological samples is still a topic generating a lot of publications. Nevado and colleagues ${ }^{25}$ made a very interesting observation that, in contrast to information on $\mathrm{Hg}$ speciation in tissues from marine species, there was negligible data on $\mathrm{Hg}$ species in tissues from terrestrial animals. They considered the analysis to be challenging due to the lack of commercially available CRMs and the fact that expected concentrations would be low. Nevertheless, they presented a method for the quantitative determination of $\mathrm{Hg}$ in such matrices using headspace-SPME-GC-pyrolysis AFS. Mercury species were extracted from tissues using closed-vessel microwave digestion with alkali and ethylated for headspaceSPME with a $100 \mu \mathrm{m}$ polydimethylsiloxane-coated fibre. Reported LODs for liver tissue were; $31.1 \mathrm{ng} \mathrm{g}^{-1}$ and $52.5 \mathrm{ng} \mathrm{g}^{-1}$ for $\mathrm{MeHg}$ and inorganic $\mathrm{Hg}$, respectively, whilst for kidney they were: $35.3 \mathrm{ng} \mathrm{g}^{-1}$ and $58.1 \mathrm{ng} \mathrm{g}^{-1}$, respectively. The authors validated the method by analysing bovine liver and pig kidney CRMs and used the method to study $\mathrm{Hg}$ species in tissues of deer and wild boar from a $\mathrm{Hg}$ mining region in Spain. Hayashi et $a{ }^{26}{ }^{26}$ reported favourable results for the quantitative determination of $\mathrm{Hg}$ species in seafood CRMs using HPLC coupled with UV irradiation and CV-AAS. They reported effective extraction of $\mathrm{Hg}$ species from the matrix using a 2-mercaptoethanol solution. They analysed a range of real seafood samples using this method and obtained good agreement with values obtained using HG-AAS. de Souza et al. ${ }^{89}$ described a fast and simple method for the determination of $\mathrm{Hg}$ species in serum and plasma. The method combined HPLC with HG-ICP-MS. As with the method described by Hayashi et al. ${ }^{26} \mathrm{Hg}$ species were extracted from the matrix using a 2-mercaptoethanol solution, this time combined with $\mathrm{L}$-cysteine and $\mathrm{HCl}$, and were separated on a $\mathrm{C}_{8} \mathrm{RP}$ column with a mobile phase containing methanol, 2-mercaptoethanol and formic acid. Reported LODs were $12 \mathrm{ng} \mathrm{L}^{-1}, 5 \mathrm{ng} \mathrm{L}{ }^{-1}$, and $4 \mathrm{ng} \mathrm{\textrm {L } ^ { - 1 }}$ for inorganic $\mathrm{Hg}$, EtHg and $\mathrm{MeHg}$, respectively. The method was validated by analysing a bovine blood CRM and samples from the Canadian Quality Assurance Scheme. The authors used the method to study $\mathrm{Hg}$ speciation in plasma samples collected from riverside populations consuming a high proportion of fish in their diet.

Zhang et al. $^{75}$ reported a non chromatographic method for the determination of $\mathrm{iHg}$ and $\mathrm{MeHg}$ in biological matrices using electrolytic $V G$ coupled with AFS. They reported that both $\mathrm{Hg}$ species could be efficiently vaporised after adsorption onto a L-cysteine coated graphite cathode. At low (0.2 A) currents only iHg was vaporised, whilst at a higher current (2 A) both iHg and $\mathrm{MeHg}$ were vaporised, thus by carefully controlling the current to the cathode the authors could differentially determine both species. The LODs in aqueous solutions were $0.098 \mu \mathrm{g} \mathrm{L}^{-1}$ for inorganic $\mathrm{Hg}$ and $0.073 \mu \mathrm{g} \mathrm{L}^{-1}$ for $\mathrm{MeHg}$. The method was validated by analysing marine CRMs.

Finally, a Czech group ${ }^{76}$ presented findings from a comprehensive study to assess the merit of urinary calculi as a biomarker of $\mathrm{Hg}$ exposure. They used thermo-oxidation CV-AAS to quantitatively determine total $\mathrm{Hg}$ concentrations in 489 calculi samples collected from across the entire Czech Republic. They observed a strong correlation between the $\mathrm{Hg}$ concentration and Se concentration in the calculi and reported a mean value of $0.37 \mathrm{mg} \mathrm{kg}^{-1}$ for stones from individuals in the age range of 41-50 years, which fell to $0.06 \mathrm{mg} \mathrm{kg}^{-1}$ in the 'over 80s'. They considered urinary calculi could provide valuable complimentary data to other biomarkers on $\mathrm{Hg}$ exposure. However, the opinion of this reviewer is that use of this sample type for exposure monitoring is not realistic.

5.4.14 Nickel. The hypothesis that the prevalence of $\mathrm{Ni}$ sensitisation in children is increased by environmental exposure and exacerbated by nickel ingestion led Wilhelm et al. ${ }^{118}$ to examine factors influencing urinary excretion of $\mathrm{Ni}$ as part of the German Environmental Survey. Nickel was determined using ETAAS with Zeeman background correction following solvent extraction of the element from the urine matrix. Levels of $\mathrm{Ni}$ ranged from $<0.5$ to $15 \mu \mathrm{g} \mathrm{L}^{-1}$ and multivariate analysis identified a number of significant predictors of $\mathrm{Ni}$ excretion including age, gender, creatinine concentration and consumption of nuts, cereals and chocolate. The authors noted no influence on $\mathrm{Ni}$ excretion from drinking water or passive smoking. A separate German group ${ }^{\mathbf{1 1 9}}$ also investigated the influence of dietary factors on urinary $\mathrm{Ni}$ excretion. They studied a group of female patients with or without Ni contact dermatitis. Urinary Ni was quantitatively determined using AAS. The researchers reported a $95^{\text {th }}$ percentile value of $3.77 \mu \mathrm{g} \mathrm{L}^{-1}$ for women under the age of 30 and a value of $3.98 \mu \mathrm{g} \mathrm{L}^{-1}$ for 
women over 30 . Both $95^{\text {th }}$ percentile values were above a reference value of $3 \mu \mathrm{g} \mathrm{L}^{-1}$. They also used multivariate analysis to establish that urinary Ni excretion was significantly influenced by age, ingestion of dietary supplements and nickel-rich foods. They also noted that consumption of stagnant tap water (presumably first drawn tap water) was associated with an increase in $\mathrm{Ni}$ excretion a finding that appears to be at odds with that of Wilhelm and colleagues. ${ }^{118}$ It is pertinent to note the considerable difference in the upper values of $\mathrm{Ni}$ between the two studies $\left(3.8 \mu \mathrm{g} \mathrm{L}^{-1}\right.$ vs $\left.15 \mu \mathrm{g} \mathrm{L}^{-1}\right)$.

5.4.15 Platinum. With continuing use of Pt-based drugs in cancer therapies, studies are being undertaken to identify the important Pt-protein complexes generated by these treatments. Moreno-Gordoliza et al. ${ }^{\mathbf{8 1}}$ used both 2D gel electrophoresis, combined with LA-ICP-SF-MS, and HPLC-ESI-linear ion trap-FTMS/MS to characterise Pt containing peptides in serum samples collected from a rat administered cisplatin. They observed that direct LA of glycerol-treated gels gave better sensitivity and more reliable Pt signals than more conventional analysis of blotted membranes. Ablating the gels also simplified things by avoiding the need to run gels in parallel for separate Pt detection and protein identification. The researchers characterised Pt bound to $\alpha_{2}$-macroglobulin, transferrin, albumin and haemoglobin. They also used the technique to establish a $2 \mathrm{D}$ metalloprotein map for Pt complexes in epithelial cells of the renal proximal tubule. A number of Pt-protein complexes were identified, which they hypothesised may have a role in the drug induced nephrotoxicity that can be caused by cisplatin treatment. An Austrian group ${ }^{\mathbf{1 2 0}}$ combined LC with ICP-MS to quantitatively determine intact cisplatin, free Pt and Pt-protein complexes in a cell model in order to better elucidate the intracellular kinetics of the drug. Pseudo first order kinetics for intracellular accumulation was observed which was hypothesised to be due to a large excess of potential Pt-binding components, a significant fraction of which were high $M_{\mathrm{r}}$ biomolecules. Throughout the experimental timeframe, intact cisplatin was the predominant species in the low $M_{\mathrm{r}}$ fraction of the cytosol. The study results led the authors to propose that passive diffusion was the principal cellular uptake mechanism. Drug efflux was observed to be biphasic. Intact cisplatin was rapidly removed whereas $30 \%$ of the $\mathrm{Pt}$-protein adduct fraction still remained in the cytosol after $24 \mathrm{~h}$ of incubation.

Wu et al. $^{49}$ described a novel method for the determination of Pt in human plasma using ICP-MS with a microfluidic chip nano-FI system. The microchip design could handle sample volumes below $200 \mu \mathrm{L}$ and with this sample volume and a

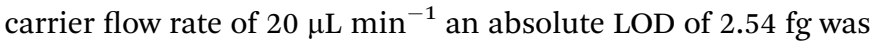
reported, a 3244 factor improvement over conventional sample introduction according to the authors.

5.4.16 Rare earth elements. There is a growing use of REEs as non-toxic alternatives to heavy metals in the manufacture of high technology products. However, these elements are not to be considered entirely innocuous. Kitamura et al. ${ }^{\mathbf{1 2 1}}$ reported the results of studies to assess the suitability of urinary REE determination for biological monitoring of occupational and environmental exposure to these elements. The researchers administered chlorides of $\mathrm{Eu}, \mathrm{Sc}$ and $\mathrm{Y}$, either orally or by intraperitoneal injection to rats and determined concentrations of 16 elements in urine samples using ICP-AES. They recorded that urinary excretion of REEs was less than $2 \%$ of the administered dose. Nevertheless, they considered the method to be sufficiently sensitive to be considered a suitable bio-monitoring tool for assessment of exposure to REEs.

5.4.17 Selenium. Interest in Se speciation continues and, with the large number of methods that have been published for Se speciation analysis in recent years, it is becoming difficult for the clinical chemist to decide which are the most reliable. A Chinese group ${ }^{22}$ described a novel method for the determination of Se species in small samples of Se-enriched yeast cells using a similar microfluidic chip technology to that described in the section on Pt. They developed an integrated chip for reaction, mixing and extraction of selected seleno-amino acid and selenoprotein species. The species were extracted by adsorption onto sulfonated polystyrene-coated $\mathrm{Fe}_{3} \mathrm{O}_{4}$ nanoparticles. The authors systematically investigated factors affecting the extraction of Se species and, with optimised conditions, they obtained LODs ranging from $0.057 \mu \mathrm{g} \mathrm{L}^{-1}$ to $0.149 \mu \mathrm{g} \mathrm{L}^{-1}$ for five Se species. They considered the low sample and reagent consumption was particularly well suited to the analysis of very small sample sizes (e.g., approximately 800 yeast cells). The average quantity of selenocysteine and selenomethionine in a single yeast cell was estimated to be in the order of sub-picograms.

Clinical chemistry methods for determining enzymes in cells and tissues are usually based on immunochemistry or the measurement of enzyme activity. The work of the research group from Oviedo, led by Sanz-Medel, is regularly reported in this review. They have now proposed a method ${ }^{122}$ for the absolute quantification of GPx in human erythrocytes based on the measurement of Se. After haemoglobin precipitation, the blood sample was further fractionated by SEC and Se quantitatively determined using ICP-MS. Purity of the GPx fraction was assessed by capillary RP-HPLC-ICP-MS and ESI-MS following tryptic digestion of the protein fraction. The method was compared with results obtained using a conventional spectrophotometric method for GPx activity and excellent correlation was reported. By interpolation of this curve, the researchers concluded that they could simultaneously obtain the absolute concentration of GPx as well as the enzyme activity from an ICPMS determination of Se. A comprehensive study of Se species in paired serum and CSF samples was described by Solovyev et al. ${ }^{\mathbf{8 6}}$ They determined Se species in paired samples from 24 neurologically healthy individuals using strong anion exchange HPLC coupled with ICP-DRC-MS. The LODs ranged from 0.026 to $0.031 \mu \mathrm{g} \mathrm{L}^{-1}$. Reported median values were; for selenoprotein $\mathrm{P}$, $5.19 \mu \mathrm{g} \mathrm{L}^{-1}$ in serum and $0.47 \mu \mathrm{g} \mathrm{L}^{-1}$ in CSF, for SeMet, $0.23 \mu \mathrm{g}$

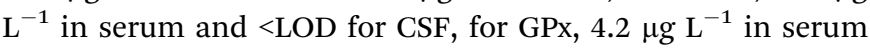
and $0.7 \mu \mathrm{g} \mathrm{L}^{-1}$ in CSF. From the serum to CSF Se ratio values determined for the oxidative Se enzymes GPx and thioredoxin reductase the authors hypothesised that there was either facilitated transport across the neural barrier or protein synthesis within the brain for these two species.

The complication of determining ultra-trace levels of Se in biological matrices by ICP-MS, due to spectral interferences and 
the high first ionisation energy of Se is well recognised. Guo et al. $^{36}$ tackled these analytical challenges by developing a method using mixed plasma gas ICP-DRC-MS. The use of $\mathrm{CH}_{4}$ as reaction gas eliminated the spectral interference from ${ }^{40} \mathrm{Ar}_{2}{ }^{+}$, whilst the mixed $\mathrm{CH}_{4}-\mathrm{Ar}$ plasma gas reduced minor interferences from ${ }^{63} \mathrm{Cu}^{16} \mathrm{OH}^{+},{ }^{64} \mathrm{Zn}^{16} \mathrm{O}^{+}$and ${ }^{64} \mathrm{Cu}^{16} \mathrm{O}^{+}$hydroxide and oxide ions by more than $50 \%$. Furthermore presence of $\mathrm{C}$ in the plasma gas also improved Se ionisation to give a three-fold improvement in sensitivity. The authors thoroughly validated the method and obtained good agreement with certified values for 50 biological CRMs.

5.4.18 Silver. The novel physicochemical characteristics of elemental nanoparticles has led to their use in an ever-growing number of technological and medical applications, a number of which have been reported in recent ASU reviews. There still appears, however, to be limited detailed understanding of their toxicity to biological systems. Two papers in this review period provided more information on the biological fate of $\mathrm{Ag}$ nanoparticles. Draude et al. ${ }^{102}$ investigated the effect of Ag nanoparticles on human macrophages. The authors used TOF-SIMS to characterise fragments from macrophage cell membranes and laser-SNMS to measure the three-dimensional distribution of Ag within the cells. They noted the accumulation of discrete nanoparticles immediately below the cell membrane as well as agglomeration of particles within the cell cytoplasm. EspinosaCristobal et al. ${ }^{50}$ studied the distribution and localised accumulation of Ag in Wistar rats following oral administration of suspensions of $14 \mathrm{~nm}$ or $36 \mathrm{~nm} \mathrm{Ag}$ nanoparticles. Concentrations of $\mathrm{Ag}$ were quantitatively determined in selected organs using ICP-MS. Toxicity of the nanoparticles was assessed by a battery of clinical chemistry, haematological and histopathology tests. Highest concentrations of Ag were determined in the small intestine, kidney, liver and brain. Clinical chemistry and haematology results showed changes in blood urea nitrogen, total protein and mean corpuscular haemoglobin but these were not dependent on $\mathrm{Ag}$ concentration or nanoparticle size. A Canadian group ${ }^{123}$ described a simple screening method for the differential determination of dissolved $\mathrm{Ag}$ and nanoparticle Ag in biological matrices using ETAAS with Zeemaneffect background correction. The researchers observed that the atomisation temperature for $\mathrm{Ag}$ increased with increasing particle size and this phenomenon could be used to discriminate dissolved $\mathrm{Ag}$ from nanoparticles of 20,60 and $80 \mathrm{~nm}$ diameter. They used the method to determine dissolved $\mathrm{Ag}$ and nanoparticle $\mathrm{Ag}$ in liver of rainbow trout exposed to these $\mathrm{Ag}$ species.

The efficacy of $\mathrm{Ag}$ as a bacteriocide has been recognised for centuries. With the recent development of $\mathrm{Ag}$ nanoparticle technology, there has been renewed interest in this characteristic, with the production of silver-containing dressings to control infection in burns cases being an example of this. However, there appears to have been little research examining the chemical composition and $\mathrm{Ag}$ release kinetics of the various types of commercially available dressings. An Italian group ${ }^{124}$ used SEM, to characterise the morphology, and ICP-MS to quantitatively determine $\mathrm{Ag}$ concentrations and $\mathrm{Ag}$ release kinetics of four such burns dressings. Silver concentrations in

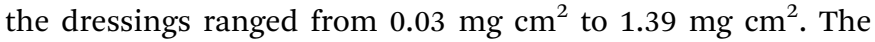
release kinetics were determined in three media, ultrapure water, saline and human serum substitute. Highest rates of Ag release (up to $4099 \mu \mathrm{g} \mathrm{h}^{-1} \mathrm{~cm}^{-2}$ ) were observed with human serum substitute but they considered the $\mathrm{Cl}^{-}$concentration of the saline solution inhibited the release of $\mathrm{Ag}$ from the dressing.

Moradkhani et al. ${ }^{125}$ described a sensitive method for the quantitative determination of $\mathrm{Ag}$ in biological matrices using ETAAS after electro-deposition of Ag on a palladium-modified graphite tube. The authors investigated optimal parameters for electro-deposition including deposition potential, deposition time and solution $\mathrm{pH}$. With optimised conditions the LOD and LOQ were $2.8 \mathrm{ng} \mathrm{L}^{-1}$ and $9.4 \mathrm{ng} \mathrm{L}^{-1}$, respectively. The method was used to determine $\mathrm{Ag}$ in blood and urine following microwave-assisted digestion of the samples with $\mathrm{HClO}_{4}$.

5.4.19 Strontium. Whereas strontium ranelate is an approved medication for osteoporosis in the UK and Europe, it is not licensed in the USA or Canada. On the other hand, strontium citrate is readily available as an over the counter nutritional supplement. Wohl et al. ${ }^{77}$ investigated the accumulation of $\mathrm{Sr}$ in bones of female rats administered these two $\mathrm{Sr}$ compounds daily over an 8 week period. Bone Sr was measured at the outset of the study and at the conclusion of the 8 week period using an in vivo XRF spectrometric technique previously used for human studies. The measurements were validated against ex vivo measurements of bone Sr using ICP-MS. Bone $\mathrm{Sr}$ was highest in rats administered strontium citrate but this was found to be due to the higher dosing of rats administered the citrate compound as identified by post hoc analysis of the $\mathrm{Sr}$ compounds using EDS microanalysis. ANOVA analysis of the data revealed no significant difference in bone $\mathrm{Sr}$ levels between the two groups of rats given $\mathrm{Sr}$ supplementation but these levels were much higher than in the control group. Perhaps the key lesson to be taken from this paper is the importance of fully characterising any compounds used for nutritional supplementation studies rather than relying on data provided by the manufacturer.

5.4.20 Tin. Despite a ban on organotin compounds in antifouling paints and systems being ratified in 2008 by 66 States, representing $82 \%$ of the world's merchant fleets, there continues to be concerns over the environmental impact of these compounds in marine environments. Sunday et al. ${ }^{15}$ presented a detailed review of the chemical speciation of organotin compounds in environmental and biological matrices. Zachariadis $e t$ al. ${ }^{21}$ investigated the effect of storage conditions on the stability of tributyltin (TBT) species in human urine. Spiked urine and buffer samples were stored at $4{ }^{\circ} \mathrm{C}$ and $-20^{\circ} \mathrm{C}$ for up to one month. Tributyltin was derivatised in situ using $\mathrm{NaB}\left(\mathrm{C}_{2} \mathrm{H}_{5}\right)_{4}$ and quantitatively determined using headspaceSPME-GC-MS. The researchers observed that TBT was stable at both temperatures for a maximum of 2 days storage. Beyond this time, concentrations in samples stored at $4{ }^{\circ} \mathrm{C}$ varied more than those at $-20^{\circ} \mathrm{C}$. They also noted that freeze-thaw cycles also had an adverse effect on TBT stability and that these should be kept to a minimum.

5.4.21 Titanium. Omlor et al. ${ }^{46}$ monitored serum Ti levels in a large cohort of patients who had undergone total hip 
arthroplasty with a novel modular stem system. Serum Ti concentrations were determined using HR-ICP-MS. From their findings, they concluded that there was no significant increase in serum Ti compared with individuals fitted with non-modular implants. The authors considered that further long-term studies were needed to evaluate the value of serum Ti determination as a diagnostic tool to identify failure of Ti-based implants. However, in a few non-published studies, increased concentrations have been seen in samples from patients where the implants had failed.

Studies to simplify home-based collection protocols for patients requiring regular monitoring of trace element status have been reported frequently in this review series. Many of these employed collection of biological fluids onto filter paper for subsequent quantitative determination of the element of concern. The problems, including contamination risk, associated with such procedures have been emphasised by members of this review team who have experience of such methods. Nevertheless, Rello et al. ${ }^{19}$ used such a method to collect spot urine samples in order to monitor Mo and Ti levels in patients with metal prostheses. They re-iterated two problems with this approach; the fact that filter paper acts as a chromatographic support and therefore generates a differential distribution of the element of interest and that urine spreads over a large surface area thereby reducing analytical sensitivity. To minimise these problems the authors used pre-cut filter pieces of $19 \mathrm{~mm} \times 17 \mathrm{~mm}$ onto which $500 \mu \mathrm{L}$ of urine was deposited. Total Mo and Ti were determined using ETAAS. Calibration was performed with matrix-matched urine standards subjected to the same procedure as samples. Reported LODs were $1.5 \mu \mathrm{g} \mathrm{L}^{-1}$ and $6.5 \mu \mathrm{g} \mathrm{L}^{-1}$ for Mo and Ti, respectively. The authors considered the method offered potential for monitoring patients with metal prostheses in order to detect early evidence of prosthesis failure.

5.4.22 Uranium. Uranium is widely distributed in the environment with a reported abundance similar to $\mathrm{Sn}$ and Mo. Its presence in food and drinking water means that individuals can ingest a few $\mu \mathrm{g}$ of the element daily. Previous studies have shown that ingested $U$ is primarily deposited in bone. Lariviere et $a l .{ }^{\mathbf{1 2 6}}$ examined the merit of determining bone $U$ as an indicator of chronic environmental exposure to $\mathrm{U}$ from drinkingwater. A total of 71 archived vertebrae samples from residents of 7 Canadian cities were digested and $U$ concentrations determined using ICP-MS. The vertebrae U levels showed very good correlation $\left(r^{2}=0.97\right)$ with $\mathrm{U}$ concentrations in the municipal drinking water supply, obtained from historical 'Health Canada' studies. The authors compared the experimental data with data generated by a mathematical model for systemic uptake of $\mathrm{U}$, developed by the International Commission on Radiological Protection, using two gastrointestinal tract absorption factors $(f=0.009$ and 0.03). They concluded that neither of these absorption factors could adequately estimate the observed experimental values. The lower value best modelled intake from food alone whilst the higher value only gave good estimates of

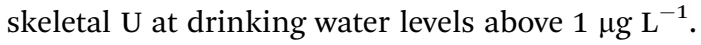

5.4.23 Zinc. Urgast et al. ${ }^{127}$ investigated tissue distribution of $\mathrm{Zn}$ at the 'microscale' level using LA-MC-ICP-MS. Following injection of stable ${ }^{67} \mathrm{Zn}$ and ${ }^{70} \mathrm{Zn}$ isotopes into mice, they determined $\mathrm{Zn}$ isotope ratio distribution in ultra-thin liver and brain sections. They observed different $\mathrm{Zn}$ isotope ratios in different brain regions. Cortex and hypothalamus had high levels of tracer shortly after injection when compared with hippocampus and amygdala which led the authors to hypothesise that these brain regions differ in their $\mathrm{Zn}$ metabolism kinetics.

\section{Applications: Drugs and pharmaceuticals, traditional medicines and supplements}

Rigo et al. ${ }^{\mathbf{1 2 4}}$ sought to bring some understanding to the release of $\mathrm{Ag}$ from silver-based dressings applied to burns to prevent infection. Release kinetics of Ag from dressings into sterile pure water, normal saline and a serum substitute, were determined. Serum was the most effective extraction medium at $4099 \mu \mathrm{g} \mathrm{h}^{-1}$ $\mathrm{cm}^{-2}$ ) and mean bacterial growth inhibitory concentrations of $\mathrm{Ag}$ were achieved with serum and pure water, whereas a high $\mathrm{Cl}^{-}$environment inactivated the dressings. Anyone who has measured $\mathrm{Ag}$ in serum samples from patients being treated with silver dressings or ointments will have realised just how readily transfer and absorption takes place.

Focused ultrasound-assisted extraction used in a procedure to measure concentrations of $\mathrm{Cr}$ and $\mathrm{Mn}$ in ciprofloxacin, cephalexin, azithromycin, amiodipine and methionine was described in Section $3.2,{ }^{34}$ as were the use of microwave combustion $^{35}$ and a method to avoid loss of volatile Os species ${ }^{33}$ during the analyses of various pharmaceutical preparations. These applications follow from the requirement (currently postponed) in the USA to test pharmaceuticals for possible contaminants.

Hedegaard et al. ${ }^{\mathbf{1 2 8}}$ analysed herbal dietary supplements and reported the concentrations of total As and iAs, as determined by ICP-MS. Concentrations of total As were $0.58-5.0 \mathrm{mg} \mathrm{kg} \mathrm{kg}^{-1}$ while iAs was at $0.03-3.2 \mathrm{mg} \mathrm{\textrm {kg } ^ { - 1 }}$. The iAs:total As ratios were from $5 \%$ to $100 \%$. It was calculated that use of the recommended amounts would provide up to $13 \mu \mathrm{g}$ day $^{-1}$ or $62.4 \%$ of the European Food Safety Authority benchmark dose lower confidence limit value. Twelve elements were determined in Korean Panax Ginseng (Panax ginseng), Golden Seal (Hydrastis canadensis), Ginger Root (Zingiber officinale), St. John's Wort (Hypericum perforatum), Green Tea (Camellia sinensis) and Valerian Root (Valeriana officinalis) by LA-ICP-MS of pelleted powdered material and by ICP-MS of acid digested solutions. ${ }^{129}$ Ablation was carried out with line scans at a scan rate of $30 \mu \mathrm{m}$ $\min ^{-1}$, at a frequency of $20 \mathrm{~Hz}$ and a spot size of $100 \mu \mathrm{m}$. For the analysis, ${ }^{13} \mathrm{C}$ was used as the internal standard and a leaf CRM was similarly prepared and analysed for the purpose of calibration. The results were similar to those given by ICP-MS with pneumatic nebulisation.

While ICP-MS might be the usual analytical technique to determine trace elements in these samples, various other approaches are sometimes employed. A method to measure $\mathrm{Pb}$ concentrations in medicinal plants, using slurry sampling and 
HR-CS-ETAAS, was reported by Rego et al. ${ }^{64}$ Various modifiers were tested and the best performance was given with $\mathrm{Pd}\left(\mathrm{NO}_{3}\right)_{2}$. Lead contents of various medicinal plants samples were in the range $0.30-1.94 \mu \mathrm{g} \mathrm{g}^{-1}$. The LOQ was $0.024 \mu \mathrm{g} \mathrm{g}^{-1}$ with an RSD of $10 \%$ at a concentration of $0.88 \mu \mathrm{g} \mathrm{g}^{-1}$. No review of dietary supplements would be complete without mention of Se. Tyburska and Jankowski ${ }^{70}$ eschewed conventional analytical techniques and developed a somewhat complicated procedure which they referred to as HG head space SPME-MIP-OES. This involved generation of $\mathrm{H}_{2} \mathrm{Se}$, headspace SPE followed by thermal desorption into a MIP source for measurement of the Se by OES. An acceptable result was obtained for a wheat gluten CRM.

\section{Applications: Foods and beverages}

\subsection{Progress for individual elements}

7.1.1 Arsenic. General papers on advances in As were few this year although overall there was a high number of applications in the food industry, as detailed in the sections below. A non-chromatographic system was developed for HG-AFS determination of DMA, iAs and total As in water samples. ${ }^{72}$ An automated multi-syringe FI manifold enabled options of an inline UV photo-oxidation of DMA, a direct analysis of iAs on an extracted sample or a determination of total As following digestion. The LODs achieved were 0.09 and $0.47 \mu \mathrm{g} \mathrm{L}^{-1}$ for DMA and iAs, respectively, while the repeatability was quoted as 2.4 and $1.8 \%$. Adding an on-line HG step to HPLC-ICP-MS improved the selectivity and increased the sensitivity for the determination of iAs in seafood. ${ }^{\mathbf{1 3 0}}$ Post-column addition of a reducing agent $\left(\mathrm{NaBH}_{4}\right)$ generated $\mathrm{AsH}_{3}$ in situ from iAs but not from organic As species. The resulting LOD and LOQ were 0.0004 and $0.0014 \mathrm{mg} \mathrm{kg}^{-1}$.

7.1.2 Mercury. The determination of $\mathrm{Hg}$ at concentrations close to the $L O D$ in ICP-MS with conventional sample introduction is hampered not only by memory effects but also by analyte loss. This situation was improved by Drennan-Harris et al. ${ }^{\mathbf{1 3 1}}$ who added L-cysteine (1\%) to samples, standards and wash solutions to keep $\mathrm{Hg}$ in solution; they also injected $\mathrm{Au}\left(1 \mu \mathrm{g} \mathrm{L}^{-1}\right)$ on-line as internal standard for improved signal precision and accuracy. Wash-out times were dramatically reduced (from 113 min to $13.2 \mathrm{~min}$ ) and loss of analyte during microwave digestion was minimised. The free sulfhydryl groups of cysteine residues are known for their binding ability to $\mathrm{MeHg}$; however, knowledge of discrete binding in animal muscle is scarce. Kutscher et $a l .{ }^{\mathbf{1 3 2}}$ therefore employed metallomic techniques, including LC-ICP-MS and ESI-MS to investigate. Due to the stability of the $\mathrm{Hg}-\mathrm{S}$ bond, the $\mathrm{Hg}$-bio-conjugates were extracted into tris(hydroxymethyl)aminomethane and SDS followed by separation using SEC and SDS-PAGE. As major binding occurs with high $M_{\mathrm{r}}$ proteins ( $>20 \mathrm{kDa})$, the skeletal muscle myosin heavy chain was postulated as a potential target protein for $\mathrm{MeHg}$. A method for the concentration and determination of $\mathrm{Hg}^{\mathrm{II}}$ in drinking water by solid-phase XRF spectrometry was developed by Aranda et $a{ }^{133}$ Sample preparation involved the analyte adsorption onto activated carbon containing the ionic liquid Aliquat 336 ( $N$-methyl, $N, N, N$-trioctylammonium chloride). An enrichment factor of 1700 and a $\mu \mathrm{g} \mathrm{L}^{-1}$ working concentration zone were achieved without the added complications of elution or use of VG technology. A non-chromatographic technique for $\mathrm{Hg}$ speciation devised by Zhang et al. ${ }^{75}$ used electrolytic reduction on an L-cysteine-modified graphite cathode before VG-AFS. Conversion of $\mathrm{Hg}^{\mathrm{II}}$ to $\mathrm{Hg}^{0}$ occurs at low current (0.2 A) whereas a higher current (2.2 A) was required for conversion of $\mathrm{MeHg}$ leading to LODs of 0.098 and $0.073 \mu \mathrm{g} \mathrm{L}^{-1}$ and precisions of 3.2 and $4.7 \% \mathrm{RSD}$, respectively. Determination of $\mathrm{Hg}$ in water samples by a novel combination of flow-through electrochemical VG with a microstrip MIP-AES was described by Cerveny et $a l .{ }^{69}$ A laboratory-constructed thin-layer flow-through hydrogen remover was used, resulting in a LOD of $1.1 \mathrm{ng} \mathrm{mL}$

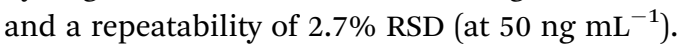

7.1.3 Selenium. The Se metabolome of Se-enriched yeast was comprehensively described following a bimodal separation process prior to HPLC-ICP-MS or HPLC-ESI-MS. ${ }^{82}$ Separation was carried out on two parallel columns with a porous graphite carbon stationary phase and RP and HILIC functionality. Of the 64 selenometabolites detected, 21 were previously unreported and nine were identified by $\mathrm{MS}^{n}$. The constituents of the metabolome were principally 14 selenoethers, 28 di- and tripeptide conjugates of SeCys, and some selenols and selenoxides. Intracellular Se speciation of enriched yeast cells was carried out using a microfluidic magnetic SPE combined with HPLC-ICP-MS. ${ }^{22}$ Sulfonated polystyrene-coated magnetic nanoparticles were prepared for the adsorption of selenoamino acids and selenopeptides. An on-chip format was tested and found to have approximately half the sensitivity but demonstrated the advantage of requiring low sample consumption. From the analysis of $c a .800$ cells the authors showed that one cell had average concentrations of SeCys ${ }_{2}$ and SeMet in the order of sub picograms. An atomically imprinted polymer synthesised from $\mathrm{SeO}_{2}$, 4-vinylpyridine and vinylimidazole was used in a minicolumn $(5.4 \mathrm{~cm} \times 2.1 \mathrm{~cm})$ for the preconcentration and determination of Se using FI-HG-FAAS. ${ }^{23}$ An LOD of $53 \mathrm{ng} \mathrm{\textrm {L } ^ { - 1 }}$ was obtained which the authors claim to be the best currently reported. Interferents such as $\mathrm{Cu}^{2+}$ and $\mathrm{Cr}^{3+}$ were noted and therefore analysis by standard additions was recommended in their presence. A cheap and simple FAAS method for determining Se in a variety of food matrices was proposed by Ulusoy et al. ${ }^{\mathbf{1 3 4}}$ Sample preparation used CPE combined with $\mathrm{Se}^{\mathrm{IV}}$ complexation by the dye Pyronine B (3,6-bis(diethylamino)xanthylium chloride-ferric chloride). Samples were first prepared by microwave-assisted digestion and then $\mathrm{Se}^{\mathrm{VI}}$ was reduced to $\mathrm{Se}^{\mathrm{IV}}$ with $\mathrm{HCl}(5 \mathrm{M})$ and further microwave heating. The sample solution was then mixed with SDS, PONPE-7.5 (polyoxyethylene(7.5) nonylphenyl ether) and the Pyronine B. The LOD was $3.81 \mu \mathrm{g} \mathrm{Se} \mathrm{IV}^{-1}$, and the precision was $2.45 \%$ RSD. The same authors also proposed a similar CPE technique for the determination of $\mathrm{Pb}$ and $\mathrm{Sn}$ but used Acridine Orange and Triton $\mathrm{X}-100 .{ }^{27}$ Determination of Se at $\mathrm{ng} \mathrm{g}^{-1}$ levels by ICPMS is hampered by a high first ionisation energy, serious isobaric interferences on the most abundant isotope, ${ }^{80} \mathrm{Se}$, and low sensitivity. Use of a mixed $\mathrm{CH}_{4}-\mathrm{Ar}$ plasma gas reduced interferences from several minor oxides and hydroxides by $50 \%$ and $\mathrm{CH}_{4}$ in the DRC removed interference from ${ }^{40} \mathrm{Ar}^{2+} \cdot{ }^{36}$ 
Interference from ${ }^{79} \mathrm{BrH}^{+}$required $\mathrm{Br}$ to be removed by evaporation from the digest prior to determination. Sensitivity was improved three-fold due to the carbon-enhancement effect of a $\mathrm{CH}_{4}-\mathrm{Ar}$ gas mixture.

7.1.4 Other elements. Indirect assay of the halogens is one possible approach for measurement by non-MS techniques and a method for the determination of I at low levels was proposed by $\mathrm{Lu}$ et al. ${ }^{71} \mathrm{~A}$ stable complex, $\mathrm{H}_{2} \mathrm{HgI}_{4}$, formed with the $\mathrm{Hg}^{2+}$ in an acidic medium $\left(\mathrm{HNO}_{3}\right)$ and was extracted into IBMK in which it remained for the reduction step, with $\mathrm{KBH}_{4}$. A precision of $2.15 \%$ RSD was achieved with an LOD of $0.038 \mu \mathrm{g} \mathrm{L}^{-1}$ and a linear range between 0.04 and $20 \mu \mathrm{g} \mathrm{L}^{-1}$. Another approach, this time for $\mathrm{Cl}$, employed the molecular absorption of $\mathrm{AlCl}$ at $261.418 \mathrm{~nm}$ using HR-CS-AAS equipment. ${ }^{67}$ Closedvessel microwave-assisted sample digestion with $\mathrm{HNO}_{3}$ and $\mathrm{H}_{2} \mathrm{O}_{2}$ was carried out in the presence of $\mathrm{Ag}$ to trap the analyte as water-insoluble $\mathrm{AgCl}$ which was subsequently dissolved in $\mathrm{NH}_{4} \mathrm{OH}$ for injection into the graphite furnace. A mixed modifier containing $\mathrm{Al}, \mathrm{Ag}$ and $\mathrm{Sr}$, each at $1 \mathrm{~g} \mathrm{~L}^{-1}$, was injected after the sample. Pyrolysis and vaporisation temperatures were 500 and $2200{ }^{\circ} \mathrm{C}$, respectively. The LOD $\left(9 \mu \mathrm{g} \mathrm{L^{-1 }}\right)$ was 3.3 times lower than previous work based on ICP-AES. Measurement of Cs is currently an important issue, particularly in Japan, and so methodology using FAAS as well as ETAAS was revisited by Miura et al. (in Japanese). ${ }^{56}$ They recommended using $\mathrm{KNO}_{3}$ (5000 $\mathrm{mg} \mathrm{L}^{-1}$ ) as an ionisation suppressant in FAAS and $\mathrm{K}_{2} \mathrm{WO}_{4}$ $\left(1000 \mathrm{mg} \mathrm{L}^{-1}\right)$ as a matrix modifier in ETAAS. Respectively, the LODs were $0.04 \mathrm{mg} \mathrm{L}^{-1}$ and $0.18 \mu \mathrm{g} \mathrm{L}^{-1}$. Good agreement was obtained with certified concentrations in CRMs. Leaching of Al by kitchen utensils was once a hot topic but Fekete et $a l .{ }^{\mathbf{1 3 5}}$ have returned to this issue. Using ICP-AES to determine Al, they used a multilevel factorial design with temperature, contact time, $\mathrm{pH}$, salt concentration and viscosity to assess leaching from numerous items of food ware. Predictive quadratic exponential regression models indicated that $\mathrm{Al}$ utensils and ceramic ware contributed the most while $\mathrm{Al}$ from glass and stainless steel was frequently below the method LOD.

\subsection{Single and multielement applications in food and beverages}

7.2.1 Dietary intake studies. The Chinese appear to be the most targeted population for dietary intake assessment in the period under review. The content of iAs in 600 composite diet samples from Hong Kong was determined by ICP-MS..$^{\mathbf{1 3 6}}$ Combined with adult food consumption data, the average and 95 percentile exposure were derived to be 0.22 and $0.38 \mu \mathrm{g} \mathrm{kg}^{-1}$ (body weight) $\mathrm{d}^{-1}$, respectively. Unsurprisingly cereals, such as rice, and their products accounted for more than half that exposure and the authors suggested efforts be made to reduce iAs exposure. Exposure to Al was similarly assessed across southern Chinese cities using analysis of 22 food groups with $24 \mathrm{~h}$ dietary recall, and determination by ICP-MS following microwave-assisted digestion with $\mathrm{HNO}_{3} \cdot{ }^{137}$ The weekly dietary exposure was shown to be $1.5 \mathrm{mg} \mathrm{kg}^{-1}$ body weight representing $76 \%$ of the PTWI. In contrast to the Hong Kong study, wheatbased products contributed $53 \%$ of the intake. In China, a major producer and consumer of REEs, the largest usage is in agricultural plant growth regulators and livestock feed additives, which prompted the first pan-China survey of 16 REEs in foods, using ICP-MS. ${ }^{138}$ The elements Ce, La and Nd, known to be used in agriculture, were among those showing higher concentrations than the remainder although the authors speculated that this could reflect their abundance in soil.

7.2.2 Human milk and infant formula. A comparison of the Fe speciation and concentrations between human milk and infant formula indicated some differences. ${ }^{115}$ The total Fe content of pre-term and full-term human milk samples was 0.5 and $0.4 \mu \mathrm{g}$ $\mathrm{mL}^{-1}$, contrasting with 9.5 and $6.0 \mu \mathrm{g} \mathrm{mL}{ }^{-1}$ for the corresponding formulas, highlighting bio-fortification in formula milk as a compensation for reduced bioavailability. This was explained by Fe fractionation studies using SEC-ICP-MS: human milk protein fractions of high $M_{\mathrm{r}}(430-160 \mathrm{kDa})$ from colostrum and transitional milk were shown to contain more than $75 \%$ of the total Fe, corresponding to immunoglobulins (Ig) A and G with a small proportion in colostrum being ascribed to IgM (>600 kDa) and an even smaller amount associated with $M_{\mathrm{r}}$ 90$70 \mathrm{kDa}$ proteins (lactoferrin, transferrin and serum albumin). This contrasted with formula milk in which $75 \%$ Fe was bound to proteins of $M_{\mathrm{r}} 10$ to $20 \mathrm{kDa}$ and $<10 \mathrm{kDa}$. Infant exposure to $\mathrm{Hg}$ from human milk was assessed through the determination of total $\mathrm{Hg}$ in milk samples from 18 nursing mothers from Brazil, using AFS after microwave-assisted $\mathrm{HNO}_{3}$ digestion. ${ }^{139}$ Individual mean $\mathrm{Hg}$ concentrations ranged from $<0.76$ to $22.7 \mathrm{ng} \mathrm{mL} \mathrm{mL}^{-1}$ with a group mean of $6.47 \pm 6.04 \mathrm{ng} \mathrm{mL} \mathrm{m}^{-1}$. A correlation was observed between $\mathrm{Hg}$ and the mothers' consumption of fat and grains $(p=0.006$ and 0.007$)$ as well as vegetable and carbohydrate $(p=0.015$ and 0.045$)$. Although no correlation was found between human milk $\mathrm{Hg}$ levels and mothers' fish consumption frequency, a fish meal offered to the mothers on day 75 of the study resulted in increased $\mathrm{Hg}$ concentration in milk within 15 days. Despite the risk of infants being exposed to high levels of $\mathrm{Hg}$ at some point during lactation $(77.8 \%$ of samples exceeded the PTWI at least once), the authors recommended the benefits of breast feeding outweigh the potential risk. The results of a European Union-sponsored proficiency testing exercise on the determination of $\mathrm{Cd}$ and $\mathrm{Pb}$ in a soy-based infant formula powder was reported by Cordeiro et $a l .{ }^{\mathbf{1 4 0}}$ As a consequence of the low concentrations in the sample, a large number of participants reported $\mathrm{Cd}$ values below their LODs, and overestimated $\mathrm{Pb}$ because of contamination. There was a clear method influence on $\mathrm{Pb}$ values largely because AAS techniques were not sufficiently sensitive. A method for the determination of I in infant formula was proposed for adoption by the AOAC by Sullivan et al. ${ }^{\mathbf{1 4 1}}$ The procedure involved open-vessel alkaline digestion in an oven or microwave system, followed by stabilisation with $\mathrm{NH}_{4} \mathrm{OH}$ and $\mathrm{Na}_{2} \mathrm{~S}_{2} \mathrm{O}_{3}$; subsequent I determination was by ICP-MS. Repeatability was $2.27 \%$ RSD and of the determined value of I from NIST 1849 was $104 \%$ of that certified.

7.2.3 Milk and dairy products. The importance of milk as a diet staple continues to elicit the need for improved but simple methods of analysis. To this end, a new aminothioazole-containing sulfonamide resin was developed as a SPE sorbent for 
Table 3 Foods and beverages (for column 3, L = liquid, $\mathrm{S}=$ solid, $\mathrm{Sl}=$ slurry)

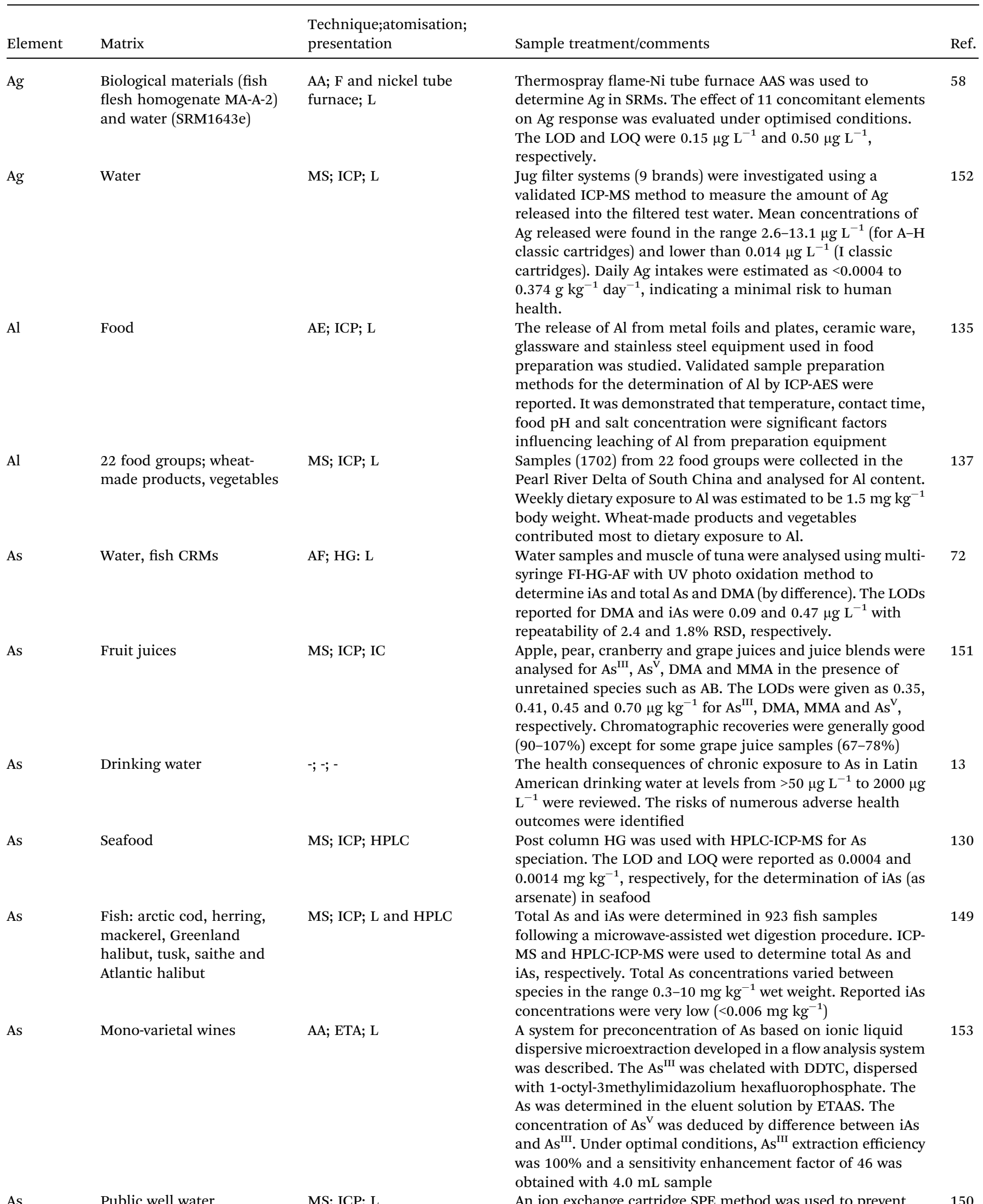

As Public well water $\quad$ MS; ICP; L

An ion exchange cartridge SPE method was used to prevent inter-conversion of As species during sampling of well waters. An ICP-SF mass spectrometer was employed to determine the 
Technique;atomisation;

Element Matrix
including cereals

As

Infant cereals

Porcine, chicken liver; food of animal tissue origin

As

Danish dietary

supplements

\begin{abstract}
Rice and rice flour
\end{abstract}
Rice grain and roots

Commercial fish oils; anchovy oil; Atlantic herring; sand eel; blue whiting and mix of oils of Atlantic herring, Atlantic cod and saithe

Juice, mineral water and coconut water
MS; ICP; L

concentrations of total As and As species. Total As found ranged from 7.2 to $210.3 \mu \mathrm{g} \mathrm{L}^{-1}$ (higher than the EU Health Limit value). $\mathrm{As}^{\mathrm{V}}$ was present at $>60 \%$ in two thirds of the samples In the first Hong Kong Total Diet Study, food samples were collected and prepared "as consumed" for analysis. Concentrations of iAs (as the sum of $\mathrm{As}^{\mathrm{III}}$ and $\mathrm{As}^{\mathrm{V}}$ ) were determined in 600 composite samples by ICP-MS. The mean and $95^{\text {th }}$ percentile of iAs exposures were 0.22 and $0.38 \mu \mathrm{g}$ $\mathrm{kg}^{-1}$ body weight day ${ }^{-1}$, respectively. Cereals and their products, particularly rice, contributed to the iAs

AA; HG; FI; AA; CV; FI

Levels of As and $\mathrm{Hg}$ in 91 infant cereals were determined by FIHG-AAS and by FI-CV-AAS, respectively. The content of these elements was lower in conventionally obtained raw materials ( $n=74$, median values: $\mathrm{Hg} 2.11 \mu \mathrm{g} \mathrm{kg}^{-1}$, As $21.0 \mu \mathrm{g} \mathrm{kg}^{-1}$ ) than in cereals produced by organic cultivation $(n=17$, median values: $\mathrm{Hg}=5.48 \mu \mathrm{g} \mathrm{kg}^{-1}$; As $96.3 \mu \mathrm{g} \mathrm{kg}^{-1}$ )

A method was developed for the separation and determination of organoarsenic species including $p$-arsanilic acid (ASA), nitarsone (NIT) and roxarsone (ROX) in animal tissue used for food. Separation and quantification of these species was achieved using HPLC coupled to UV oxidation HGAFS. An accelerated solvent extraction method was used to extract organoarsenic species from the tissue samples. The LODs and LOQs reported were $0.24,0.74,0.41$ and $0.72,2.24$ and $1.24 \mathrm{ng} \mathrm{mL}^{-1}$ for ASA, NIT and ROX, respectively Total As and iAs were determined in dietary supplements by ICP-AES and anion exchange HPLC-ICP-MS. These species were found in the range $0.58-5.0 \mathrm{mg} \mathrm{kg}^{-1}$ and 0.03 to $3.2 \mathrm{mg}$ $\mathrm{kg}^{-1}$, respectively. The findings of this study suggested that the consumption of certain dietary supplements could contribute significantly to the dietary exposure to iAs at levels close to toxicological limits

Three different methods were developed for determination of total As, total iAs, $\mathrm{As}^{\mathrm{III}}$ and $\mathrm{As}^{\mathrm{V}}$ in rice and rice flour products by ETAAS. Different selective extraction procedures were used. Calculated recoveries obtained ranged between 92 and 105\% with RSDs less than $15 \%$. The methods were successfully applied in a proficiency test organised by the International Measurement Evaluation Program (IMEP-107). For rice and rice flour samples total As and total iAs were detected at ng $\mathrm{g}^{-1}$ levels Nano SIMS was used in a high resolution mode to investigate the localisation of As in rice grain. It was reported that different treatments result in different distributions of As in the grain. The co-location of As with other elements in rice roots was also presented

Solid phase extraction was used to extract As-containing hydrocarbons from fish oil which were determined using GCICP-MS. The fish oil samples were prepared by microwaveassisted acid digestion prior to detection of total As by ICPMS. The As concentrations found in the fish oils ranged from 5.9 to $8.7 \mathrm{mg} \mathrm{kg}^{-1}$. Three dominant As containing hydrocarbons as well as one minor unidentified compound were detected in the oils using GC-ICP-MS

Sample aliquots $(20 \mu \mathrm{L})$ were placed on a tungsten coil ETA, dried then atomised. Emission spectra were produced and detected using a Czerny Turner spectrometer and CCD. In situ digestion was used to decompose organic matrices. The system was applied to the detection of Ca in juice, mineral and coconut water samples. Despite interference caused by $\mathrm{Mg}$ in mineral water samples, good agreement was obtained with ICP-OES results. The LOD and LOQ figures were 0.02 and $0.07 \mathrm{mg} \mathrm{L}^{-1}$, respectively, and method precision was reported as $3.8 \%$ RSD. 
Table 3 (Contd.)

\begin{tabular}{llr}
\hline Element & Matrix & $\begin{array}{l}\text { Techniq } \\
\text { present }\end{array}$ \\
\hline Cd & Drinking water & MS; - ; L \\
Cd & Brown rice and spinach & AA; F; L
\end{tabular}

Water; river water NRCC SLRS-4 and estuarine water NRCC SLEW2; mineral water, tap water, bottled water

Tuna fish, biscuit, black tea, rice, kasar cheese, honey, tomato paste, margarine

Cereals, vegetables, beverages, seafood and dairy products

Soya based baby food formula

Cereals, vegetables, beverages, seafood and dairy products Food CRMs

Tuna fish, biscuit, black tea, rice, kasar cheese, honey, tomato paste, margarine
MS; ICP; FI-CV

$\mathrm{AA} ; \mathrm{F} ; \mathrm{L}$

$$
\text { AA; ETA; L }
$$

MS; ICP; L

AA; ETA; L

$\mathrm{AA} ; \mathrm{ETA} ; \mathrm{L}$

AA; F; L; AA; ETA; L

$\mathrm{AA} ; \mathrm{F} ; \mathrm{L}$
Sample treatment/comments

Ref.

Exact matching ID-MS was used to determine $\mathrm{Cd}, \mathrm{Ni}$ and $\mathrm{Pb}$ in

164

drinking water. Combined measurement uncertainty was reported as less than $2 \%$ for all 3 analytes

Extraction of $\mathrm{Cd}$ from rice and spinach with $1 \mathrm{M} \mathrm{HCl}$ was followed by selective pre-concentration using SPE which achieved a 20 -fold enrichment of the sample solution. The LOQs were $0.0054 \mathrm{mg} \mathrm{kg}^{-1}$ for brown rice and $0.0022 \mathrm{mg} \mathrm{kg}^{-1}$ for spinach.

A novel microfluidic chip for introducing $0.3 \mu \mathrm{L}$ organic samples into an ICP-mass spectrometer was described and applied to the determination of $\mathrm{Cd}$ and $\mathrm{Pb}$ in distilled spirits using aqueous calibration standards. Reported LODs were 12 and $42 \mathrm{ng} \mathrm{L}^{-1}$ for $\mathrm{Pb}$ and $\mathrm{Cd}$, respectively. The $\mathrm{Cd}$ and $\mathrm{Pb}$ concentrations in 6 distilled spirits were measured and results agreed well with those determined by ICP-MS following sample preparation by microwave assisted digestion

A CPE procedure was developed for preconcentration and separation of trace levels of $\mathrm{Cd}, \mathrm{Hg}$ and $\mathrm{Sb}$ from water samples prior to their determination using FI-VG-ICP-MS. The metals were complexed with APDC and extracted with Triton X-11. Factors affecting VG were also studied and ID was used for quantification. The LODs for $\mathrm{Cd}, \mathrm{Hg}$ and $\mathrm{Sb}$ were given as $0.002,0.005$ and $0.006 \mathrm{ng} \mathrm{mL} \mathrm{m}^{-1}$, respectively

A preconcentration method was described for determination of $\mathrm{Cd}^{\mathrm{II}}, \mathrm{Cu}^{\mathrm{II}}$ and $\mathrm{Pb}^{\mathrm{II}}$ in foods. Analytical conditions including eluent type, $\mathrm{pH}$ of sample solutions and flow rates were optimised. Influence of matrix ions were also studied. The LODs were in the range $0.81 \mu \mathrm{g} \mathrm{L}^{-1}, 0.36 \mu \mathrm{g} \mathrm{L}^{-1}$ and $0.57 \mu \mathrm{g}$ $\mathrm{L}^{-1}$ for $\mathrm{Cd}, \mathrm{Cu}$ and $\mathrm{Pb}$, respectively

The $\mathrm{Cd}, \mathrm{Cr}$ and $\mathrm{Pb}$ contents in 22 kinds of food were determined using HR-CS-ETAAS. The reported method produced RSDs in the range $1.3-4.9 \%$ and recoveries between 95.0 and $104.6 \%$. The levels of $\mathrm{Pb}$ in tea leaves and $\mathrm{Cr}$ in shellfish were much higher than in other foods. The Cd levels in millet, leek and shellfish were relatively high compared to other foods

Results of a proficiency test focusing on the determinations of total $\mathrm{Cd}$ and $\mathrm{Pb}$ at very low levels in soya-based baby food formula (powder and reconstituted). Reference values independent of participants were established using ID-ICPMS

Food samples were prepared by digestion with $\mathrm{Ag}, \mathrm{HNO}_{3}$ and $\mathrm{H}_{2} \mathrm{O}_{2}$, precipitation of $\mathrm{Cl}$ as $\mathrm{AgCl}$ then dissolution in $\mathrm{NH}_{3}$ solution. Samples were directly injected onto the platform of a THFA followed by a solution of Al-Ag-Sr modifier. Using a HRCS-AA spectrometer the LOD reported for $\mathrm{Cl}$ was $9 \mu \mathrm{g} \mathrm{g}^{-1}$. When CRMs were analysed, the method gave good agreement with certified values.

See Cd ref. 63

A method for the determination of Cs by AAS using Zeemaneffect background correction was developed. The LODs reported for Cs were $0.04 \mathrm{mg} \mathrm{L}^{-1}$ by FAAS using $\mathrm{KNO}_{3}$ as ionisation inhibitor and $0.18 \mu \mathrm{g} \mathrm{L}^{-1}$ using ETAAS with potassium tungstate as matrix modifier

See Cd ref. 166 
Table 3 (Contd.)

\begin{tabular}{|c|c|c|c|}
\hline Element & Matrix & $\begin{array}{l}\text { Technique;atomisation; } \\
\text { presentation }\end{array}$ & Sample treatment/comments \\
\hline $\mathrm{Cu}$ & $\begin{array}{l}\text { Herbal medicine, tomato } \\
\text { leaves NIST } 1573 \text {, apple } \\
\text { leaves NIST } 1515\end{array}$ & AA; F; L & $\begin{array}{l}\text { A slotted quartz tube atomiser was coated with nanometer } \\
\mathrm{SiO}_{2} \text { and then used for determination of } \mathrm{Cu} \text { and } \mathrm{Zn} \text { by FAAS. } \\
\text { The new atomiser improved the linearity of calibration curves } \\
\text { considerably. The characteristic concentration ( } 1 \% \\
\text { absorption) decreased from } 6.0 \mathrm{ng} \mathrm{mL}^{-1} \text { to } 2.7 \mathrm{ng} \mathrm{mL} \mathrm{mL}^{-1} \text { for } \mathrm{Zn} \\
\text { and from } 25.0 \mathrm{ng} \mathrm{mL} \mathrm{mL}^{-1} \text { to } 10.2 \mathrm{ng} \mathrm{mL}^{-1} \text { for } \mathrm{Cu}\end{array}$ \\
\hline $\mathrm{F}$ & Milk & $\begin{array}{l}\text { Molecular absorption; } \\
\text { ETV; L }\end{array}$ & $\begin{array}{l}\text { Determination of F in milk samples was performed with a HR- } \\
\text { CS-ETAA spectrometer using the molecular absorption of CaF. } \\
\text { The method was developed using a pyrolytically coated } \\
\text { platform. The F contents of several milk samples were } \\
\text { determined by standard additions because of non-spectral } \\
\text { interferences caused by the matrix. The F content found in the } \\
\text { milk samples was in the range } 0.027-0.543 \mu \mathrm{g} \mathrm{mL} \mathrm{m}^{-1} \text {. The LOD } \\
\text { reported was } 0.26 \mathrm{ng} \mathrm{F}\end{array}$ \\
\hline $\mathrm{Fe}$ & Human milk & MS; ICP; L; MS; ICP; SEC & 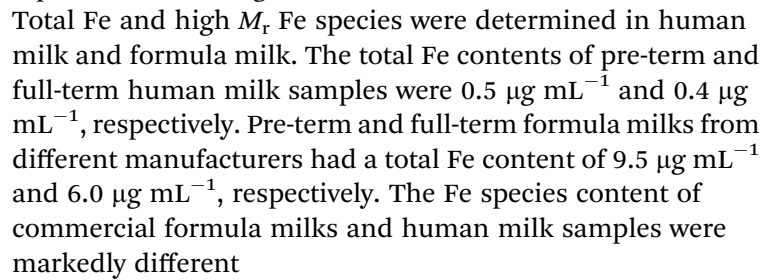 \\
\hline $\mathrm{Hg}$ & Alcoholic drinks & MS; ICP; VG & $\begin{array}{l}\text { Volatile } \mathrm{Hg} \text { vapour was released from the ethanol-containing } \\
\text { samples by UV irradiation and supplied directly to the ICP. No } \\
\text { interferences were observed from } \mathrm{Co}, \mathrm{Cu}, \mathrm{Fe} \text {. Ni and } \mathrm{Zn} \text { at } \\
5000 \text { times the concentration of } \mathrm{Hg} \text { in solution. The LOD } \\
\text { reported was substantially enhanced compared to that } \\
\text { obtained using pneumatic nebulisation }\end{array}$ \\
\hline $\mathrm{Hg}$ & Tuna fish muscle CRM 464 & $\begin{array}{l}\text { LC; MS; ICP; LC and } \\
\text { SEC; MS; ESI; L }\end{array}$ & $\begin{array}{l}\text { The binding behaviour of } \mathrm{MeHg}^{+} \text {to proteins was investigated. } \\
\text { Thus, SEC and LC were coupled to ICP-MS and ESI MS/MS to } \\
\text { sequence and identify target proteins or peptides after } \\
\text { enzymatic digestion of a model tissue (CRM 464). It was found } \\
\text { that major binding occurs to a high } M_{\mathrm{r}}(4200 \mathrm{kDa}) \text { protein. } \\
\text { Skeletal muscle myosin heavy chain was identified after } \\
\text { tryptic digestions and capillary LC-ESI-MS/MS }\end{array}$ \\
\hline $\mathrm{Hg}$ & Water; river water NRCC & MS; ICP; FI-CV & See Cd ref. 28 \\
\hline
\end{tabular}

Ref.

SLRS-4 and estuarine water NRCC SLEW2; mineral water, tap water, bottled water Seafood samples and CRM,

AF; graphite electrode; CV
Electrolytic VG coupled with AFS was used to quantify iHg and $\mathrm{MeHg}$ species in CRMs and seafood samples. An L-cysteine modified graphite cathode was used to convert $\mathrm{MeHg}^{+}$and $\mathrm{Hg}^{2+}$ to $\mathrm{Hg}$ vapour at low current. The LODs were given as 0.098 and $0.073 \mu \mathrm{g} \mathrm{L}^{-1}$ for $\mathrm{Hg}^{2+}$ and $\mathrm{MeHg}^{+}$, respectively. The RSDs for 6 replicate determinations of $2 \mu \mathrm{g} \mathrm{L}^{-1} \mathrm{Hg}$ were $3.2 \%$ and $4.7 \%$ for $\mathrm{Hg}^{2+}$ and $\mathrm{MeHg}^{+}$

The $\mathrm{Hg}^{\mathrm{II}}$ species were pre-concentrated from $\mathrm{HCl}$ solutions onto Aliquat 336-activated carbon. An enrichment factor of 1700 fold allowed the determination of the adsorbed $\mathrm{Hg}^{\mathrm{II}}$ by XRF directly at $\mu \mathrm{g} \mathrm{L}^{-1}$ levels

The $\mathrm{Hg}$ species were extracted from biological samples using 2-mercaptoethanol prior to separation by HPLC, oxidative decomposition by UV and detection by CVAFS. It was confirmed for 3 CRMs that the measured values for $\mathrm{MeHg}$ were close to certified values. The sum of the $\mathrm{MeHg}$ and the $\mathrm{iHg}$ as determined by CVAFS was similar to the total $\mathrm{Hg}$ value obtained by heat vaporisation AAS 
Table 3 (Contd.)

\begin{tabular}{|c|c|c|c|c|}
\hline Element & Matrix & $\begin{array}{l}\text { Technique;atomisation; } \\
\text { presentation }\end{array}$ & Sample treatment/comments & Ref. \\
\hline I & $\begin{array}{l}\text { Marine duck eggs, kelps, } \\
\text { laver and ganoderma } \\
\text { lucidum spirulina }\end{array}$ & AF; -; HG & $\begin{array}{l}\text { Iodine was reacted with } \mathrm{Hg}^{2+} \text { in nitric acid, extracted into } \\
\text { IBMK and then reduced to release the mercury vapour. The } \\
\text { HG content was determined using HG-AFS and related to the I } \\
\text { concentration. An LOD of } 0.038 \mu \mathrm{g} \mathrm{L}^{-1} \text { as I was reported. } \\
\text { Response was linear in the range } 0.04-20 \mu \mathrm{g} \mathrm{L}^{-1} \text {. The method } \\
\text { was applied to the detection of I in marine derived products }\end{array}$ & 71 \\
\hline I & $\begin{array}{l}\text { Infant formula and adult/ } \\
\text { paediatric formula; SRM } \\
\text { NIST } 1849\end{array}$ & MS; ICP; L & $\begin{array}{l}\text { Samples were digested by } \mathrm{KOH} \text { in an oven or open vessel } \\
\text { microwave system. I was stabilised with } \mathrm{NH}_{4} \mathrm{OH} \text { and sodium } \\
\text { thiosulfate and taken to volume, then filtered and either } \\
\text { diluted or analysed directly by ICP-MS. Average repeatability } \\
\text { for analysis of milk powder was } 2.27 \% \mathrm{RSD} \text {, and for dietary } \\
\text { supplement tablet SRM, } 4.2 \% \mathrm{RSD}\end{array}$ & 141 \\
\hline $\mathrm{Na}$ & Bread and dough & AA; -; L & $\begin{array}{l}\text { A comparison was made between an indirect AAS method } \\
\text { (measuring Na) and two potentiometric methods (measuring } \\
\mathrm{Cl} \text { ) for the determination of salt in bread and dough. It was } \\
\text { reported that levels of Na found were not necessarily } \\
\text { consistent with the } \mathrm{Cl} \text { content measured potentiometrically }\end{array}$ & 167 \\
\hline $\mathrm{Ni}$ & Drinking water & MS; -; L & See Cd ref. 163 & 164 \\
\hline $\mathrm{Ni}$ & Milk, yoghurt & AA; F; L & $\begin{array}{l}\text { An SPE method using aminothioazole-containing sulfonamide } \\
\text { resin was used to extract Ni and Pb from milk and yoghurt } \\
\text { samples. The metals were determined using slotted tube atom } \\
\text { trap-AAS. The method provided an enhancement of } 50 \text { - and } \\
\text { 350-fold in the sensitivity of Ni and Pb, respectively. The LODs } \\
\text { reported were } 0.75 \mathrm{ng} \mathrm{mL}^{-1} \text { for Ni and. } 0.15 \mathrm{ng} \mathrm{mL}^{-1} \text { for Pb }\end{array}$ & 142 \\
\hline $\mathrm{Pb}$ & Drinking water & MS; -; L & See Cd ref. 164 & 164 \\
\hline $\mathrm{Pb}$ & Distilled spirits & MS; ICP; L & See Cd ref. 48 & 48 \\
\hline $\mathrm{Pb}$ & $\begin{array}{l}\text { Tuna fish, biscuit, black } \\
\text { tea, rice, kasar cheese, }\end{array}$ & AA; F; L & See Cd ref. 166 & 166 \\
\hline
\end{tabular}

honey, tomato paste, margarine

Cereals, vegetables, beverages, seafood and dairy products Milk, yoghurt

Wine and associated materials

AA; ETA; L

AA; ETA; L

AA; ETA; L

AA; F; L

Water-trace elements (NWTMDA-61.2); typical Diet (NIST SRM 1548a); juices, tomato paste, corn and green peas Food samples; milk and spinach CRMs; onion, garlic SLRS-4) and estuarine water (NRCC SLEW2); mineral water, tap water,

\section{bottled water}

Vegetables - spinach, onions, carrots

Iodine was reacted with $\mathrm{Hg}^{2+}$ in nitric acid, extracted into BMK and then reduced to release the mercury vapour. The concentration. An LOD of $0.038 \mu \mathrm{g} \mathrm{L}^{-1}$ as I was reported. Response was linear in the range $0.04-20 \mu \mathrm{g} \mathrm{L}^{-1}$. The method we de detived products thiosulfate and taken to volume, then filtered and either repeatability (measuring $\mathrm{Na}$ ) and two potentiometric methods (measuring $\mathrm{Cl}$ ) for the determination of salt in bread and dough. It was reported that levels of $\mathrm{Na}$ found were not necessarily See Cd ref. 163

An SPE method using aminothioazole-containing sulfonamide 350 -fold in the sensitivity of $\mathrm{Ni}$ and $\mathrm{Pb}$, respectively. The LODs reported were $0.75 \mathrm{ng} \mathrm{mL}^{-1}$ for $\mathrm{Ni}$ and. $0.15 \mathrm{ng} \mathrm{mL}^{-1}$ for $\mathrm{Pb}$

See Cd ref. 48

Molecular absorption; ETA; S

MS; ICP; FI-CV

AF; HG; HPLC
See Cd ref. 63

See Ni ref. 142

An atomiser with a graphite filter insert and a Pd-Mg matrix modifier was optimised for determination of $\mathrm{Pb}$ in wines and associated materials. The LOD of the method was $0.0025 \mathrm{mg} \mathrm{L}^{-1}$. A CPE method developed for pre-concentration and simultaneous determination of $\mathrm{Pb}$ and $\mathrm{Sn}$ by FAAS. Calibration graphs for $\mathrm{Pb}$ and $\mathrm{Sn}$ were linear in concentration ranges 5-1000 and 10-5000 $\mu \mathrm{g} \mathrm{L}^{-1}$ with LODs of 1.40 and 2.86 $\mu \mathrm{g} \mathrm{L}^{-1}$. The procedure was validated by analysis of SRMs A HR-CS-ETAAS instrument was used to measure the $\mathrm{S}$ content in foods and CRMs using the molecular absorption of carbon monosulfide. An Ir coated graphite tube/platform was used in combination with a solid sampling approach. Calibration was achieved using a $\mathrm{Na}_{2} \mathrm{~S}$ standard and the response was linear between the LOQ of $0.01 \mu \mathrm{g}$ and $10 \mu \mathrm{g}$ of S. The LOD was reported as $3.5 \mathrm{ng} \mathrm{S}$

See Cd ref. 28

A method for determining Sb species in vegetables was developed using HPLC separation combined with HG-AFS. Extraction was achieved using EDTA as it maintained the stability of the Sb species during the analytical process. The LODs and precision (RSD) values obtained for $\mathrm{Sb}^{\mathrm{V}}, \mathrm{Sb}^{\mathrm{III}}$ and trimethyl $\mathrm{Sb}^{\mathrm{V}}$ were $0.08,0.07$ and $0.9 \mu \mathrm{g} \mathrm{L}^{-1}$ and 5.0, 5.2 and $4.7 \%$, respectively. Extraction of total $\mathrm{Sb}$ content from the vegetables ranged between 50 and $70 \%$ depending on the vegetable and the species extracted 
Table 3 (Contd.)

\begin{tabular}{|c|c|c|c|}
\hline Element & Matrix & $\begin{array}{l}\text { Technique; atomisation; } \\
\text { presentation }\end{array}$ & Sample treatment/comments \\
\hline $\mathrm{Se}$ & Food matrices; CRMs & AA; ETA; FI-HG & $\begin{array}{l}\text { Optimisation of the determination of Se in food matrices } \\
\text { using FI-HG-ETAAS was described. When the method was } \\
\text { used for CRMs recoveries }>95 \% \text { were obtained for all matrices }\end{array}$ \\
\hline Se & Yeast & $\begin{array}{l}\text { MS; ES; LC; MS; } \\
\text { ICP; HPLC }\end{array}$ & $\begin{array}{l}\text { Reversed phase/hydrophilic ion interaction LC ES hybrid } \\
\text { quadrupole trap/orbitrap MS was used for separation and } \\
\text { speciation of Se metabolites in a Se-rich yeast. Overall, } 64 \\
\text { metabolites were detected of which } 21 \text { were previously } \\
\text { unreported. ICP-MS was used to quantify the identified } \\
\text { metabolites }\end{array}$ \\
\hline $\mathrm{Se}$ & Wheat proteins & MS; ICP; S & $\begin{array}{l}\text { A LA-ICP-MS instrument was used to identify the position of } \\
\text { Se-containing proteins in large } 2 \mathrm{D} \text { electrophoresis gels. } \\
\text { Electrospray orbitrap MS/MS was then used to identify the } \\
\text { proteins. The method was used for identification and semi- } \\
\text { quantitative determination of Se storage proteins in wheat }\end{array}$ \\
\hline Se & $\begin{array}{l}\text { Dietary supplements; } \\
\text { wheat gluten (NIST SRM } \\
8418 \text { ) }\end{array}$ & $\begin{array}{l}\text { AE; MIP; TD; AE; } \\
\text { ICP; HG }\end{array}$ & $\begin{array}{l}\text { The determination of Se was carried out using a combination } \\
\text { of HG-headspace solid phase microextraction followed by } \\
\text { thermal desorption coupled to MIP-OES and continuous HG- } \\
\text { ICP-OES systems. Using this method for analysis of NIST SRM } \\
8418 \text {, Se concentration was found to be } 2.455 \pm 0.25 \mu \mathrm{g}^{-1} \\
\text { compared to the certified value of } 2.58 \pm 0.19 \mu \mathrm{g} \mathrm{g}^{-1}\end{array}$ \\
\hline Se & $\begin{array}{l}\text { Brazil nuts, apricots, white } \\
\text { beans, rice flour, milk } \\
\text { powder; dogfish muscle } \\
\text { (CRM DORM-2) }\end{array}$ & AA; F; HG & $\begin{array}{l}\text { The Se was pre-concentrated into an atomically imprinted } \\
\text { polymer, eluted and determined online by HG-FAAS. The LOD } \\
\text { and LOQ were reported as } 53 \text { and } 177 \mathrm{ng} \mathrm{L}^{-1} \text {, respectively. The } \\
\text { preconcentration factor, consumptive index and } \\
\text { concentration efficiency were } 232,0.06 \mathrm{~mL} \text { and } 58 \mathrm{~min}^{-1} \text {, } \\
\text { respectively. CRM DORM-2 was analysed to confirm the } \\
\text { validity of the method }\end{array}$ \\
\hline Se & Biologically related SRM's & MS; ICP; L & $\begin{array}{l}\mathrm{CH}_{4} \text { was mixed with Ar in the ICP to remove the }{ }^{40} \mathrm{Ar}^{2+} \\
\text { interference on the }{ }^{80} \mathrm{Se} \text { isotope. An elaborate evaporation } \\
\text { procedure was used to remove the } \mathrm{Br} \text { from the digestion solution } \\
\text { and thus avoid the interference }{ }^{79} \mathrm{BrH}^{+} \text {on }{ }^{80} \mathrm{Se} \text {. The method was } \\
\text { used to determine Se in } 50 \text { biologically related SRMs }\end{array}$ \\
\hline Se & $\begin{array}{l}\text { Food samples, alcoholic } \\
\text { and non-alcoholic } \\
\text { beverages }\end{array}$ & AA; F; L & 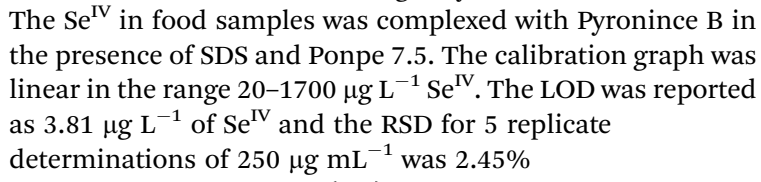 \\
\hline $\mathrm{Si}$ & Typical Diet (NIST 1848a) & MS; ICP; L & $\begin{array}{l}\text { The interference standard (IFS) method was applied to remove } \\
\text { bias in the determination of Si in Typical Diet NIST SRM } 1848 \\
\text { by ICP-MS. Using IFS, no statistically significant difference at } \\
95 \% \text { confidence levels was found between the reference and } \\
\text { determined values. The LODs of } 6.0,5.0 \text { and } 8.0 \mu \mathrm{L}^{-1} \text { were } \\
\text { calculated for determinations at } m / z 28 \text {, or using } 28 / 37 \text { and } \\
28 / 38 \text { signal ratios, respectively }\end{array}$ \\
\hline Sn & Water-trace elements & AAS; F; L & See $\mathrm{Pb}$ ref. 27 \\
\hline
\end{tabular}

Ref.

(NWTMDA-61.2); typical Diet (NIST SRM 1548a); juices, tomato paste, corn and green peas

Separation of $\mathrm{Tl}$ species was based on an ionic liquid-assisted ion pairing DLLME method. Complexation and ion pairing of the $\mathrm{Tl}^{\mathrm{III}}$ was followed by elution and extraction in the organic phase. $\mathrm{Tl}^{\mathrm{I}}$ remained in the aqueous phase and was determined by ICP-MS. Total $\mathrm{Tl}$ was determined by direct sample introduction into ICP-MS. The LOD given for Tl was $0.4 \mathrm{ng} \mathrm{L}^{-1}$ See $\mathrm{Cu}$ ref. 57

Foodstuffs consumed in China were investigated to provide data for establishing and revising food safety standards for REEs. A total of 1231 samples were analysed and the concentrations for 16 REEs determined. Mean values for total REE oxides varied from $0.052 \mathrm{mg} \mathrm{kg}^{-1}$ to $0.337 \mathrm{mg} \mathrm{kg}^{-1}$ 
Table 3 (Contd.)

\begin{tabular}{lll}
\hline Element & Matrix & $\begin{array}{l}\text { Technique;atomisation; } \\
\text { presentation }\end{array}$ \\
\hline $\begin{array}{l}\text { Various } \\
(17)\end{array}$ & Apples & AE; ICP; L
\end{tabular}

Various $\quad$ Pumpkin seeds $\quad$ XRF; -; S
(12)

Various $\quad$ Seafood, CRMs
(8)

Various

(12)

Various

(6)

Various

(14)

Various

(11)

Various

(14)

Various

(10)

Various

(16)
Brazilian wine

Herbal supplements: Panax

Ginseng, Golden Seal,

Ginger Root, St John's

Wort, Green Tea and

Valerian root

Brown rice flour CRM

ICP; L; AA; ETA; L

AE; ICP; L

Propolis

Milk powder

$\mathrm{AE} ; \mathrm{ICP} ; \mathrm{L}$

Organic and conventional milk

Cows milk; milk powder

(NCS ZC73015)
Sample treatment/comments

Ref.

The concentrations of major and minor elements in apples

146

(whole, peel and flesh) were determined by ICP-AES following digestion of samples using a microwave system. The LODs of elements were from 0.01 to $14.7 \mu \mathrm{g} \mathrm{g}^{-1}$. Recoveries from added spikes were reported in the range 88 to $115 \%$ Pumpkin seeds from Japan, New Zealand, Mexico and Tonga were freeze dried, pulverized and pressed into discs prior to the determination of 12 elements by EDXRF. Pumpkin samples (118) were analysed quantitatively and the results subjected to multivariate analysis. Models were established which allowed the discrimination of the four different origins of the seeds with 70 to $80 \%$ accuracy

The bio-accessibility of toxic elements ( $\mathrm{Al}, \mathrm{Cd}, \mathrm{Hg}$ and $\mathrm{Pb}$ ) and essential elements ( $\mathrm{Cu}, \mathrm{Mn}, \mathrm{V}$ and $\mathrm{Zn}$ ) was assessed using ICPMS following a continuous sample leaching procedure with artificial saliva or gastric juice. The 8 elements were determined in CRMs and in actual seafood samples. Mass balance was verified by carrying out total digestion of the remaining sample residues

The concentrations of transition metals in herbal supplements were determined directly by LA-ICP-MS and by conventional ICP-MS using liquid samples prepared using closed vessel digestion. Comparison of results showed that LA-ICP-MS was a rapid and pragmatic method of determining the element concentrations

A brown rice flour CRM containing As, Cd, Cu, Fe, Mn, and $\mathrm{Zn}$ was developed by drying and freeze grinding a fresh sample of brown rice. Each element was determined by two independent analytical methods. Element concentrations were reported to be in the range $0.280 \mathrm{mg} \mathrm{kg}^{-1}$ As to $31.8 \mathrm{mg} \mathrm{kg}^{-1} \mathrm{Zn}$ Natural propolis samples from Bahia State in Brazil were prepared using two different digestion methods then analysed using ICP-AES. A CRM was used to validate the procedure. The optimised microwave-assisted digestion procedure gave recoveries around $89-103 \%$ and precision better than 5\% RSD for most samples

Sample preparation based on focused microwave-induced combustion and by microwave-assisted wet digestion was used for milk powder digestion prior to determination of $\mathrm{Ba}$, $\mathrm{Ca}, \mathrm{Co}, \mathrm{Cr}, \mathrm{Cu}, \mathrm{Fe}, \mathrm{Mg}, \mathrm{Mn}, \mathrm{Sr}, \mathrm{V}$ and $\mathrm{Zn}$ by ICP-AES. A reported advantage of focused microwave-induced combustion was the possibility to digest larger sample masses (up to $3 \mathrm{~g}$ )

Ten essential trace elements and four toxic elements were determined in milk from organic and conventional farms in NW Spain. Samples were acid digested and analysed by ICPMS. It was reported that essential trace element concentrations were significantly lower in organic in comparison with conventional milk but that little difference was found for toxic elements

An HR-CS-AAS instrument was used to directly determine 10 elements in Brazilian red wines. The results agreed within $99 \%$ of confidence with those obtained by ICP-AES. Four elements; K, Mn, $\mathrm{Rb}$ and $\mathrm{Sr}$, were found to be the best indicators of the origin of the wines based on PCA Milk samples were treated with oxalic acid and $\mathrm{HNO}_{3}$ to precipitate proteins prior to analysis by ICP-TOF-MS for 16 elements. Analytical validity was assessed by applying the method to the analysis of NCS ZC73015 milk powder. Results found were in agreement with certified values with RSDs $<10 \%$. Samples were also prepared using microwave assisted digestion and results of both methods compared 
use with FAAS to determine $\mathrm{Ni}$ and $\mathrm{Pb}$ in milk and yoghurt. ${ }^{142} \mathrm{~A}$ combination of the SPE resin and use of slotted tube atom trap FAAS yielded preconcentration factors of 50 and 350 and resulted in LODs of $0.75 \mathrm{ng} \mathrm{mL}^{-1}$ and $0.15 \mathrm{ng} \mathrm{mL} \mathrm{m}^{-1}$, respectively. The $\mathrm{Pb}$ concentrations in milk and yoghurt collected in Turkey were in the ranges of 15-61 ng mL ${ }^{-1}$ and 21-42 $\mathrm{ng} \mathrm{g}^{-1}$. Determination of $\mathrm{F}$ in milk was achieved indirectly through the molecular absorption of CaF using HR-CS-ETAAS. ${ }^{66}$ An optimised amount of additional $\mathrm{Ca}(40 \mu \mathrm{g})$ was added to the sample in the graphite tube. Standard additions were required because of non-spectral interferences; the LOD achieved was $0.026 \mu \mathrm{g}$ $\mathrm{mL}^{-1}$ (characteristic mass was $0.13 \mathrm{ng}$ ) and the precision was $<15 \%$ RSD. The high Ca and protein concentrations found in milk products can have a deleterious effect on the quantification of many elements by ICP-MS and so precipitation of these matrix components by oxalic acid and $\mathrm{HNO}_{3}$ was proposed to eliminate several known $\mathrm{Ca}$ spectral interferences. ${ }^{54}$ Precipitation of Ca occurred on addition of $350 \mu \mathrm{L}$ of oxalic acid $\left(50 \mathrm{~g} \mathrm{~L}^{-1}\right)$ to $5 \mathrm{~mL}$ milk sample followed by $100 \mu \mathrm{L}$ $65 \% \mathrm{HNO}_{3}$ for precipitation of protein prior to centrifugation. Trace and ultra-trace analysis of 16 elements (As, B, Be, Co, Cr, $\mathrm{Cs}, \mathrm{Ga}, \mathrm{Li}, \mathrm{Mo}, \mathrm{Mn}, \mathrm{Ni}, \mathrm{Sb}, \mathrm{Se}, \mathrm{Sn}, \mathrm{Tl}$ and V) was then possible using ICP-TOF-MS with Rh as internal standard.

Methodologies to assess the differences in element concentrations between organic and conventionally-farmed produce have occasionally appeared in this review. Rey-Crespo et al. ${ }^{143}$ concurred with previous authors in noting that organic milk has lower concentrations than conventional milk. Using ICP-MS, they particularly noted differences (organic vs. conventional milk, respectively) in $\mathrm{Cu}\left(41.0\right.$ and $\left.68.9 \mu \mathrm{g} \mathrm{L} \mathrm{L}^{-1}\right), \mathrm{I}(78$ and $265 \mu \mathrm{g}$ $\left.\mathrm{L}^{-1}\right)$, Se (9.4 and $\left.19.2 \mu \mathrm{g} \mathrm{L}^{-1}\right)$ and $\mathrm{Zn}\left(3326\right.$ and $\left.3933 \mu \mathrm{g} \mathrm{L}^{-1}\right)$. Seasonal differences were also seen in organic milk, especially in As and $\mathrm{Fe}$ ( $65 \%$ and $13 \%$ increase) potentially because winter feed concentrate was used.

7.2.4 Cereals, flour and rice. Motivated by the strict control of heavy metals in infant food, particularly cereals, HernandezMartinez and Navarro-Blasco ${ }^{\mathbf{1 4 4}}$ surveyed 91 samples, covering 10 different Spanish manufacturers, for total As and $\mathrm{Hg}$ determined by HG-AAS. Median concentrations of $\mathrm{As}$ and $\mathrm{Hg}$ in organic cereal products (5.48 and $\left.96.3 \mu \mathrm{g} \mathrm{kg} \mathrm{kg}^{-1} ; n=17\right)$ were higher than those conventionally produced $(2.11$ and $21.0 \mu \mathrm{g}$ $\left.\mathrm{kg}^{-1} ; n=74\right)$. The products with the highest $\mathrm{Hg}$ content came from ingredients susceptible to particulate contamination such as gluten-free or cocoa-based cereals, while high As content corresponded to rice-based products, and, in several cases, inadmissible infant risk was highlighted. Moore et al. ${ }^{\mathbf{1 0 0}}$ used nanoSIMS, a powerful technique used to map the distribution of subcellular As, to show As was co-localised with $\mathrm{S}$ in rice grain and roots, suggesting that $\mathrm{As}^{\mathrm{III}}$-phytochelatin complexes are an important detoxification mechanism for As. They also showed that the speciation of the As in irrigation water had an influence on the localisation of As in the grain. Rice plants fed with As ${ }^{\text {III }}$ showed an accumulation of As in the aleurone (bran husk) layer, whereas high DMA-content grains tended to show higher As content in the subaleurone region.

A reasonably rapid technique for the precise location and nature of Se-metalloproteins extracted from wheat flour was devised by Bianga et al. ${ }^{99}$ Two, 1D separations of extracts were run using IEF and SDS-PAGE. Proteins were located by staining and those containing Se identified by LA-ICP-MS scanning. With knowledge of the position of the selenoproteins, 2D separation was then carried out and LA-ICP-MS scanning performed solely in the areas corresponding to these proteins. This approach avoided having to carry out time-consuming scans of the entire 2D electrophoretogram. The Se-protein hotspots were then cut from the gels for trypsin digestion and determined using dual HPLC-ICP-MS/ESI-MS. The Se-rich storage proteins thus identified were shown to belong to the glutenin and $\gamma$-gliadin groups with both the cysteine and methionine forms being present. The authors identified Se-S substitution for the first time in organisms other than in yeast.

7.2.5 Vegetables, fruits and nuts. Molecular absorption spectrometry was used for indirect $\mathrm{S}$ determination in dried vegetable material using the carbon monosulfide hyperfine rotational line $(258.056 \mathrm{~nm})$ generated using HR-CS-ETAAS. ${ }^{65}$ Solid sampling techniques deposited $2-3 \mu \mathrm{g}$ into the graphite tube/platforms, previously coated with Ir, and Pd matrix modifier was added; the LOD was $0.01 \mu \mathrm{g}$. The $\mathrm{S}$ content of onion and garlic samples ranged from 4.13 to $7.34 \mathrm{mg} \mathrm{g}^{-1}$. Food authenticity assessment using multi-element determinations has frequently been highlighted in this review. A Japanese team used XRF spectrometric analysis of pumpkin seeds to determine their geographical provenance. ${ }^{145}$ The origins of samples from four countries (Japan, Mexico, New Zealand and Tonga) were discriminated using LDA models based on the concentrations of $\mathrm{Ba}, \mathrm{Br}, \mathrm{Ca}, \mathrm{Cu}, \mathrm{Fe}, \mathrm{Mn}, \mathrm{Mo}, \mathrm{Ni}, \mathrm{P}, \mathrm{Rb}, \mathrm{Sr}$ and $\mathrm{Zn}$, with an accuracy of $70-80 \%$. The authors recommended XRF spectrometry as a method of authenticity because of easy sample preparation procedures compared to the need for digestion when employing the usual analytical techniques; better accuracy would be required, however, if this technique were to be applied in a commercial or legal setting! A speciation method for $\mathrm{Sb}$ in vegetables was developed by Olivares et al. ${ }^{74}$ using HPLC-HG-AFS to quantify $\mathrm{Sb}^{\mathrm{III}}, \mathrm{Sb}^{\mathrm{V}}$ and TMSb. Ultrasound extraction, in preference to mechanical extraction, was carried out for $60 \mathrm{~min}$, with $0.01 \mathrm{M}$ EDTA at pH 2.5 which also acted to stabilise $\mathrm{Sb}^{\mathrm{V}}$. The extraction rates for carrots, onions and spinach ranged from 50 to $60 \%$ leading the authors to postulate the presence of another as yet uncharacterised species such as Sb-phytochelatins. With an LOD of $80 \mathrm{ng} \mathrm{g}^{-1}, \mathrm{Sb}^{\mathrm{V}}$ was only detected in the roots of a few samples of spinach and onion. Motivated by assessing the health effects of consuming apples, Cindric et al. ${ }^{146}$ used ICP-AES for a detailed analysis of Croatian apples. A total of 16 samples (1 $\mathrm{kg}$ total each) of fruit were collected from one orchard. Closed and open microwave-assisted digestion preceded the measurement of 21 elements, seven of which were below their LODs. The authors tabulated reference ranges were: $\mathrm{K}: 39-47 \mathrm{mg} \mathrm{g}^{-1}$; Na: 9$14 \mathrm{mg} \mathrm{g}^{-1}$, Mg: 3-7 $\mathrm{mg} \mathrm{g}^{-1}$; Sr 0.7-2.8 $\mu \mathrm{g} \mathrm{g}^{-1}$ and $\mathrm{Zn} \mathrm{3-7} \mu \mathrm{g} \mathrm{g}^{-1}$. Several elements were only detected in the peel, e.g., Mn $(4-6 \mu \mathrm{g}$ $\left.\mathrm{g}^{-1}\right)$ and $\mathrm{Cd}\left(0.4-1.1 \mu \mathrm{g} \mathrm{g}^{-1}\right)$. These data may also be beneficial for future authenticity work.

7.2.6 Fish and seafood. Contamination offish and seafood by toxic elements has been known for a long time, however, the fate and persistence of the contaminant once ingested is just being 
elucidated. In a pilot study, Krystek et al. ${ }^{\mathbf{1 4 7}}$ positively correlated $\mathrm{MeHg}$ concentration in fingernail clippings, determined by GCICP-MS, with human fish consumption. The fish oils used to make commercial fish feed have been shown to contain at least three dimethylarsinoyl hydrocarbons using GC-ICP-MS. ${ }^{148}$ After hexane-methanol-water extraction and clean-up using weak anion exchange SPE, the fish oil $\mathrm{MeOH}$ extracts, containing 78 to $92 \%$ of the total As, were analysed by GC-ICP-MS. Identification using GC-MS and TOF-QMS confirmed the As-containing hydrocarbons to be $\mathrm{C}_{17} \mathrm{H}_{38} \mathrm{AsO}, \mathrm{C}_{19} \mathrm{H}_{42} \mathrm{AsO}$ and $\mathrm{C}_{23} \mathrm{H}_{38} \mathrm{AsO}$; a fourth eluting close to the $\mathrm{C}_{17}$ hydrocarbon remained un-identified. The oils analysed were prepared from: anchovy; Atlantic herring; sand eel; blue whiting and a commercial mixed fish oil (Atlantic herring-Atlantic cod-saithe). Decontamination of two of the original fish oils by activated charcoal and steam deodorisation reduced the total As content by 10 to $20 \%$, reducing all three dimethylarsinoyl hydrocarbons. In the case of herring oil, the process removed all the dimethylarsinoyl $\mathrm{C}_{21}$-hydrocarbon and considerably reduced the others. A survey $(n=923)$ of total As and iAs, measured by ICP-MS and HPLC-ICP-MS, in Norwegian fish fillets, representing seven species caught in 40 locations, was carried out by Julshamn et al. ${ }^{149}$ Concentrations of organic As ranged from 0.3 to $110 \mathrm{mg} \mathrm{kg}{ }^{-1}$ according to species while iAs concentrations in all samples were very low $\left(<0.006 \mathrm{mg} \mathrm{kg}^{-1}\right)$. From this latter observation, the authors called into question the assumptions on iAs made by the European Food Safety Authority in a recent Opinion on As in Food (2009) which considered iAs concentrations of 0.03 and $0.10 \mathrm{mg} \mathrm{kg}{ }^{-1}$ as possible in fish and seafood, respectively. A continuous leaching method for assessing oral bio-accessibility, discussed in last year's review, was used to assess various toxic and essential trace elements in seafood. ${ }^{52} \mathrm{~A}$ continuous sequential flow of saliva and gastric juice was passed over the powdered sample, placed in a mini-column; the leachate then flowed directly into the nebuliser of the ICP-mass spectrometer. Freeze-dried samples of five species of both fish and shellfish were sourced from the French $2^{\text {nd }}$ Total Diet Study and the Callipso study. The mean bio-accessibility of toxic metals varied enormously between seafood species: Aluminium was highest in crab; Cd was between 60 and 100\% across all species studied, $\mathrm{Hg}$ was most bio-available from crab and saithe. Only shrimp and scallops showed bio-availability lower than $20 \%$. The mean bio-availability for the essential elements studied was typically between 30 and 100\%, except Mn in salmon (20\%); V in shrimp (20\%) and $\mathrm{Zn}$ in tuna.

7.2.7 Meat and offal. A new validated method was proposed allowing the speciation of $\mathrm{Hg}$ in animal tissue for the first time. ${ }^{25}$ Inorganic $\mathrm{Hg}$ and $\mathrm{MeHg}$ species from liver samples were quantitatively extracted using closed-vessel microwave-assisted extraction into alkali, subsequently ethylated and absorbed onto a polydimethoxylsiloxane-coated SPME fibre. Desorption into a GC-AF spectrometer via pyrolysis yielded LODs of 31.8 and $52.5 \mathrm{ng} \mathrm{g}^{-1}$ for $\mathrm{MeHg}$ and $\mathrm{Hg}^{2+}$, respectively, allowing an improvement of 5.5 to 6 times compared to non-SPME methods. In liver samples from red deer, $\mathrm{MeHg}$ was detected in three out of four samples (78-425 $\mathrm{ng} \mathrm{g}^{-1}$ ) and not detected in either wild boar samples. Residual organic As species in animal feed were determined in animal tissue by HPLC-HG-AFS. ${ }^{73}$ The species, extracted from samples of chicken and pork livers using ASE, identified and measured were $p$-arsenilic acid, nitarsone and rozarsone. Separation occurred on a $\mathrm{C}_{18}$ column with a mobile phase composition of $\mathrm{KH}_{2} \mathrm{PO}_{4}$ and $0.1 \% \mathrm{CF}_{3} \mathrm{COOH}$ at pH 2.43. This approach yielded LODs of $0.24,0.74$ and $0.41 \mathrm{ng} \mathrm{mL}{ }^{-1}$ for $p$-arsenilic acid, nitarsone and rozarsone, respectively, and LOQs of $0.72,2.24$ and $1.24 \mathrm{ng} \mathrm{mL}{ }^{-1}$. The range of As species found in these animal tissues purchased in a Chinese market was 3-9 $\mathrm{ng} \mathrm{mL}^{-1}$. Unfortunately the concentrations $(\mathrm{w} / \mathrm{w})$ for the actual samples were not presented and it is difficult to comprehend why this paper was accepted for publication.

7.2.8 Drinking water and non-alcoholic beverages. Drinking water contamination by As is well documented in Asia, particularly Bangladesh, but little is understood of the related health consequences in other regions. The As species (As ${ }^{\mathrm{III}}$ and $\mathrm{As}^{\mathrm{V}}$ ) of well water from several regions of Hungary were measured by SF-ICP-MS with samples being stabilised by infield anion exchange. ${ }^{150}$ The results indicate that total As concentration, which ranged from 7.2 to $210.3 \mu \mathrm{g} \mathrm{\textrm {L } ^ { - 1 }}$, exceeded international limits $\left(10 \mu \mathrm{g} \mathrm{L}^{-1}\right)$ in 22 of the 23 samples analysed. However, two-thirds of the samples presented with $<60 \%$ of the As in the higher oxidation state, which is less toxic than $\mathrm{As}^{\mathrm{III}}$. The authors also found a relationship between the concentration of $\mathrm{As}^{\mathrm{V}}$ and the concentrations of Mo, $\mathrm{V}$ and $\mathrm{W}\left(r^{2}=0.65\right)$. Latin America is known to have a long history of widespread As contamination, with an estimated 4.5 million people exposed to As levels $>50 \mu \mathrm{g} \mathrm{\textrm {L } ^ { - 1 }}$. To redress this, McClintock et al. ${ }^{\mathbf{1 3}}$ undertook a systematic review of 82 peer-reviewed papers and reports. They concluded the reviewed work supported important links between high levels of chronic As exposure and elevated health risks as well as evidence of polymorphisms that influence susceptibility to such risks.

Separation and quantification of As species in several types of fruit juice using IC-ICP-MS was accomplished by Conklin and Chen. ${ }^{151}$ The LODs of the four species: $\mathrm{As}^{\mathrm{III}}, \mathrm{As}^{\mathrm{V}}$, DMA and MMA (AB was not retained during $\mathrm{IC}$ ) were $0.35,0.7,0.41$ and $0.45 \mu \mathrm{g}$ $\mathrm{kg}^{-1}$; their recovery ranged from 90 to $107 \%$ for most juices except for grape juice in which the recoveries were between 67 and $78 \%$. Point-of-use water purification systems include filters which use Ag to inhibit microbial growth. Concerns that this could potentially trigger argyria prompted a study of nine jug filtration systems available in Poland. ${ }^{152}$ Determined by ICP-MS, the released Ag content ranged between 2.6 and $13.1 \mu \mathrm{g} \mathrm{L^{-1 }}$ from filters containing modified-activated charcoal while one filter which used non-modified activated charcoal only released an $\mathrm{Ag}$ concentration $<0.014 \mu \mathrm{g} \mathrm{\textrm {L } ^ { - 1 }}$. Based on a daily consumption of $2 \mathrm{~L}$, the authors determined a maximum exposure rate of $0.374 \mu \mathrm{g} \mathrm{kg}^{-1} \mathrm{day}^{-1}$, a hazard quotient $<0.075$, and concluded jug filters posed no long-term threat to health. Although usually found in very low levels, $\mathrm{Tl}$, especially $\mathrm{Tl}^{\mathrm{III}}$, toxicity is much greater than that of $\mathrm{Cd}, \mathrm{Hg}$ or $\mathrm{Pb}$, and its presence may affect the quality of drinking water. As a consequence of this low abundance, a novel sensitive speciation technique, based on determination by ICP-MS, was developed by Escudero et al. ${ }^{32}$ Complexation of $\mathrm{Tl}^{\mathrm{III}}$ with $\mathrm{Cl}^{-}$was followed by ion pairing DLLME using the ionic liquid CYPHOS® IL 101 
(tetradecyl(trihexyl)phosphonium chloride). The organic phase, which comprised $\mathrm{CCl}_{4}$ and $\mathrm{EtOH}$, only contained the $\mathrm{Tl}^{\mathrm{II}}$ complex since $\mathrm{Tl}^{\mathrm{I}}$ does not complex with $\mathrm{Cl}^{-}$. The LOD of this technique was $0.4 \mathrm{ng} \mathrm{L}^{-1}$ with precisions for $\mathrm{Tl}^{\mathrm{I}}$ and $\mathrm{Tl}^{\mathrm{III}}$ of $1.3 \%$ RSD and $1.5 \%$ RSD. In river water samples $(n=4)$, the concentration ranges of $\mathrm{Tl}^{\mathrm{I}}$ and $\mathrm{Tl}^{\mathrm{III}}$ were $0.0-0.06 \mu \mathrm{g} \mathrm{L}^{-1}$ and $0.04-0.08 \mu \mathrm{g} \mathrm{L}^{-1}$, respectively, while in tap water samples $(n=4)$ the ranges were higher: $0.11-0.32 \mu \mathrm{g} \mathrm{L}^{-1}$ and $0.06-0.17 \mu \mathrm{g} \mathrm{L} \mathrm{L}^{-1}$. Fortunately, in none of the samples the $\mathrm{Tl}$ concentrations exceeded the US EPA maximum permissible concentration of $0.5 \mu \mathrm{g} \mathrm{L} \mathrm{L}^{-1}$.

7.2.9 Alcoholic beverages. Escudero et al. ${ }^{153}$ highlighted for the first time the presence of both $\mathrm{As}^{\mathrm{III}}$ and $\mathrm{As}^{\mathrm{V}}$ as well as organic As in red and white wine. A highly selective preconcentration and speciation technique for $\mathrm{As}^{\mathrm{III}}$ was proposed by using complexation with DDTC and extraction into the ionic liquid, 1-octyl-3-methylimidazolium hexafluorophosphate. Concentrations of $\mathrm{As}^{\mathrm{III}}$ and $\mathrm{As}^{\mathrm{V}}$ ranged from 1.08 to $6.5 \mu \mathrm{g} \mathrm{L}^{-1}$ and 2.1 to $11.2 \mu \mathrm{g} \mathrm{L} \mathrm{L}^{-1}$, respectively; the sum of DMA and MMA was generally less than $0.8 \mu \mathrm{g} \mathrm{L}^{-1}$. The production of quality Brazilian wine is on the increase and it is only to be expected that a targeted authenticity study would appear. Origin determination of 32 Brazilian wines ${ }^{62}$ from eight regions, and vinified using the same protocol, was carried using HR-CS-FAAS. A PCA of the concentrations of only four elements $(\mathrm{K}, \mathrm{Mn}, \mathrm{Rb}$ and $\mathrm{Sr}$ ) represented $85 \%$ of the variance over three components and allowed separation of seven of the regions under study. It has long been known that packaging can have an influence on the concentrations of numerous elements, particularly those food stuffs with a low $\mathrm{pH}$ such as wine. Hopfer $e t$ al. ${ }^{154}$ measured the concentrations of 14 metals using ICP-MS in the same red wine packaged in bag-in-box, or in green wine bottles sealed either under cork or screw cap, all stored at temperatures of $10^{\circ} \mathrm{C}$, $20{ }^{\circ} \mathrm{C}, 40{ }^{\circ} \mathrm{C}$. Significant differences were reported for the concentrations of $\mathrm{Cr}, \mathrm{Cu}, \mathrm{Pb}, \mathrm{Sn}$ and $\mathrm{V}$. The major difference was the amount of Sn leached from the screw cap liners, particularly in those stored at the highest temperature. A matrix-assisted photochemical VG method for the determination of $\mathrm{Hg}$ in alcoholic drinks was demonstrated for use with ICP-MS. ${ }^{53}$ Without the addition of a reducing agent, $\mathrm{Hg}$ vapour was generated from the EtOH-containing matrix and transported into the ICP mass spectrometer with the Ar carrier gas. No interferences were observed from $\mathrm{Co}, \mathrm{Cu}, \mathrm{Fe}, \mathrm{Ni}$ or $\mathrm{Zn}$ when present at 500 times the analyte concentration.

\section{Abbreviations}

$\begin{array}{ll}\text { 2D } & \text { Two dimensional } \\ \text { 3D } & \text { Three dimensional } \\ \text { 5-Br- } & \text { 2-(5-Bromo-2-pyridylazo)-5-(diethyl amino) phenol } \\ \text { PADAP } & \\ \text { AAS } & \text { Atomic absorption spectrometry } \\ \text { AB } & \text { Arsenobetaine } \\ \text { ACGIH } & \text { American Conference of Governmental Industrial } \\ & \text { Hygienists } \\ \text { AES } & \text { Atomic emission spectrometry }\end{array}$

AFS Atomic fluorescence spectrometry

AIP Atomically imprinted polymer

AOAC Association of Official Analytical Chemists

ASE Accelerated solvent extraction

ASU Atomic Spectrometry Update

ATP Adenosine triphosphate

CE Capillary electrophoresis

CPE Cloud point extraction

CRM Certified reference material

CS Continuum source

CSF Cerebrospinal fluid

CV Cold vapour

DDTC Diethyldithiocarbamate

DLLME Dispersive liquid-liquid microextraction

DMA Dimethylarsenic

DNA Deoxyribonucleic acid

DRC Dynamic reaction cell

EDS Energy dispersive spectrometry

EDTA Ethylenediamine tetraacetic acid

EDXRF Energy dispersive X-ray diffraction

EPA Environmental Protection Agency

ES Electrospray

ESI Electrospray ionization

ETAAS Electrothermal atomic absorption spectrometry

EtHg Ethylmercury

EXAFS Extended X-ray absorption fine structure

FAAS Flame atomic absorption spectrometry

FI Flow injection

FT Fourier transform

GC Gas chromatography

GE Gas electrophoresis

GF Graphite furnace

GPx Glutathione peroxidase

HG Hydride generation

HG-AAS Hydride generation atomic absorption spectrometry

HG-FAAS Hydride generation atomic fluorescence

spectrometry

HILIC Hydrophilic interaction liquid

HPLC High performance liquid chromatography

HR High resolution

iAs Inorganic arsenic

IBMK Isobutyl methyl ketone

IC Ion chromatography

ICP Inductively coupled plasma

ICP-AES Inductively coupled plasma atomic emission spectrometry

ICP-MS Inductively coupled plasma mass spectrometry

ICP-QMS Inductively coupled plasma quadrupole mass spectrometry

ID Isotope dilution

IDA Isotope dilution analysis

IE Ion exchange

iHg Inorganic mercury

INAA Instrumental neutron activation analysis

JAAS Journal of Analytical Atomic Spectrometry

kDa kiloDalton

LA Laser ablation

LC Liquid chromatography

LIBS Laser induced breakdown spectroscopy 


\begin{tabular}{|c|c|}
\hline LOD & Limit of detection \\
\hline LOQ & Limit of quantification \\
\hline MALDI & Matrix-assisted laser desorption ionization \\
\hline MC & Multicollector \\
\hline $\mathrm{Me}_{3} \mathrm{Sb}$ & Trimethyl antimony \\
\hline $\mathrm{MeHg}$ & Methyl mercury \\
\hline MIP & Microwave induced plasma \\
\hline MMA & Monomethylarsonic acid \\
\hline MMAv & Monomethylarsinic acid \\
\hline Mpa & Megapascal \\
\hline$M_{\mathrm{r}}$ & Molecular mass \\
\hline MRI & Magnetic resonance imaging \\
\hline MS & Mass spectrometry \\
\hline NEQAS & National External Quality Assessment Scheme \\
\hline NIST & National Institute of Standards and Technology \\
\hline ppb & Parts per billion $\left(10^{-9}\right)$ \\
\hline NMI & National Metrological Institute \\
\hline NMIJ & National Metrological Institute of Japan \\
\hline NTIMS & Negative thermal ionization mass spectrometry \\
\hline OES & Optical emission spectrometry \\
\hline PAGE & Polyacrylamide gel electrophoresis \\
\hline PCA & Principal component analysis \\
\hline PTWI & Provisional tolerable weekly intake \\
\hline REE & Rare earth element \\
\hline $\mathrm{RM}$ & Reference material \\
\hline $\mathrm{RP}$ & Reversed phase \\
\hline RSD & Relative standard deviation \\
\hline SDS & Sodium dodecylsulfate \\
\hline SEC & Size exclusion chromatography \\
\hline SeCys 2 & Selenocystine \\
\hline SEM & Scanning electron microscopy \\
\hline SeMet & Selenomethionein \\
\hline SF & Sector field \\
\hline SIMS & Secondary ion mass spectrometry \\
\hline SNMS & Secondary neutral mass spectrometry \\
\hline SPE & Solid phase extraction \\
\hline SPME & Solid phase microextraction \\
\hline SR & Synchrotron radiation \\
\hline SRM & Standard reference material \\
\hline SR-XAS & $\begin{array}{l}\text { Synchrotron radiation X-ray absorption } \\
\text { spectroscopy }\end{array}$ \\
\hline SR-XRF & Synchrotron radiation X-ray fluorescence \\
\hline TBT & Tributyl tin \\
\hline TOF & Time-of-flight \\
\hline UV & Ultraviolet \\
\hline VG & Vapour generation \\
\hline WD & Wilson's disease \\
\hline XANES & X-ray absorption near-edge structure \\
\hline XAS & X-ray absorption spectroscopy \\
\hline XFM & $\mathrm{X}$-ray fluorescence microscopy \\
\hline XRF & X-ray fluorescence \\
\hline
\end{tabular}

\section{References}

1 A. Taylor, M. P. Day, S. Hill, J. Marshall, M. Patriarca and M. White, J. Anal. At. Spectrom., 2013, 28(4), 425459.
2 M. West, A. T. Ellis, P. J. Potts, C. Streli, C. Vanhoof, D. Wegrzynek and P. Wobrauschek, J. Anal. At. Spectrom., 2012, 27(10), 1603-1644.

3 S. Carter, A. S. Fisher, M. W. Hinds and S. Lancaster, J. Anal. At. Spectrom., 2012, 27(12), 2003-2053.

4 O. T. Butler, W. R. L. Cairns, J. M. Cook and C. M. Davidson, J. Anal. At. Spectrom., 2013, 28(2), 177-216.

5 E. H. Evans, M. Horstwood, J. Pisonero and C. M. M. Smith, J. Anal. At. Spectrom., 2013, 28(6), 779-800.

6 R. Clough, C. F. Harrington, S. J. Hill, Y. Madrid and J. F. Tyson, J. Anal. At. Spectrom., 2013, 28(8), 11531195.

7 K. Kleparnik, Electrophoresis, 2013, 34(1), 70-85.

8 C. H. Latorre, J. A. Mendez, J. B. Garcia, S. G. Martin and R. M. P. Crecente, Anal. Chim. Acta, 2012, 749, 16-35.

9 C. M. Weekley, J. B. Aitken, L. Finney, S. Vogt, P. K. Witting and H. H. Harris, Nutrients, 2013, 5(5), 1734-1756.

10 E. J. Lanni, S. S. Rubakhin and J. V. Sweedler, J. Proteomics, 2012, 75(16), 5036-5051.

11 H. Y. Yan and H. Wang, J. Chromatogr., A, 2013, 1295, 1-15.

12 M. Groessl and C. G. Hartinger, Anal. Bioanal. Chem., 2013, 405(6), 1791-1808.

13 T. R. McClintock, Y. Chen, J. Bundschuh, J. T. Oliver, J. Navoni, V. Olmos, E. V. Lepori, H. Ahsan and F. Parvez, Sci. Total Environ., 2012, 429, 76-91.

14 M. Filella, N. Belzile and Y. W. Chen, Crit. Rev. Environ. Sci. Technol., 2013, 43(2), 162-214.

15 A. O. Sunday, B. A. Alafara and O. G. Oladele, Chem. Speciation Bioavailability, 2012, 24(4), 216-226.

16 S. Miyashita, K. Inagaki, T. Narukawa, Y. B. Zhu, T. Kuroiwa, A. Hioki and K. Chiba, Anal. Sci., 2012, 28(12), 1171-1177.

17 P. Hoet, C. Jacquerye, G. Deumer, D. Lison and V. Haufroid, Clin. Chem. Lab. Med., 2013, 51(4), 839-849.

18 C. E. Sieniawska, L. C. Jung, R. Olufadi and V. Walker, Ann. Clin. Biochem., 2012, 49(4), 341-351.

19 L. Rello, A. C. Lapena, M. Aramendia, M. A. Belarra and M. Resano, Spectrochim. Acta, Part B, 2013, 81, 11-19.

20 M. Resano, M. Aramendia, L. Rello, M. L. Calvo, S. Berail and C. Pecheyran, J. Anal. At. Spectrom., 2013, 28(1), 98-106.

21 G. A. Zachariadis, N. M. Tzollas, M. Nikolaou and E. Rosenberg, Biomed. Chromatogr., 2013, 27(3), 299-305.

22 B. B. Chen, B. Hu, M. He, Q. Huang, Y. Zhang and X. Zhang, J. Anal. At. Spectrom., 2013, 28(3), 334-343.

23 G. C. de Lima, A. C. do Lago, A. A. Chaves, P. S. Fadini and P. O. Luccas, Anal. Chim. Acta, 2013, 768, 35-40.

24 E. Q. Oreste, A. de Jesus, R. M. de Oliveira, M. M. da Silva, M. A. Vieira and A. S. Ribeiro, Microchem. J., 2013, 109, 5-9.

25 J. J. B. Nevado, R. C. R. Martin-Doimeadios, F. J. G. Bernardo, N. R. Farinas and M. J. P. Ropero, Talanta, 2012, 99, 859-864.

26 K. Hayashi, J. Ohsako, T. Nakajima, H. Takanashi and A. Ohki, Bunseki Kagaku, 2012, 61(12), 1073-1077.

27 H. I. Ulusoy, U. Aksoy and M. Akcay, Eur. Food Res. Technol., 2013, 236(4), 725-733.

28 P. H. Liao, S. J. Jiang and A. C. Sahayam, J. Anal. At. Spectrom., 2012, 27(9), 1518-1524. 
29 A. Taylor, S. Branch, M. P. Day, M. Patriarca and M. White, J. Anal. At. Spectrom., 2008, 23(4), 595-646.

30 A. Pineiro, J. Moreda-Pineiro, E. Alonso-Rodriguez, P. Lopez-Mahia, S. Muniategui-Lorenzo and D. PradaRodriguez, Talanta, 2013, 105, 422-428.

31 Y. Y. He, S. Z. Chen, X. R. Zhou and X. Wang, At. Spectrosc., 2012, 33(4), 117-122.

32 L. B. Escudero, R. G. Wuilloud and R. A. Olsina, J. Hazard. Mater., 2013, 244, 380-386.

33 C. Venzago, M. Popp, J. Kovac and A. Kunkel, J. Anal. At. Spectrom., 2013, 28(7), 1125-1129.

34 C. E. R. de Paula, L. F. S. Caldas, D. M. Brum and R. J. Cassella, J. Pharm. Biomed. Anal., 2013, 74, 284-290.

35 A. L. H. Muller, P. A. Mello, M. F. Mesko, F. A. Duarte, V. L. Dressler, E. I. Muller and E. M. M. Flores, J. Anal. At. Spectrom., 2012, 27(11), 1889-1894.

36 W. Guo, S. H. Hu, Y. X. Wang, L. Y. Zhang, Z. C. Hu and J. Y. Zhang, Microchem. J., 2013, 108, 106-112.

37 A. J. Steuerwald, P. J. Parsons, J. G. Arnason, Z. Chen, C. M. Peterson and G. M. B. Louis, J. Anal. At. Spectrom., 2013, 28(6), 821-830.

38 G. L. Donati, R. S. Amais and J. A. Nobrega, Spectroscopy, 2013, 32-35.

39 M. Bernstein, N. M. Desy, A. Petit, D. J. Zukor, O. L. Huk and J. Antoniou, Int. Orthop., 2012, 36(9), 1807-1812.

40 A. W. Newton, L. Ranganath, C. Armstrong, V. Peter and N. B. Roberts, J. Orthop. Res., 2012, 30(10), 16401646.

41 J. Barry, M. Lavigne and P. A. Vendittoli, J. Anal. Toxicol., 2013, 37(2), 90-96.

42 F. Mazoochian, F. Schmidutz, J. Kiefl, A. Fottner, B. Michalke, R. Schierl, P. Thomas and V. Jonsson, Acta Chir. Belg., 2013, 113(2), 123-128.

43 T. P. Cundy and C. P. Kirby, J. Pediatr. Surg., 2012, 47(8), 1506-1511.

44 T. P. Cundy, G. Antoniou, L. M. Sutherland, B. J. C. Freeman and P. J. Cundy, Spine, 2013, 38(7), 564-570.

45 M. F. Gornet, J. K. Burkus, M. L. Harper, F. W. Chan, A. K. Skipor and J. J. Jacobs, Eur. Spine J., 2013, 22(4), 741-746.

46 G. W. Omlor, J. P. Kretzer, J. Reinders, M. R. Streit, T. Bruckner, T. Gotterbarm, P. R. Aldinger and C. Merle, Acta Biomater., 2013, 9(4), 6278-6282.

47 W. Cieslak, K. Pap, D. R. Bunch, E. Reineks, R. Jackson, R. S. Le and S. Wang, Clin. Biochem., 2013, 46(3), 266-270.

48 L. Hao, H. Y. Cheng, J. H. Liu and X. F. Yin, Chem. Res. Chin. Univ., 2012, 33(9), 1957-1963.

49 C. L. Wu, H. Y. Cheng, J. H. Liu, Z. G. Xu and X. F. Yin, Chin. J. Anal. Chem., 2013, 41(3), 349-353.

50 L. F. Espinosa-Cristobal, G. A. Martinez-Castanon, J. P. Loyola-Rodriguez, N. Patino-Marin, J. F. ReyesMacias, J. M. Vargas-Morales and F. Ruiz, J. Nanopart. Res., 2013, 15(6), 12.

51 M. Hadioui, S. Leclerc and K. J. Wilkinson, Talanta, 2013, 105, 15-19.

52 A. Leufroy, L. Noel, D. Beauchemin and T. Guerin, Food Chem., 2012, 135(2), 623-633.
53 Y. Gao, X. H. Peng, Z. M. Shi, R. X. Zhang, X. F. Xia, F. R. Yue and R. Liu, At. Spectrosc., 2012, 33(3), 73-77.

54 L. Husakova, I. Urbanova, J. Sramkova, M. Konecna and J. Bohuslavova, Talanta, 2013, 106, 66-72.

55 J. H. Chen, S. Shahnavas, N. Singh, W. Y. Ong and T. Walczyk, Metallomics, 2013, 5(2), 167-173.

56 K. Miura, K. Yamamoto, A. Yonetani and T. Shirasaki, Bunseki Kagaku, 2013, 62(1), 37-41.

57 S. X. Li, F. Y. Zheng, Y. C. Li, T. S. Cai and J. Z. Zheng, J. Agric. Food Chem., 2012, 60(47), 11691-11695.

58 F. Gerondi and M. A. Z. Arruda, Talanta, 2012, 97, 395-399.

59 T. Lech and D. Dudek-Adamska, J. Anal. Toxicol., 2013, 37(2), 97-101.

60 A. N. Zacharia, A. S. Zhuravlev, A. N. Chebotarev and M. V. Arabadgi, J. Appl. Spectrosc., 2013, 79(6), 949-954.

61 J. R. Marval-Leon, F. Camara-Martos, F. Perez-Rodriguez, M. A. Amaro-Lopez and R. Moreno-Rojas, FoodAnal. Methods, 2012, 5(5), 1054-1061.

62 W. Boschetti, R. T. Rampazzo, M. B. Dessuy, M. G. R. Vale, A. D. Rios, P. Hertz, V. Manfroi, P. G. Celso and M. F. Ferrao, Talanta, 2013, 111, 147-155.

63 T. Ren, L. J. Zhao, J. Cao and R. G. Zhong, Spectrosc. Spectral Anal., 2012, 32(9), 2566-2571.

64 J. F. Rego, A. Virgilio, J. A. Nobrega and J. A. G. Neto, Talanta, 2012, 100, 21-26.

65 N. Ozbek and S. Akman, J. Agric. Food Chem., 2013, 61(20), 4816-4821.

66 N. Ozbek and S. Akman, Food Chem., 2013, 138(1), 650-654.

67 M. Fechetia, A. L. Tognon and M. da Veiga, Spectrochim. Acta, Part B, 2012, 71-72, 98-101.

68 L. N. Santos, M. H. Gonzalez, M. F. Moura, G. L. Donati and J. A. Nobrega, Talanta, 2012, 97, 285-290.

69 V. Cerveny, M. Horvath and J. A. C. Broekaert, Microchem. J., 2013, 107, 10-16.

70 A. Tyburska and K. Jankowski, J. Pharm. Biomed. Anal., 2013, 74, 268-272.

71 J. P. Lu, F. W. Tan, Q. Tang and T. C. Jiang, Chem. Res. Chin. Univ., 2013, 29(1), 26-29.

72 L. L. Chaparro, L. Ferrer, V. Cerda and L. O. Leal, Anal. Bioanal. Chem., 2012, 404(5), 1589-1595.

73 J. Cui, Y. B. Xiao, L. Dai, X. H. Zhao and Y. Wang, Food Anal. Methods, 2013, 6(2), 370-379.

74 D. Olivares, M. Bravo, J. Feldmann, A. Raab, A. Neaman and W. Quiroz, J. AOAC Int., 2012, 95(4), 1176-1182.

75 W. B. Zhang, X. A. Yang, Y. P. Dong and J. J. Xue, Anal. Chem., 2012, 84(21), 9199-9207.

76 J. Kuta, J. Machat, D. Benova, R. Cervenka and T. Koristkova, Cent. Eur. J. Chem., 2012, 10(5), 1475-1483.

77 G. R. Wohl, D. R. Chettle, A. Pejovic-Milic, C. Druchok, C. E. Webber, J. D. Adachi and K. A. Beattie, Bone, 2013, 52(1), 63-69.

78 R. R. Martin, S. Naftel, S. Macfie, K. Jones and A. Nelson, Appl. Phys. A: Mater. Sci. Process., 2013, 111(1), 23-29.

79 M. Szczerbowska-Boruchowska, X-Ray Spectrom., 2012, 41(5), 328-337.

80 I. B. Magana, P. Adhikari, M. C. Smalley, S. E. Eklund and D. P. O'Neal, Anal. Methods, 2013, 5(12), 3148-3151. 
81 E. Morena-Gordaliza, D. Esteban-Fernandez, C. Giesen, K. Lehmann, A. Lazaro, A. Tejedor, C. Scheler, B. Canas, N. Jakubowski, M. W. Linscheid and M. M. GomezGomez, J. Anal. At. Spectrom., 2012, 27(9), 1474-1483.

82 C. Arnaudguilhem, K. Bierla, L. Ouerdane, H. Preud'homme, A. Yiannikouris and R. Lobinski, Anal. Chim. Acta, 2012, 757, 26-38.

83 K. M. Davies, D. J. Hare, V. Cottam, N. Chen, L. Hilgers, G. Halliday, J. F. B. Mercer and K. L. Double, Metallomics, 2013, 5(1), 43-51.

84 A. Taylor, S. Branch, M. P. Day, M. Patriarca and M. White, J. Anal. At. Spectrom., 2011, 26(4), 653-692.

85 A. Taylor, M. P. Day, J. n. Marshall, M. Patriarca and M. White, J. Anal. At. Spectrom., 2012, 27(4), 537-576.

86 N. Solovyev, A. Berthele and B. Michalke, Anal. Bioanal. Chem., 2013, 405(6), 1875-1884.

87 B. Michalke, M. Lucio, A. Berthele and B. Kanawati, Anal. Bioanal. Chem., 2013, 405(7), 2301-2309.

88 A. Takeuchi, A. Namera, Y. Kawasumi, T. Imanaka, N. Sakui, H. Ota, Y. Endo, K. Sumino and G. Endo, J. Occup. Health, 2012, 54(6), 434-440.

89 S. S. de Souza, A. D. Campiglia and F. Barbosa, Anal. Chim. Acta, 2013, 761, 11-17.

90 B. D. Kerger, R. Gerads, H. Gurleyuk, K. A. Thuett, B. L. Finley and D. J. Paustenbach, Toxicol. Environ. Chem., 2013, 95(4), 687-708.

91 B. D. Kerger, B. E. Tvermoes, K. M. Unice, B. L. Finley, D. J. Paustenbach and D. A. Galbraith, Toxicol. Environ. Chem., 2013, 95(4), 709-718.

92 M. Aramendia, L. Rello, M. Resano and F. Vanhaecke, J. Anal. At. Spectrom., 2013, 28(5), 675-681.

93 B. Wu and J. S. Becker, Int. J. Mass Spectrom., 2012, 323, 34-40. 94 J. Lear, D. J. Hare, F. Fryer, P. A. Adlard, D. I. Finkelstein and P. A. Doble, Anal. Chem., 2012, 84(15), 6707-6714.

95 O. Reifschneider, C. A. Wehe, K. Diebold, C. Becker, M. Sperling and U. Karst, J. Anal. At. Spectrom., 2013, 28(7), 989-993.

96 K. Stepankova, K. Novotny, M. V. Galiova, V. Kanicky, J. Kaiser and D. W. Hahn, Spectrochim. Acta, Part B, 2013, 81, 43-49.

97 D. Herwartz, T. Tutken, K. P. Jochum and P. M. Sander, Geochim. Cosmochim. Acta, 2013, 103, 161-183.

98 M. J. Kohn, J. Morris and P. Olin, J. Archaeol. Sci, 2013, 40(4), 1689-1699.

99 J. Bianga, E. Govasmark and J. Szpunar, Anal. Chem., 2013, 85(4), 2037-2043.

100 K. L. Moore, C. R. Hawes, S. P. McGrath, F. J. Zhao and C. R. M. Grovenor, Surf. Interface Anal., 2013, 45(1), 309-311.

101 C. C. Chang, C. N. Chen, W. J. Lin, T. Y. Lo, S. L. Lei and F. D. Mai, Surf. Interface Anal., 2013, 45(1), 248-250.

102 F. Draude, S. Galla, A. Pelster, J. Tentschert, H. Jungnickel, A. Haase, A. Mantion, A. F. Thunemann, A. Taubert, A. Luch and H. F. Arlinghaus, Surf. Interface Anal., 2013, 45(1), 286289.

103 R. R. Sidaginamala, T. J. Joyce, J. K. Lord, R. Jefferson, P. G. Blain, A. V. F. Nargol and D. J. Langton, Bone Joint Res., 2013, 2, 84-95.
104 P. M. Roos, O. Vesterberg, T. Syversen, T. P. Flaten and M. Nordberg, Biol. Trace Elem. Res., 2013, 151(2), 159-170.

105 B. W. Chen, F. L. Cao, C. G. Yuan, X. F. Lu, S. W. Shen, J. Zhou and X. C. Le, Anal. Bioanal. Chem., 2013, 405(6), 1903-1911.

106 T. Litwin, G. Gromadzka, G. M. Szpak, K. Jablonka-Salach, E. Bulska and A. Czlonkowska, J. Neurol. Sci., 2013, 329(1-2), 55-58.

107 I. M. Kempson and W. M. Skinner, Biol. Trace Elem. Res., 2012, 150(1-3), 10-14.

108 H. M. Liu, Anal. Methods, 2013, 5(4), 897-903.

109 P. Lovreglio, M. N. D'Errico, P. De Pasquale, M. E. Gilberti, I. Drago, L. Panuzzo, A. Lepera, R. Serra, F. Ferrara, A. Basso, P. Apostoli and L. Soleo, Med. Lav., 2012, 103(5), 372-381.

110 M. Molin, T. A. Ydersbond, S. M. Ulven, M. Holck, L. Dahl, J. J. Sloth, D. Fliegel, W. Goessler, J. Alexander and H. M. Meltzer, Food Chem. Toxicol., 2012, 50(7), 2462-2472.

111 H. M. Liu, J. K. Jiang and Y. H. Lin, Anal. Lett., 2012, 45(14), 2096-2107.

112 N. J. Pullan, V. Thurston and S. Barber, Ann. Clin. Biochem., 2013, 50(3), 267-270.

113 A. E. Dolphin, S. J. Naftel, A. J. Nelson, R. R. Martin and C. D. White, J. Archaeol. Sci., 2013, 40(4), 1778-1786.

114 H. Gonzalez-Iglesias, M. L. Fernandez-Sanchez, J. LopezSastre and A. Sanz-Medel, Electrophoresis, 2012, 33(15), 2407-2415.

115 M. L. Fernandez-Sanchez, R. R. D. St Remy, H. G. Iglesias, J. B. Lopez-Sastre, B. Fernandez-Colomer, D. Perez-Solis and A. Sanz-Medel, Microchem. J., 2012, 105, 108-114.

116 J. Wu, D. J. Liu, Q. Xie and J. Y. Wang, PLoS One, 2012, 7(12), 7.

117 T. Fujimura, T. Terachi, M. Funaba and T. Matsui, Metallomics, 2012, 4(8), 847-850.

118 M. Wilhelm, J. Wittsiepe, M. Seiwert, A. Hunken, K. Becker, A. Conrad, C. Schulz and M. Kolossa-Gehring, Int. J. Hyg. Environ. Health, 2013, 216(2), 163-169.

119 U. Darsow, M. Fedorov, U. Schwegler, D. Twardella, K. H. Schaller, R. Habernegg, H. Fromme, J. Ring and H. Behrendt, Contact Dermatitis, 2012, 67(6), 351-358.

120 G. Hermann, P. Heffeter, T. Falta, W. Berger, S. Hann and G. Koellensperger, Metallomics, 2013, 5(6), 636-647.

121 Y. Kitamura, K. Usuda, H. Shimizu, K. Fujimoto, R. Kono, A. Fujita and K. Kono, Biol. Trace Elem. Res., 2012, 150(1-3), 322-327.

122 J. Gomez-Espina, E. Blanco-Gonzalez, M. Montes-Bayon and A. Sanz-Medel, J. Anal. At. Spectrom., 2012, 27(11), 1949-1954.

123 F. Gagne, P. Turcotte and C. Gagnon, Anal. Bioanal. Chem., 2012, 404(6-7), 2067-2072.

124 C. Rigo, M. Roman, I. Munivrana, V. Vindigni, B. Azzena, C. Barbante and W. R. L. Cairns, Burns, 2012, 38(8), 11311142.

125 R. Moradkhani, A. Rouhollahi, H. Shirkhanloo and J. B. Ghasemi, J. Chin. Chem. Soc., 2013, 60(5), 481-487.

126 D. Lariviere, S. Y. Tolmachev, V. Kochermin and S. Johnson, J. Environ. Radioact., 2013, 121, 98-103. 
127 D. S. Urgast, S. Hill, I. S. Kwun, J. H. Beattie, H. GoenagaInfante and J. Feldmann, Metallomics, 2012, 4(10), 10571063.

128 R. V. Hedegaard, I. Rokkjaer and J. J. Sloth, Anal. Bioanal. Chem., 2013, 405(13), 4429-4435.

129 K. X. Bu, J. V. Cizdziel and L. Reidy, Microchem. J., 2013, 106, 244-249.

130 A. H. Petursdottir, H. Gunnlaugsdottir, H. Jorundsdottir, A. Mestrot, E. M. Krupp and J. Feldmann, Anal. Bioanal. Chem., 2012, 404(8), 2185-2191.

131 L. R. Drennan-Harris, S. Wongwilawan and J. F. Tyson, J. Anal. At. Spectrom., 2013, 28, 259-265.

132 D. J. Kutscher, A. Sanz-Medel and J. Bettmer, Metallomics, 2012, 4(8), 807-813.

133 P. R. Aranda, L. Colombo, E. Perino, I. E. De Vito and J. Raba, X-Ray Spectrom., 2013, 42(2), 100-104.

134 H. I. Ulusoy, O. Yilmaz and R. Gurkan, Food Chem., 2013, 139(1-4), 1008-1014.

135 V. Fekete, E. Deconinck, F. Bolle and J. Van Loco, Food Addit. Contam., Part A, 2012, 29(8), 1322-1333.

136 W. W. K. Wong, S. W. C. Chung, B. T. P. Chan, Y. Y. Ho and Y. Xiao, Food Chem. Toxicol., 2013, 51, 379-385.

137 Q. Jiang, J. Wang, M. Li, X. X. Liang, G. W. Dai, Z. K. Hu, J. Wen, Q. Huang and Y. H. Zhang, Food Addit. Contam., Part A, 2013, 30(4), 698-704.

138 D. G. Jiang, J. Yang, S. Zhang and D. J. Yang, Biomed. Environ. Sci., 2012, 25(3), 267-271.

139 L. R. da Cunha, T. H. M. da Costa and E. D. Caldas, Biol. Trace Elem. Res., 2013, 151(1), 30-37.

140 F. Cordeiro, I. Baer, P. Robouch, H. Emteborg, S. Z. Can, A. Krata, M. Zampella, C. R. Quetel, R. Hearn and B. De la Calle, Food Addit. Contam., Part A, 2013, 30(4), 678686.

141 D. Sullivan, R. Zywicki and D. Dowell, J. AOAC Int., 2013, 96(3), 493-496.

142 C. Er, B. F. Senkal and M. Yaman, Food Chem., 2013, 137(1-4), 55-61.

143 F. Rey-Crespo, M. Miranda and M. Lopez-Alonso, Food Chem. Toxicol., 2013, 55, 513-518.

144 R. Hernandez-Martinez and I. Navarro-Blasco, Food Control, 2013, 30(2), 423-432.

145 A. Imai, A. Otaka, S. Nakamura, M. Kadokura, T. Suzuki and I. Nakai, Journal of the Japanese Society for Food Science and Technology-Nippon Shokuhin Kagaku Kogaku Kaishi, 2012, 59(7), 338-347.

146 I. J. Cindric, I. Krizman, M. Zeiner, S. Kampic, G. Medunic and G. Stingeder, Food Chem., 2012, 135(4), 2675-2680.

147 P. Krystek, P. Favaro, P. Bode and R. Ritsema, Talanta, 2012, 97, 83-86.
148 V. Sele, H. Amlund, M. H. G. Berntssen, J. A. Berntsen, K. Skov and J. J. Sloth, Anal. Bioanal. Chem., 2013, 405(15), 5179-5190.

149 K. Julshamn, B. M. Nilsen, S. Frantzen, S. Valdersnes, A. Maage, K. Nedreaas and J. J. Sloth, Food Addit. Contam., Part B, 2012, 5(4), 229-235.

150 E. Sugar, E. Tatar, G. Zaray and V. G. Mihucz, Microchem. J., 2013, 107, 131-135.

151 S. D. Conklin and P. E. Chen, Food Addit. Contam., Part A, 2012, 29(8), 1272-1279.

152 S. Garbos and D. Swiecicka, Food Addit. Contam., Part A, 2012, 29(11), 1810-1819.

153 L. B. Escudero, E. M. Martinis, R. A. Olsina and R. G. Wuilloud, Food Chem., 2013, 138(1), 484-490.

154 H. Hopfer, J. Nelson, A. E. Mitchell, H. Heymann and S. E. Ebler, J. Anal. At. Spectrom., 2013, 28, 1288-1291.

155 T. Lech, J. Anal. Toxicol., 2013, 37(4), 222-226.

156 R. Zhang, H. A. Ma, H. L. Li, J. Xu, J. P. Zhang, Y. Zhang and Q. T. Wang, Clin. Chim. Acta, 2013, 420, 146-149.

157 D. E. B. Fleming, M. R. Gherase and M. Anthonisen, X-Ray Spectrom., 2013, 42(4), 299-302.

158 T. Nguyen, J. Ostergaard, S. Sturup and B. Gammelgaard, Int. J. Pharm., 2013, 449(1-2), 95-102.

159 C. B. Hu, Y. L. Wang, Y. Fu, J. X. Sun, M. Y. Deng and X. Z. Xiang, Polym. Bull., 2012, 69(5), 511-525.

160 R. Agarwal, D. Virmani, M. Jaipal, S. Gupta, M. J. Sankar, S. Bhatia, A. Agarwal, V. Devgan, A. Deorari, V. K. Paul, G. S. Toteja and L. B. W. M. S. Investigators, Neonatology, 2013, 103(1), 54-59.

161 S. P. McCormick, M. Chakrabarti, A. L. Cockrell, J. Park, L. S. Lindahl and P. A. Lindahl, Metallomics, 2013, 5(3), 232-241.

162 K. Isama, T. Kawakami and T. Nishimura, J. Pharm. Soc. Jpn., 2012, 132(8), 959-968.

163 I. N. Pasias, N. S. Thomaidis and E. A. Piperaki, Microchem. J., 2013, 108, 1-6.

164 S. Y. Ng, A. Zou, L. P. Sim, Y. Ding, K. L. Yuen, R. Y. C. Shin and T. K. Lee, Int. J. Mass Spectrom., 2012, 321, 19-24.

165 S. Akamatsu, N. Yoshioka and T. Mitsuhashi, Food Addit. Contam., Part A, 2012, 29(11), 1696-1700.

166 D. Mendil, J. Food Sci., 2012, 77(9), T181-T186.

167 A. Placido, R. Kupers, P. Paiga, J. Magalhaes, H. P. A. Nouws, C. Delerue-Matos and M. Oliveira, J. Food Compos. Anal., 2012, 27(1), 14-20.

168 M. G. A. Korn, M. A. B. Guida, J. T. P. Barbosa, E. A. Torres, A. P. Fernandes, J. C. C. Santos, K. D. F. Dantas and J. A. Nobrega, Food Anal. Methods, 2013, 6(3), 872-880.

169 J. S. F. Pereira, L. S. F. Pereira, L. Schmidt, C. M. Moreira, J. S. Barin and E. M. M. Flores, Microchem. J., 2013, 109, 29-35. 